\title{
Mirella Amalia Mostoni
}

Conhece-te a ti mesmo

Dissertação apresentada como requisito parcial para a obtenção do grau de mestre Mestrado em Poéticas Visuais Escola de Comunicações e Artes Orientador: Prof.Dr. Geraldo de Souza Dias Filho

São Paulo, 2006 


\section{Conhece-te a ti mesmo}

Uma poética composta por uma série de objetos-oráculo e uma dissertação a respeito de sua gênese, seu processo criativo e seu lugar no contexto contemporâneo de recepção. 
Banca examinadora: 
À minha mãe.

Ao meu pai. 


\section{RESUMO}

Os objetos artísticos do Conhece-te a ti mesmo apresentam-se como oráculos, assumindo na poética e na relação estabelecida com o espectador as conexões de sentido pertencentes a esse termo e a essa condição.

Na parte dissertativa é primeiro apresentada uma investigação sobre o processo criativo desses objetos, os métodos heurísticos utilizados, as influências recebidas e as afinidades com outros trabalhos artísticos.

Num segundo momento estuda-se como a metáfora oracular e os procedimentos utilizados na elaboração dos trabalhos podem situar-se nas questões contemporâneas da recepção.

Na terceira etapa da dissertação reflete-se sobre as semelhanças da poética proposta com o conceito de arte exposto por Nietzsche no texto $O$ Nascimento da Tragédia, as influências dessa obra na gênese da poética e as conseqüências dessa escolha para a recepção e o processo de criação. 


\begin{abstract}
The artistic object of Know Thyself present themselves as oracles, assuming in the poetical and the relation estabilished with spectator connections of meaning pertaining to this term and this condition.
\end{abstract}

In the dissertation part, first is presented an inquiry on creative process of these objects, the heuristic methods used, the received influences and the affinities with other artistic work.

In a second moment, Formulate Thyself, is studied how the oracular metaphor and the procedures used in elaboration of these work may be take place in contemporaries questions about reception.

In the third chapter is reflected on the similarities of the poetical proposal with the concept of art displayed by Nietzsche in Birth of Tragedy, the influences of this text on the genesis of poetical and the consequences of this choice for reception and process of creation. 


\section{Palavras-chave:}

objeto; monotipia; palavra; oráculo; recepção; beleza. 


\section{SUMÁRIO}

1. Introdução..........................................11

2. Imagens dos trabalhos..........................25

3. $\quad$ Conhece-te a ti mesmo.............................48

4. Formula-te a ti mesmo..........................113

5. $\quad$ O Nascimento da Tragédia..................151

6. Conclusão ...........................................184

7. Bibliografia.......................................187

8. Lista das imagens..............................194 
"O ser humano internamente rico

vive numa sala de espelhos"

Rüdiger Safranski 


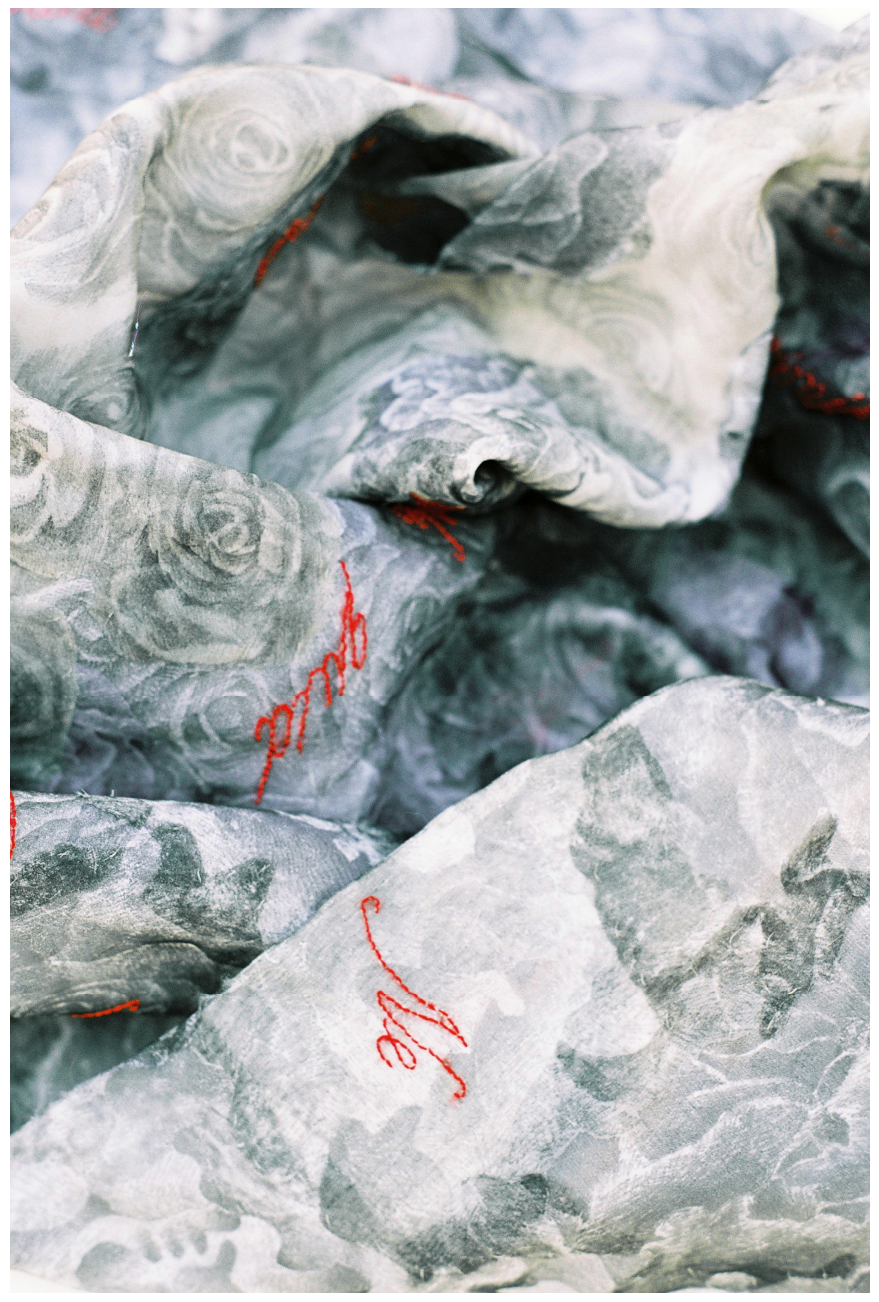


Introdução

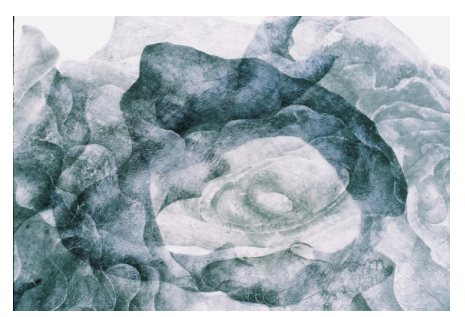




\section{A origem da idéia}

Gnothi se auton ${ }^{1}$

Homo sum; humani nihil a me alienum puto ${ }^{2}$.

Terêncio

Diante da antiga sentença latina Victor Hugo teve uma revelação: "Homo sum. Essa palavra de um poeta resume toda a poesia" ${ }^{3}$.

O escritor lê na frase de Terêncio a possibilidade da criação artística constituir um meio de compreensão e redenção humana. O sentido da frase é ambíguo, mas Hugo, num trecho de seu livro no qual discorre sobre o gênio, opta por dar-lhe um significado de superação da problemática condição do homem, oscilante entre os extremos da genialidade e da miséria, mediante a criação artística.

A emoção transmitida pelo texto de Hugo provoca-me por sua vez minha própria iluminação, porém como chave diferente para uma outra solução.

Já existia a intenção de elaborar um trabalho que proporia em seu título o antigo desafio admoestatório do templo de Apolo em Delfos. Contudo, o oráculo não ofereceria resposta alguma: ainda estava ausente a palavra do objeto artístico.

\footnotetext{
1 "Conhece-te a ti mesmo". Inscrição em grego localizada no templo de Apolo em Delfos. Em latim, Nosce te ipsum.

2 "Sou Homem; e nada do que é humano me é estranho". Terêncio, poeta latino (185-159 a.C.).

${ }^{3}$ Victor HUGO. William Shakespeare, p.206. ( Besançon ,1802 - Paris ,1885).
} 
Eis que se unem as três sentenças numa iluminação. A essência da poesia que a condição humana pode exprimir pronuncia-se como resposta ambígua ao espectador que consulta o oráculo: Homo sum. Irrompe a palavra no objeto artístico.

Forma-se gradativamente a concepção deste mestrado. À poética de objetos construídos com organdi costurado que reúne as linguagens do desenho, da monotipia e da escultura junta-se a escrita por meio do bordado ou do desenho formando as três séries de oráculos e sua metáfora da recepção. 


\section{A evolução da idéia como problema teórico}

São empregadas na poética principalmente duas frases carregadas de cultura e história. Sou homem; nada do que é humano me é estranho não remete apenas à filosofia da antigüidade clássica mas também à estética do século XIX expressa nas palavras de Victor Hugo, as quais encontram seu pano de fundo na estética de Hegel ${ }^{4}$.

Para esse filósofo a arte deveria efetivar o mote de Terêncio fazendo seu espectador entrar em contato com a condição humana, em seus aspectos tanto elevados quanto miseráveis, para formar uma consciência do mundo "interior e exterior, como se fora um objeto no qual ele reconhece o seu próprio si-mesmo (Selbst)" 5 .

Pela via de sua gênese, Conhece-te a ti mesmo também termina por reportar-se às questões da autoconsciência características da estética do século XIX. Esta antiga sentença é, por um lado, herdeira de um pensamento filosófico socrático-platônico que se encaminha para o conhecimento racional da verdade e, por outro, mediante a sua origem délfica, ressurge nos conceitos estéticos do primeiro Nietzsche.

Em O Nascimento da Tragédia são desenvolvidas determinadas idéias sobre a arte por meio da figura de Apolo, deus do oráculo de Delfos, plasmador das artes visuais e do princípio de individuação da personalidade, que reúne em si "ao lado da necessidade estética da beleza, a exigência do conhece-te a ti mesmo" 6 .

A opção da poética apresenta afinidades visíveis com Apolo: o mundo da representação, a beleza que encobre a trágica sentença oracular, a presença da palavra como instrumento de reflexão e contato consigo próprio na consulta ao oráculo. Neste caso, na dialética estabelecida com o trabalho artístico.

\footnotetext{
${ }^{4}$ Shakespeare foi escrito e publicado em 1864-5. Os Cursos de Estética foram ministrados por Hegel no período de 1818 a 1829 e publicados em 1842.

${ }^{5}$ Georg Wilhelm Friedrich HEGEL. Cursos de Estética, vol. I. pp.47-48. (Stuttgart, 1770- Berlim, 1831).

${ }^{6}$ Friedrich NIETZSCHE. O Nascimento da Tragédia,p.40. (Rökken, 1844- Weimar, 1900).
} 
Todavia, a escolha do título Conhece-te a ti mesmo não quer levar a se supor que o assunto tratado reenvie a idéias sobre a obra de arte como manifestação da verdade, autoconhecimento e consciência da totalidade tal como descritas anteriormente.

Neste ponto tomam forma dois problemas teóricos.

Embora se assumam e se investiguem aspectos dessa herança seria errôneo interpretar os oráculos como frutos nostálgicos de uma estética anacrônica, desligados das questões contemporâneas da arte. $O$ contexto no qual a obra decididamente se insere reformula os conceitos de beleza, arte como elevação e redenção do homem. É no modo de recepção hodierno que esta poética será situada.

Os oráculos do Conhece-te a ti mesmo metaforizam a relação entre espectador e obra. Transpõem para uma imagem poética a conexão proposta por toda obra de arte: uma dialética de perguntas, respostas, hipóteses e novas perguntas - tanto as que são trazidas pelo espectador quanto as que ele encontra na própria obra - que se pode estabelecer entre um indivíduo que indaga e uma alteridade que responde de forma plurívoca ${ }^{7}$.

O segundo problema seria dar excessivo peso à aparente contradição entre os significados que acompanham o título elegido (o autoconhecimento socrático que confia à razão e à reflexão o poder de modificar o viver) e o pensamento nietzscheano em geral e sobre a arte. A dissertação evidentemente não tem por objetivo resolver tal embate filosófico, mas reportar-se aos pontos em comum da poética que alimentam a criação e a reflexão com o Nascimento da Tragédia, que são tanto apolíneos quanto dionisíacos, e inserir-se como produção artística no jogo dos pólos opostos complementares ${ }^{8}$.

\footnotetext{
${ }^{7}$ As questões dos dois últimos parágrafos são tratadas no terceiro capítulo, Formula-te a ti mesmo, sobre recepção.

${ }^{8}$ Essas questões são tratadas no segundo capítulo, O Nascimento da Tragédia.
} 
Aqui se evidencia que, nas palavras de Sandra Rey, "toda obra contém em si mesma a sua dimensão teórica" ${ }^{9}$. Contudo, embora corroborando tal postura, Zamboni sugere a possibilidade de inúmeras vias por onde pode encaminhar-se a pesquisa ao colocar que ela só existe dentro do quadro teórico no qual se projeta ${ }^{10}$.

Eleger certas teorias e não outras, fazer certas perguntas e não outras significa permitir-me uma leitura dentre as muitas possíveis das questões que me parecem as mais prementes da minha praxis. Tal leitura muito provavelmente não será a principal nem a melhor, mas é a tentativa de me reconhecer em determinado contexto artístico, teórico e histórico, colocando-me como autora e testemunha do meu trabalho ${ }^{11}$.

\footnotetext{
${ }^{9}$ Sandra REY. Notas sobre Metodologia em Artes Plásticas. p.305.

${ }^{10}$ Sílvio Perini ZAMBONI. A Pesquisa em Arte. p.78.

${ }^{11}$ Sandra REY.Da Prática à Teoria: Três Instâncias Metodológicas sobre a Pesquisa em Poéticas Visuais.p.84.
} 


\section{A pesquisa poética}

O que se entende por "pesquisa em arte com ênfase em Poéticas Visuais?".

Conforme Rey é uma definição que:

"(...) delimita o campo do artista-pesquisador que orienta sua pesquisa a partir do processo de instauração do seu trabalho assim como a partir das questões teóricas suscitadas pela sua prática" ${ }^{12}$.

Nesse campo não se encontra descrito especificamente pelos artistas um "problema" da pesquisa plástica. Na introdução à tese de doutoramento de Carmela Gross lê-se que a artista não se vê movida por um problema objetivamente colocado:

"(...) no plano do sensível não existem dados antecipatórios que se formulam em hipóteses e concluem pela certeza demonstrada" ${ }^{13}$.

A artista aproxima o "problema" à idéia de uma "nova pergunta", pertencente "à ordem do invisível", cuja resposta, a pesquisa plástica, se faz visível de forma concreta, desvelando totalmente a pergunta apenas nesse momento final ${ }^{14}$.

Regina Silveira consolida essa postura e aprofunda-se na maneira do artista tratar seu texto. Sendo para ela a pesquisa "investigação em arte" e assumindo o ponto de vista anterior de que só há arte quando há perguntas, é justamente a partir delas que sintetiza o conceito da pesquisa em arte como uma questão de "grau de prospecção (e risco)", de alta exigência no âmbito acadêmico ${ }^{15}$.

Em se tratando então de uma específica metodologia de pesquisa em artes plásticas, temos, destacadas por Rey, suas principais características de diferenciação: na

\footnotetext{
${ }^{12}$ Ibidem.p. 82.

${ }^{13}$ Maria do Carmo Gross NITSCHE. Pintura/Desenho.p.01.

${ }^{14}$ Maria do Carmo Gross NITSCHE. Op.Cit. p.01.

${ }^{15}$ Regina SILVEIRA. Produção Artística e Pesquisa: Situação Atual. .p.25-27.
} 
arte o objeto de estudo do artista-pesquisador é, primeiro, produzido por ele próprio e, segundo, é produzido concomitantemente à pesquisa teórica ${ }^{16}$.

Outra importante característica, assinalada desta vez por Regina Silveira, é que em arte o conceito mental não se encontra isolado da esfera de sua concretização. $O$ fazer é também pensamento ${ }^{17}$.

A partir dessas especificidades da pesquisa em arte Zamboni estabelece para esse específico desenvolvimento conjugado dos dois tipos de pensamento um critério valioso: a expectativa do artista. $\mathrm{O}$ autor a avalia como um elemento mais relacionado ao processo do trabalho artístico do que com a teoria, critério onde são reconhecidas as peculiaridades da pesquisa em arte, a qual não assume a rigorosa forma científica, apresentando-se como "desejo e expectativa do que poderá acontecer em termos de resultado final" 18 .

A expectativa deste trabalho é a de que os objetos se apresentem como diferentes formas de oráculos, todos oferecendo respostas que, embora nem sempre iguais, se equivalham na ambigüidade tipicamente oracular, conduzindo à idéia de que a procura pelo objeto de arte encerra em si uma pergunta - inconsciente ou não - do espectador, a qual é por ele encontrada na própria obra ${ }^{19}$.

O conjunto das obras requer do espectador a procura de palavras e sentenças não evidentes mediante a investigação de sua aparência. O desejo que se revela em cada uma delas é o de criar sentidos por meio da sequiência formada pelo título do conjunto -Conhece-te a ti mesmo --, os títulos individuais das obras -- Fendas Oraculares;

\footnotetext{
${ }^{16}$ Sandra REY.Op.Cit. p.304.

${ }^{17}$ Regina SILVEIRA.Op.Cit. p.27. Grifo da autora.

${ }^{18} \mathrm{O}$ autor não discute a qualidade da produção artística, mas a da pesquisa teórica. Além do já citado, Zamboni elabora outros três critérios de qualidade da pesquisa. O primeiro e principal é a identificação e clareza do problema de pesquisa desde o início até as expectativas do artista frente aos resultados de seu trabalho e a reação de seu público. O próximo é aquele no qual se individua a consciência com a qual o artista escolhe e opera seu referencial teórico e a clareza que demonstra ao enquadrar seu trabalho nas teorias escolhidas e nas manifestações artísticas a ele relacionadas. O terceiro é a qualidade e pertinência da bibliografia. Sílvio Perini ZAMBONI.Op.Cit. p.80-81.

${ }^{19}$ Conforme observação em aula da Profa. Dra. Mônica Tavares.
} 
Oráculos Portáteis; Tautologias e Ne Quid Nimis -- e as respostas oferecidas pelos oráculos. 


\section{A pesquisa teórica}

O capítulo inicial, Conhece-te a ti mesmo, volta-se para a observação dos trabalhos realizados, tentando-se, como alude o título, compreender os processos mentais que decidem o encaminhamento dado à criação. Por meio de uma minuciosa descrição dos materiais utilizados, dos procedimentos e da aparência final das obras busca-se analisar e refletir sobre três aspectos do trabalho artístico.

Examina-se primeiro sobre que raízes constrói-se a poética do Conhece-te a ti mesmo, fundamentando-se a análise nas influências recebidas das quais se alimenta, nas indagações e procedimentos que a produziram e como gradativamente os resultados ganharam autonomia como obra.

Num segundo momento examinam-se as etapas do processo criativo e os métodos heurísticos de criação pelos quais passou a elaboração de cada trabalho ${ }^{20}$, processo de grande valor para atingir uma consciência mais ampla das origens e das escolhas realizadas.

Por fim, dada a importância da palavra para este trabalho, trata-se de sua manifestação nos oráculos como elemento gráfico e como portadora de significações, já que nas peças são bordados ou desenhados motes clássicos ${ }^{21}$.

\footnotetext{
${ }^{20}$ Para essa análise são essenciais os conceitos dos autores Plaza e Tavares. Cf. Julio PLAZA e Mônica B. TAVARES. Processos Criativos com os Meios Eletrônicos: Poéticas Digitais. Mais especificamente o capítulo 4, O Processo Criativo, pp.63-83 e o capítulo 5, Os Métodos Heurísticos de Criação, pp.87-116. No decorrer do capítulo também está presente a sustentação de outros autores que tratam do processo criativo: DORFLES, DUFRENNE, LANGER, SARTRE, VALÉRY.

${ }^{21}$ Trata-se da palavra procedendo da pesquisa formal, artística e histórica realizada por Butor, das observações de Barthes sobre a escrita nas artes plásticas e especificamente na obra de alguns artistas e das contribuições feitas por Panofsky e Marin sobre o uso de uma antiga sentença latina na pintura $O s$ Pastores da Arcádia, de Poussin. Cf. Michel BUTOR, Les Mots Dans la Peinture; Roland BARTHES, $O$ Óbvio e o Obtuso; Erwin PANOFSKY, Significado Nas Artes Visuais e Louis MARIN, Sublime Poussin. Autores de apoio para o assunto: DIAS, PEREIRA, SARTRE.
} 
De forma geral, o primeiro capítulo tenta elaborar o texto como um reflexo ampliado da pesquisa poética, onde a palavra não ilustra nem explica o trabalho, mas é instrumento para a compreensão dos elementos que o compõem.

O segundo capítulo, Formula-te a ti mesmo, examina a recepção da metáfora do oráculo $^{22}$.

Para se atingir esse objetivo o tema desdobra-se em duas partes. Na primeira trata-se da beleza, elemento relevante na recepção do Conhece-te a ti mesmo. Dado o forte apelo sensível da poética será primeiro necessário investigar as origens e as modificações do conceito do belo, atualizando-o no final para a recepção contemporânea dos objetos-oráculo ${ }^{23}$.

Na segunda parte do capítulo analisa-se especificamente a metáfora do oráculo, investigando-se a relação dialética que pode estabelecer-se entre obra e espectador ${ }^{24}$.

Por meio da teoria da formatividade de Pareyson ${ }^{25}$ encontram-se três pontos de apoio para a estética do Conhece-te a ti mesmo:

- $\quad$ O conceito de beleza recolocado;

- $\quad$ A definição de arte que abrange o processo criativo tradicional da

poética;

- $\quad$ A idéia de colóquio ${ }^{26}$ entre obra e espectador que confirma a dialética da recepção do oráculo.

\footnotetext{
${ }^{22} \mathrm{O}$ título escolhido provém de uma idéia expressa na teoria do efeito estético de Iser, o principal ponto de sustentação do capítulo, na qual o receptor, ao final do processo de leitura de uma obra de arte, também formula algo novo sobre si próprio.

${ }^{23}$ Os principais autores adotados para o estudo são Gadamer e Bodei. Este último apresenta a história das idéias sobre beleza enquanto Gadamer examina os valores do belo que não mudam na arte, adaptando-se o estudo às três teorias principais do capítulo na segunda parte. Cf. Hans Georg GADAMER, $A$ Atualidade do Belo. Remo BODEI, As Formas da Beleza. Os autores de apoio, esclarecedores de questões pontuais são: DORFLES, DUFRENNE, PANOFSKY, VALÉRY.

${ }^{24}$ São utilizadas três teorias de orientação: a da formatividade (Pareyson), a da obra aberta (Eco) e a do efeito estético (Iser). Cf. Luigi PAREYSON, Os Problemas da Estética; Umberto ECO, A Obra Aberta; Wolfgang ISER, $O$ Ato da Leitura. Também nesta parte recorre-se à ajuda de outros autores. São eles: LANGER, LEENHARDT, PLAZA, SARTRE, TAVARES.

${ }^{25}$ A teoria data de 1954. Os Problemas da Estética, que reúne seus pontos essenciais é de 1966.

${ }^{26}$ Grifo meu.
} 
A teoria da obra aberta de Eco ${ }^{27}$ também escora a recepção proposta pelo oráculo em três momentos.

- Ao tratar do estímulo estético, incentivo para a elaboração de respostas do espectador frente a uma leitura múltipla;

- $\quad$ A abertura programática determinada pela intenção criadora;

- $\quad$ A desvinculação postulada pelo autor entre a linguagem utilizada e a abertura de significados de uma obra. $O$ valor estético não se baseia na novidade da linguagem em si, mas no uso original que se pode fazer das convenções disponíveis.

A teoria do efeito estético de Iser ${ }^{28}$ encerra o capítulo erguendo seus principais alicerces. Propõe a constituição de um sentido que se formula a partir das condições dadas pela própria obra na interação dialética entre esta e seu espectador ${ }^{29}$. O resultado do processo, a formulação da obra realizada pelo espectador, propicia-lhe ao final sua própria formulação como ser.

A presença das idéias de Iser procura sintetizar a analogia concebida entre o formular-se a si próprio com a tradução, no contexto da recepção do Conhece-te a ti mesmo, da sentença apolíneo-socrática. Tentando, contudo, não contrariar o pensamento de Nietzsche, quando este se contrapõe à sentença-título socrática da dissertação preferindo o processo pelo qual "tornamo-nos o que somos" ${ }^{30}$, o que implica, mais do que se voltar para si, ir além de si mesmo ${ }^{31}$. Coincidentemente, para o filósofo a superação do socratismo estaria na "valorização do poético" ${ }^{32}$.

\footnotetext{
${ }^{27}$ A Obra Aberta é de 1969.

${ }^{28}$ Wolfgang Iser. O Ato da Leitura data de 1987. As teorias iniciais do autor datam dos anos 70.

${ }^{29}$ Chamado de leitor por Iser, já que a teoria nasce voltada para a literatura. É possível, porém, a ponte com as artes plásticas graças à semelhança dos processos de leitura e seus resultados e pelos autores usados por Iser, que tratam da psicologia de leitura de imagens, como Arnheim e Sartre.

30 "Torna-te aquilo que és" ou "Génoi hoios essi". Frase de Píndaro usada por Nietzsche e bordada num dos oráculos (Tautologia).

${ }^{31}$ Jorge LARROSA. Nietzsche e a Educação.p.74.

${ }^{32} \mathrm{O}$ que Vattimo define como a "centralidade do estético" na obra do filósofo. Cf. Gianni VATTIMO, $O$ Fim da Modernidade.p.92-93.
} 
Intenta-se aqui, portanto, apresentar a possibilidade, mediante a metáfora do oráculo, de que a idéia de ir além de si próprio possa se concretizar por meio da recepção, por meio da indagação acerca dos significados de uma obra e do próprio movimento que leva o espectador a aproximar-se dela, descobrindo-se assim algo novo não só sobre o trabalho artístico, mas sobre si próprio.

No terceiro capítulo, O Nascimento da Tragédia, a abordagem dos autores escolhidos gira em torno da tentativa de compreensão da obra homônima de Nietzsche partindo das semelhanças encontradas entre esta última e o tema da dissertação.

Toma-se emprestado o título do livro pelas coincidências encontradas entre alguns pontos de $O$ Nascimento da Tragédia com a poética que se delineava no momento da leitura. As associações imediatas surgiram com a menção do oráculo de Delfos pelo filósofo e sua conexão com Apolo, deus das artes visuais, da necessidade estética da beleza para o homem e da exigência do Conhece-te a ti mesmo ${ }^{33}$. Concomitantemente deu-se a descoberta do aspecto dionisíaco, da densidade das questões decorrentes da polaridade e da complementaridade entre Apolo e Dioniso que se manifestam na arte, que não permitiram uma leitura apenas intuitiva.

O objetivo principal do quadro teórico selecionado é, a partir de uma leitura coerente da obra de Nietzsche, intentar um avizinhamento entre $O$ Nascimento $d a$ Tragédia e o Conhece-te a ti mesmo para contextualizar o segundo em relação ao primeiro apontando as congruências, assumindo as incongruências para formar uma intersecção possível entre ambos.

Seguindo os temas de $O$ Nascimento da Tragédia e do pensamento do primeiro Nietzsche, são abordadas no capítulo o conceito de arte e o papel que desempenha para o indivíduo, o caráter da beleza apolínea nas artes plásticas e a conciliação das polaridades simbolizada pela complementaridade Apolo-Dioniso.

\footnotetext{
${ }^{33}$ Friedrich NIETZSCHE. O Nascimento da Tragédia. p.40.
} 
As proposições do Conhece-te a ti mesmo que são aproximadas da obra de Nietzsche são o oráculo como metáfora da recepção, o sentido da beleza aparente e seu papel na metáfora eleita e a conciliação das polaridades contidas na relação entre a sentença-título da dissertação e a obra do filósofo ${ }^{34}$.

\footnotetext{
${ }^{34}$ Para alcançar os objetivos propostos optou-se por eleger dois autores norteadores das principais direções de leitura e outros de apoio, cujos textos iluminaram pontos isolados das questões encontradas pelo caminho. Safranski reúne à visão geral das principais questões da obra do filósofo uma contextualização biográfica, social e histórica. Benchimol concentra-se sobre $O$ Nascimento da Tragédia, apresentando a concepção de arte nitzscheana por meio das figuras de Apolo e Dioniso. Cf. Márcio BENCHIMOL. Apolo e Dionisio; Rudiger SAFRANSKI. Nietzsche. Em livros e artigos foram os autores: BEARDSWORTH, BLONDEL, COLLI, FORNAZARI, FURTADO, JIMENEZ, LACOSTE, LARROSA, MACHADO, VATTIMO.
} 
Imagens dos trabalhos

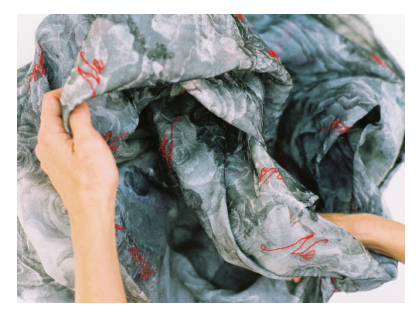




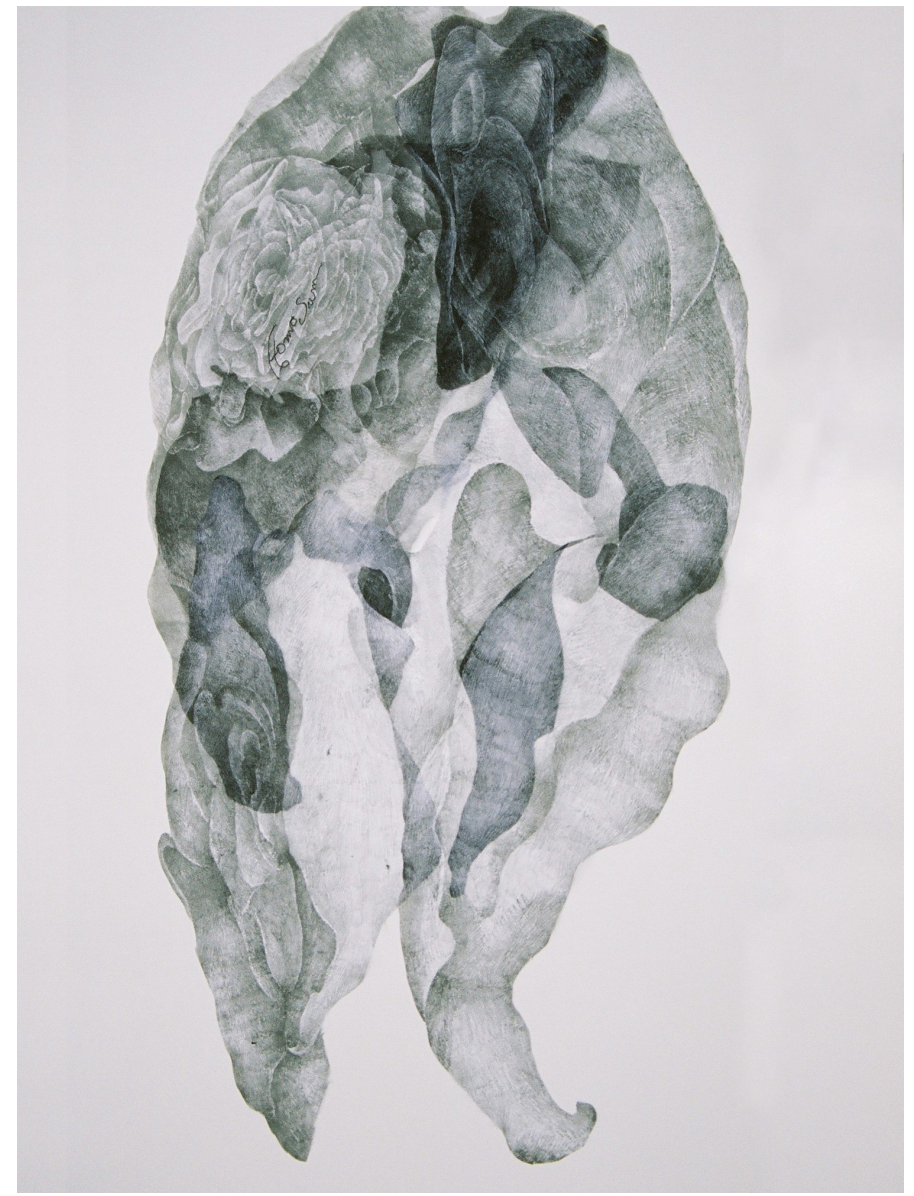

Fenda Oracular (Homo sum)

Bordado sobre monotipia feita sobre organdi recortado e costurado, 2005. $155 \times 82 \mathrm{~cm}$. 


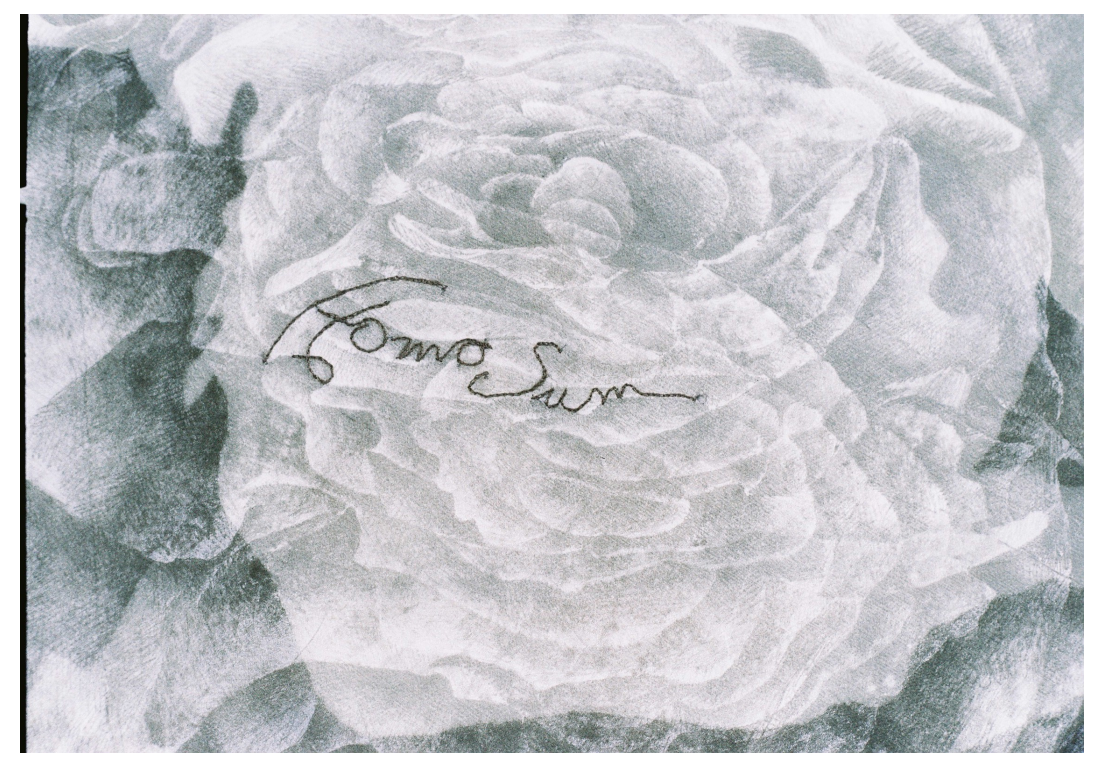

(detalhe) 


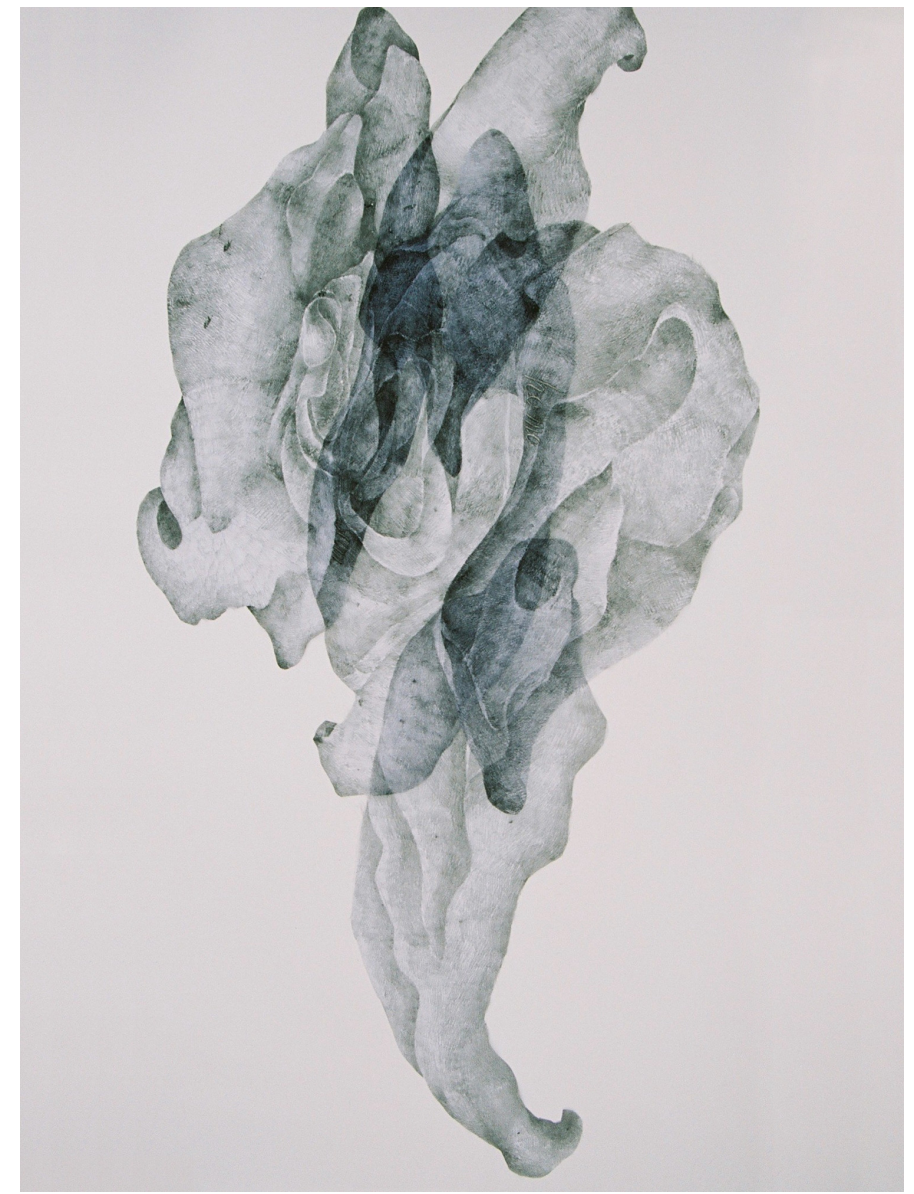

Fenda Oracular (Homo sum)

Bordado sobre monotipia feita sobre organdi recortado e costurado, 2005. $114 \times 123 \mathrm{~cm}$ 


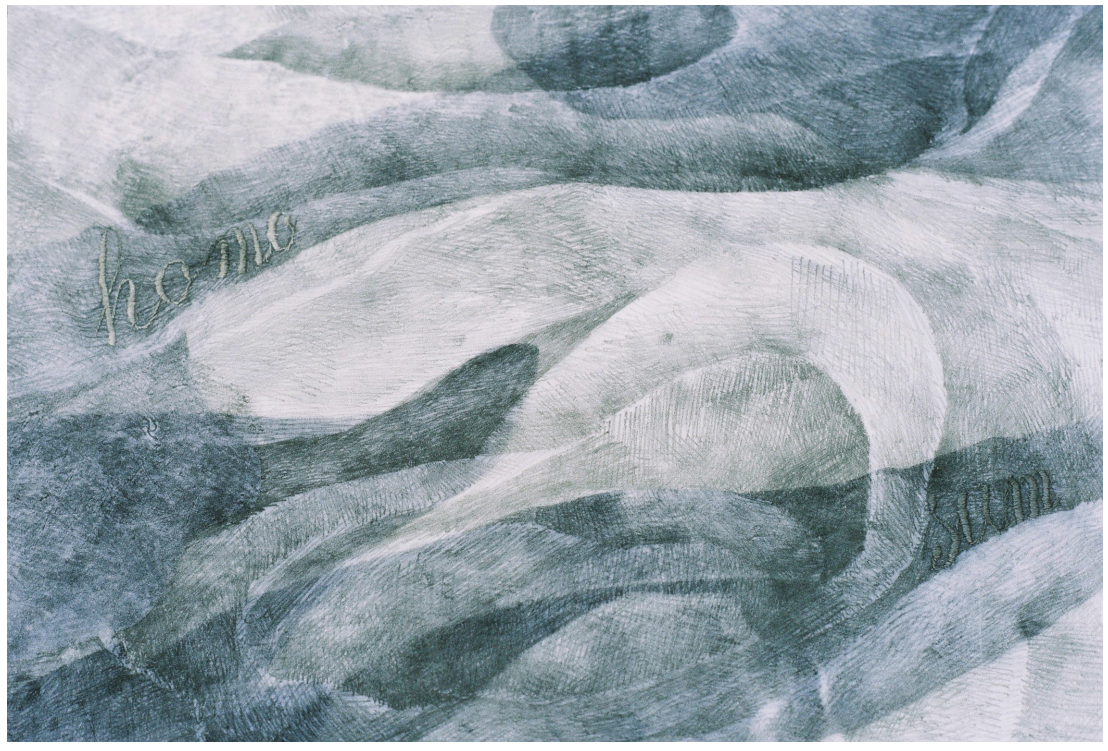

(detalhe) 


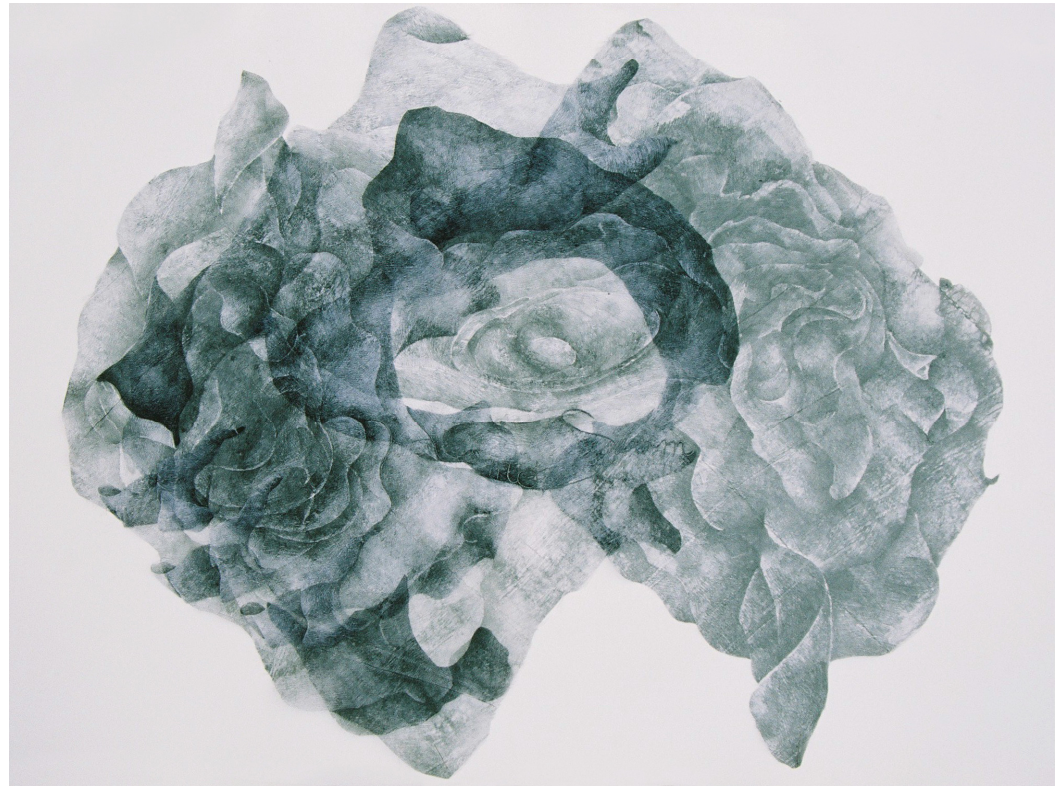

Fenda Oracular (Homo sum)

Bordado sobre monotipia feita sobre organdi recortado e costurado, 2005. $85 \times 87 \mathrm{~cm}$. 


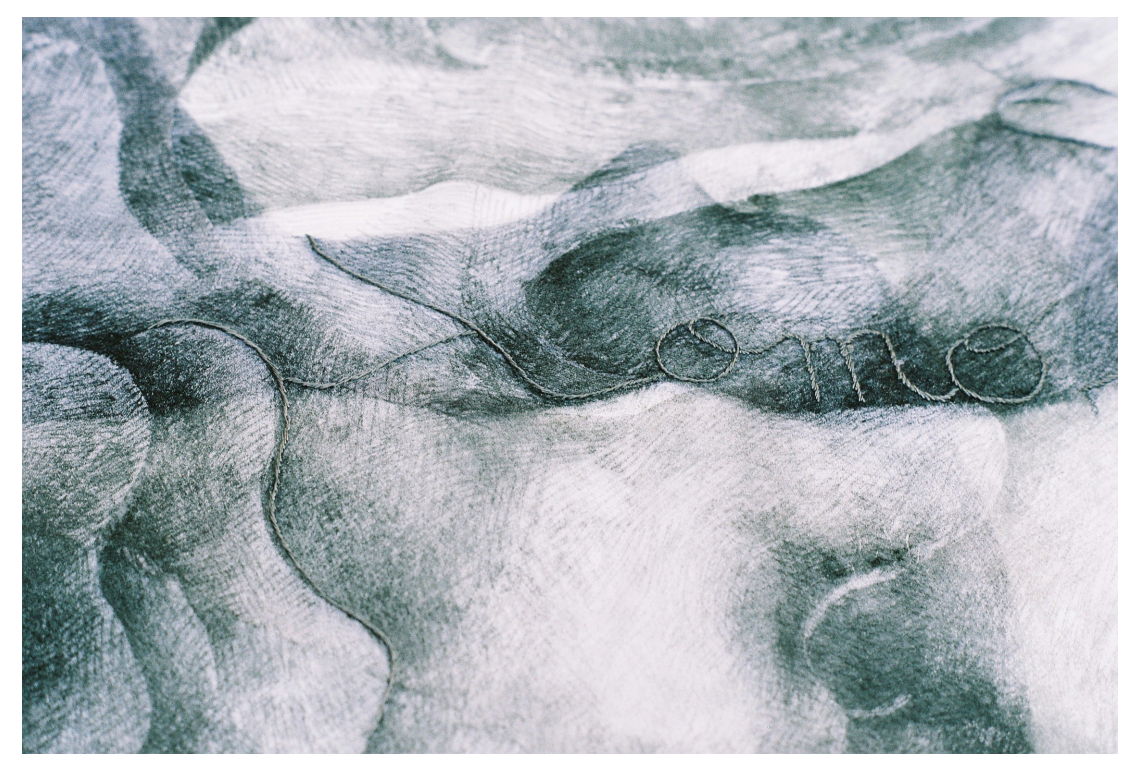

(detalhe) 


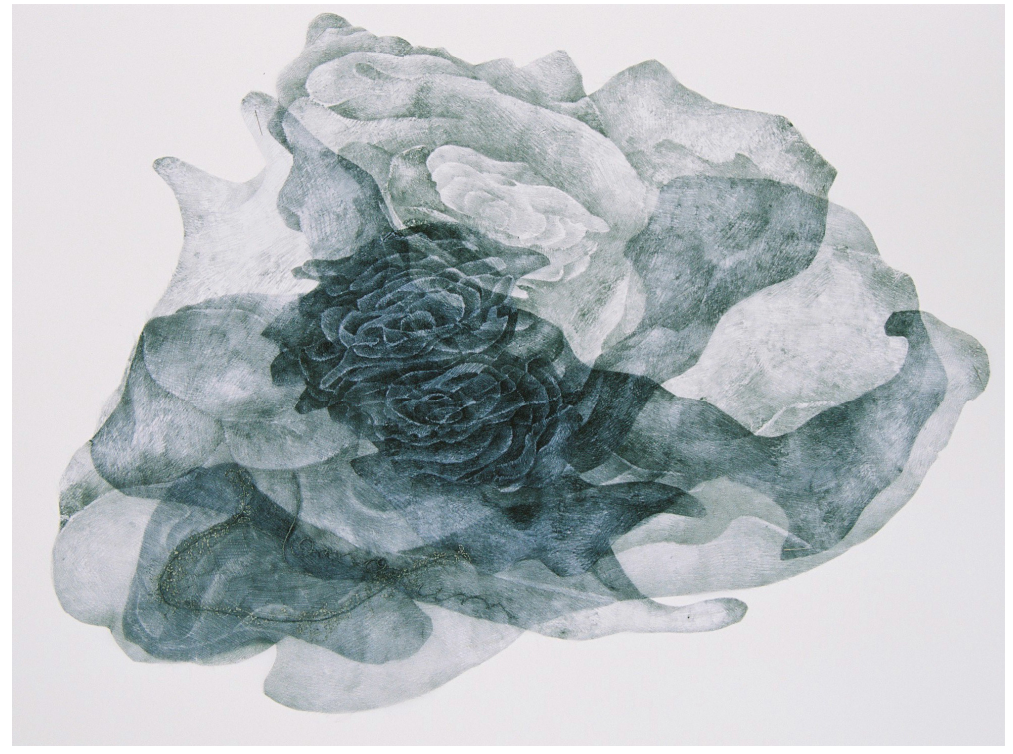

Fenda Oracular (Homo sum)

Bordado sobre monotipia feita sobre organdi recortado e costurado, 2005. $77 \times 98 \mathrm{~cm}$. 


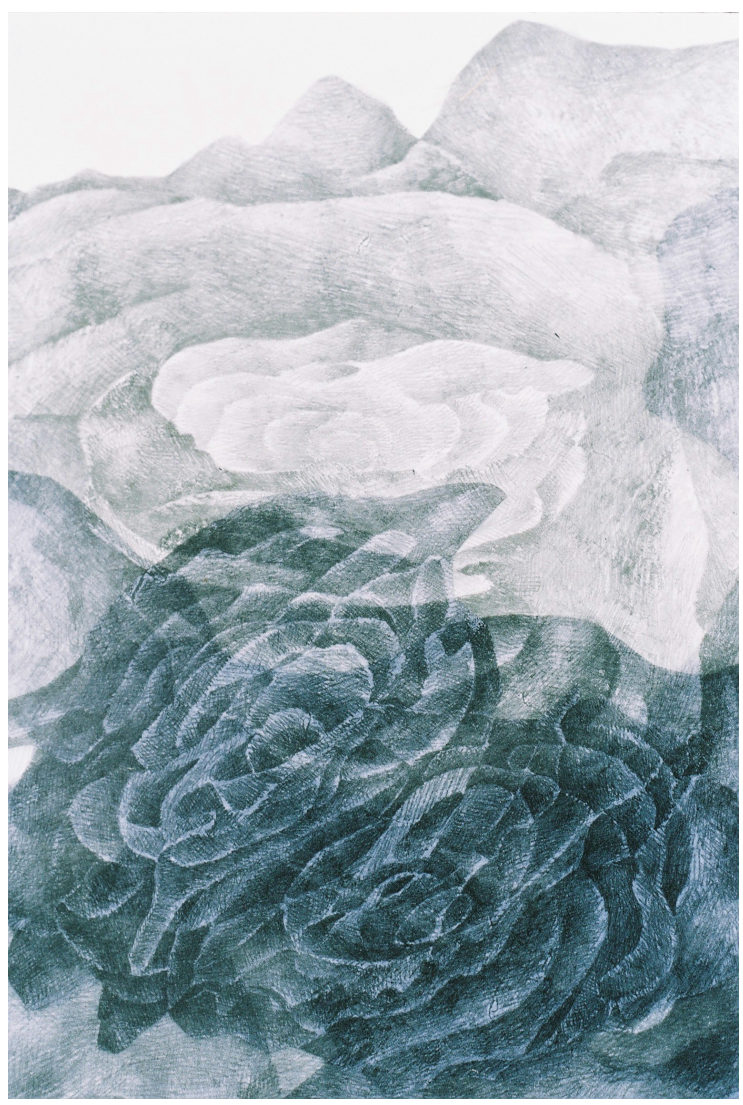

(detalhe) 


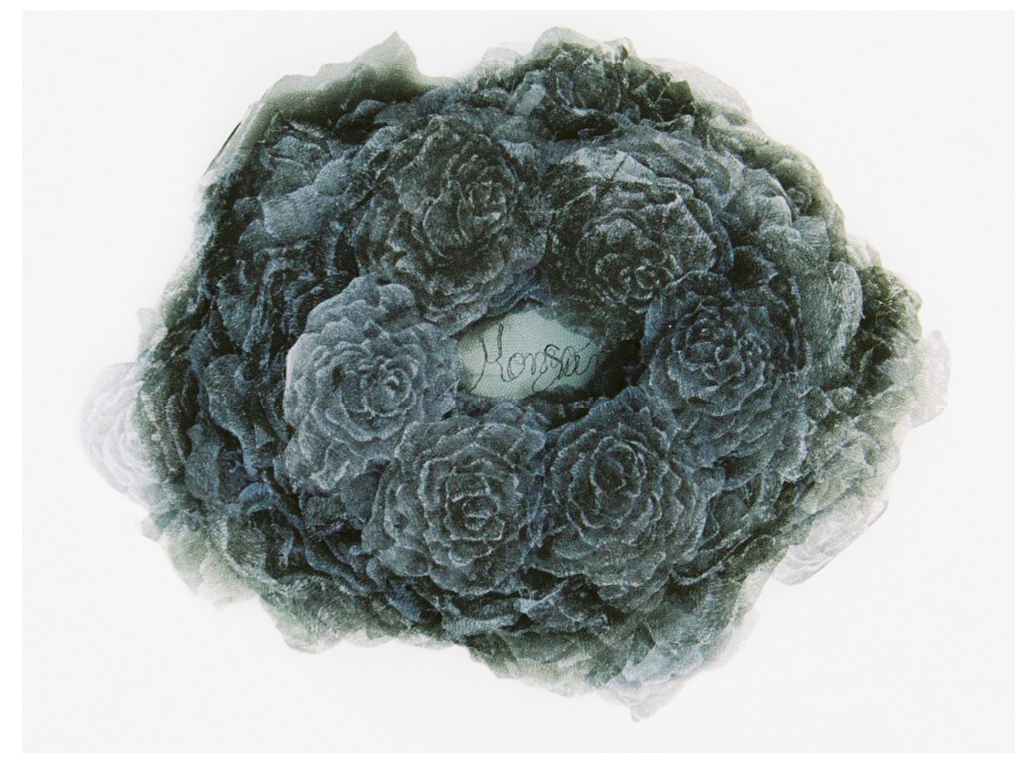

Oráculo Portátil (Homo sum)

Alinhavo sobre tule, monotipia sobre organdi recortado e costurado, 2005. $9 \times 30 \times 38 \mathrm{~cm}$. 


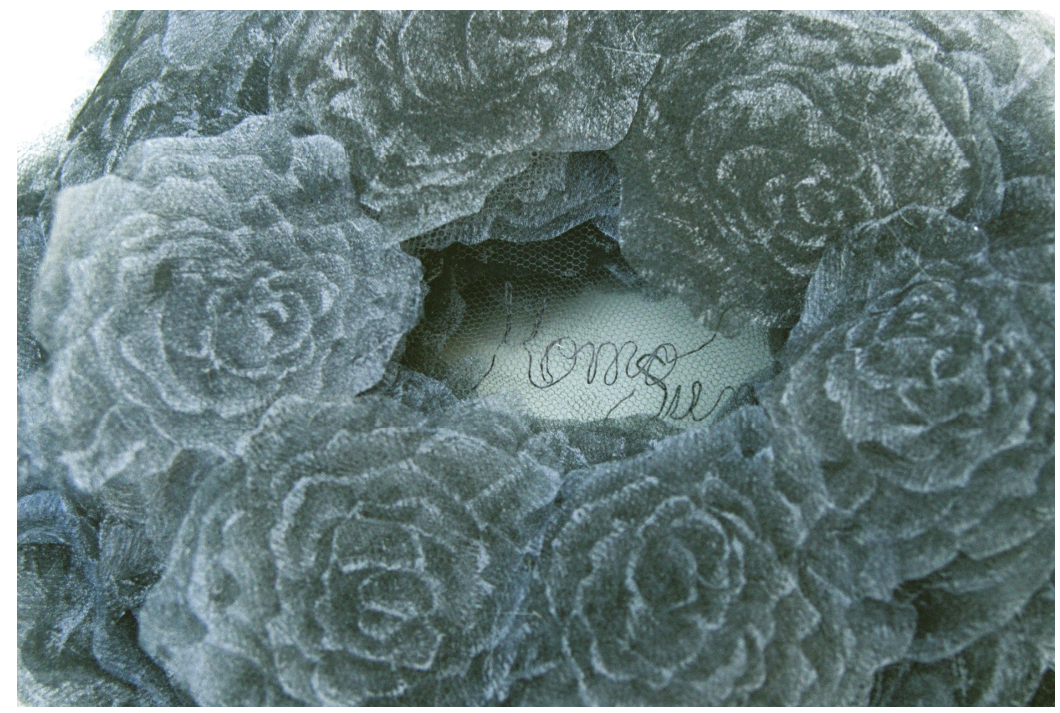

(detalhe) 


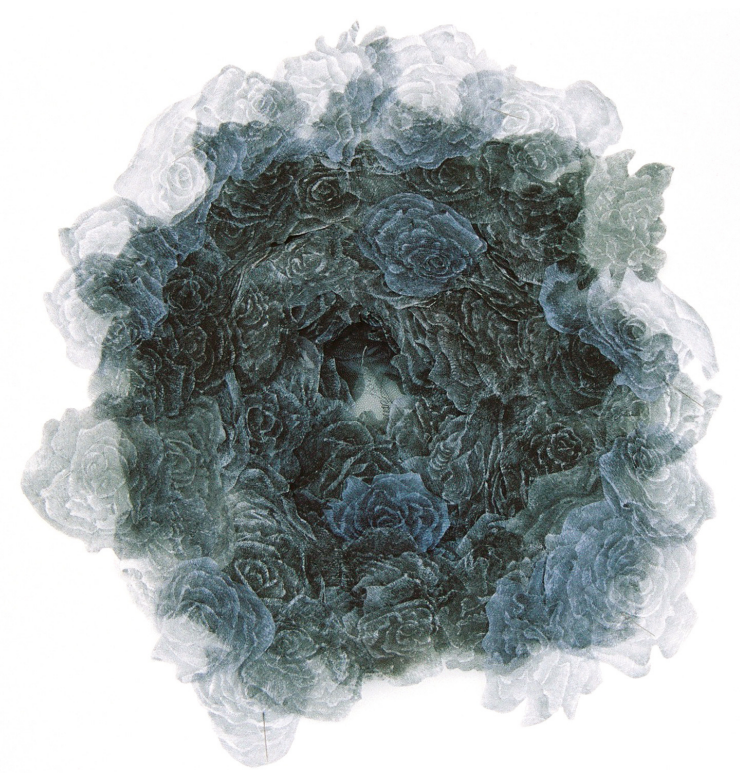

Oráculo Portátil (Homo sum)

Alinhavo sobre tule, monotipia sobre organdi recortado e costurado, 2005. $6 \times 43 \times 47 \mathrm{~cm}$. 


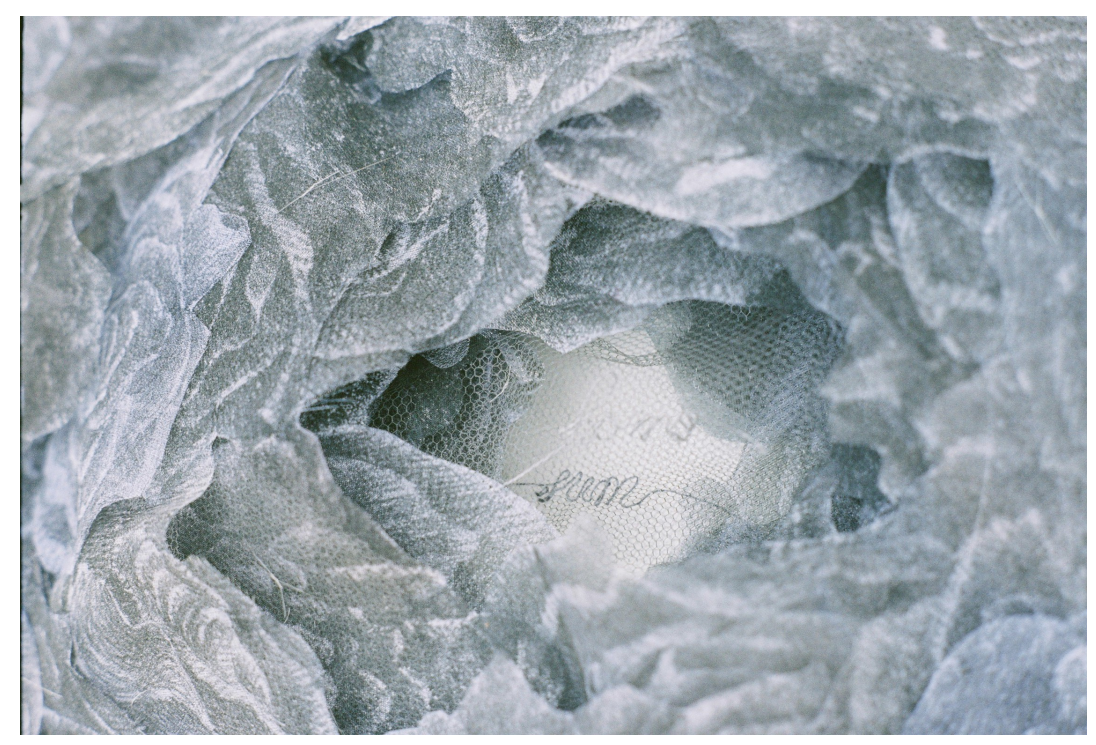

(detalhe) 


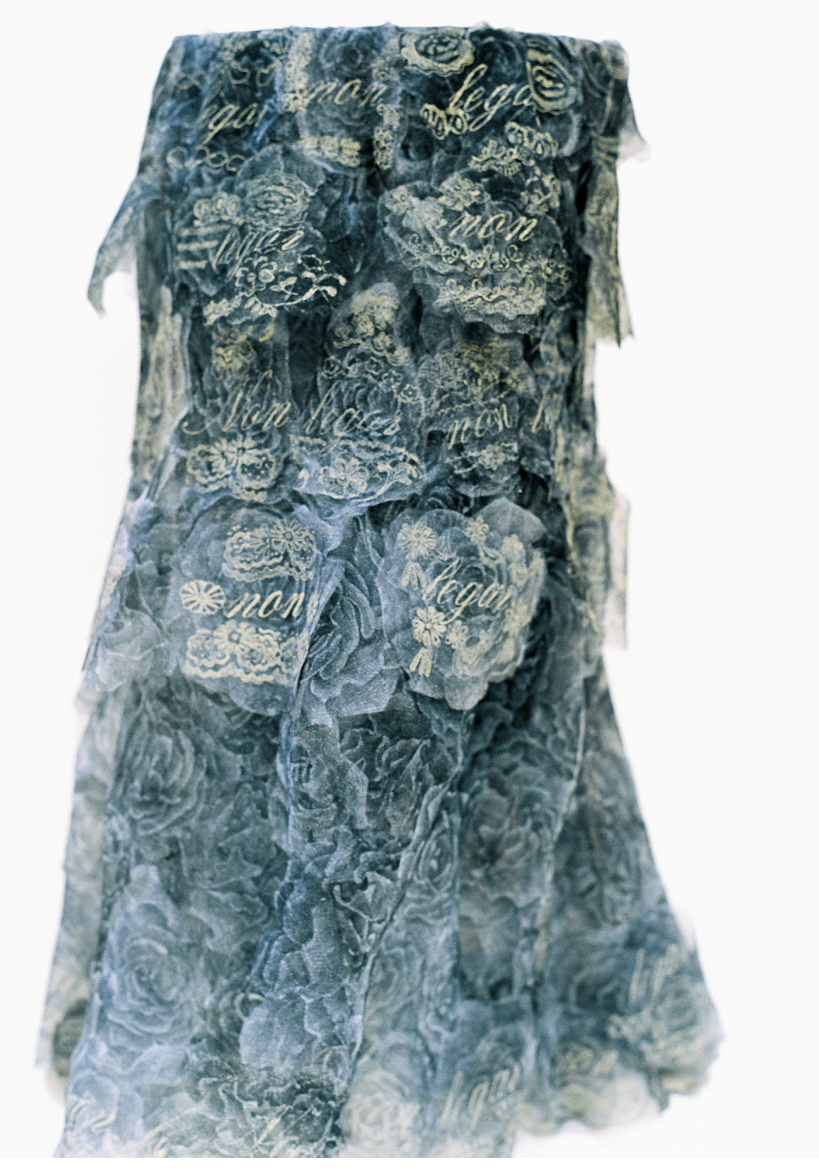

Oráculo Portátil (Non legor, non legar)

Desenho com papel carbono sobre monotipia feita sobre organdi recortado e costurado, 2005. $70 \times 45 \times 45 \mathrm{~cm}$. 


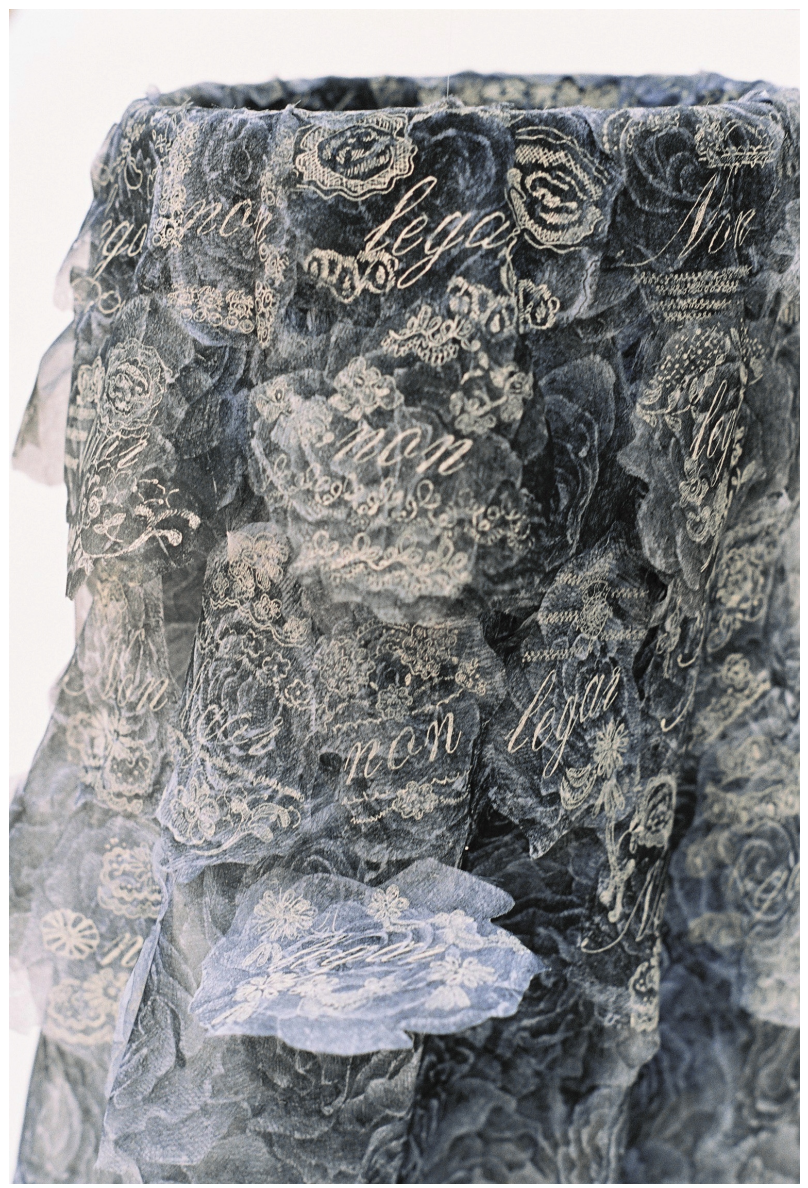

(detalhe) 


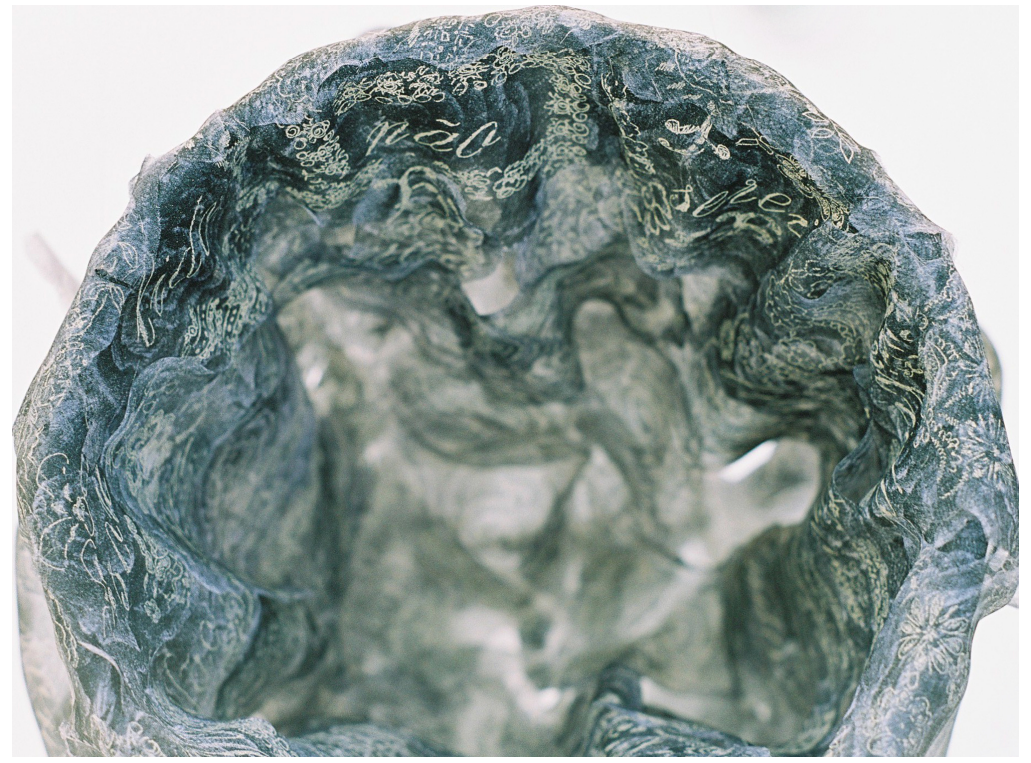

(detalhe) 


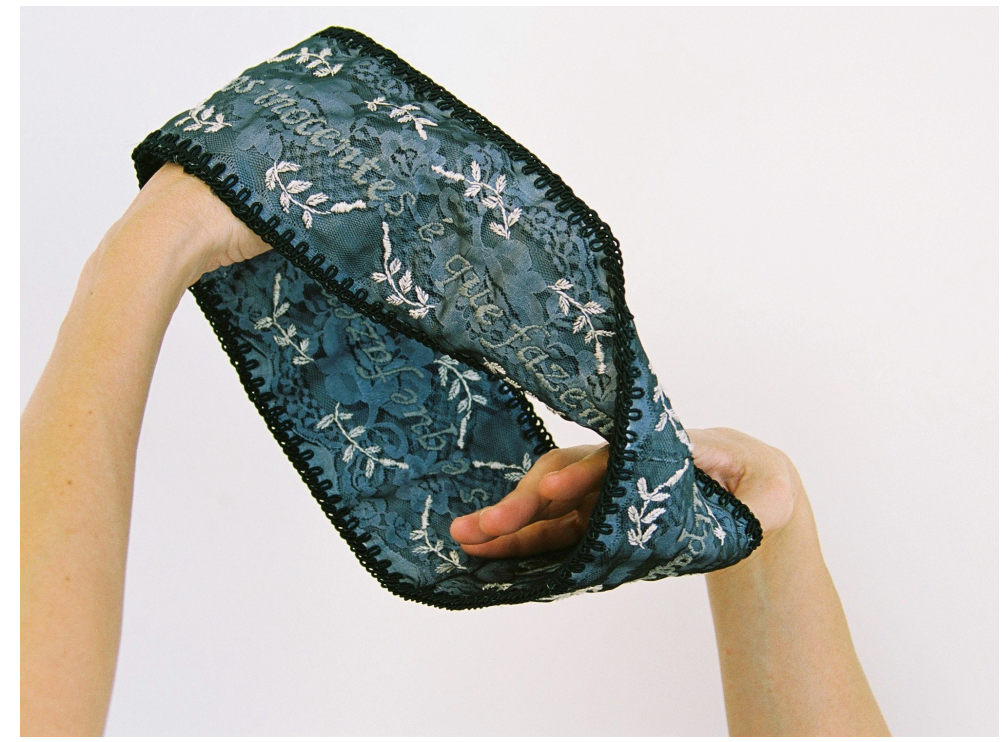

Tautologia (Os culpados é que fazem os inocentes; os inocentes é que fazem os culpados)

Bordado sobre renda e voile, 2004.

$11 \times 26 \times 26 \mathrm{~cm}$. 


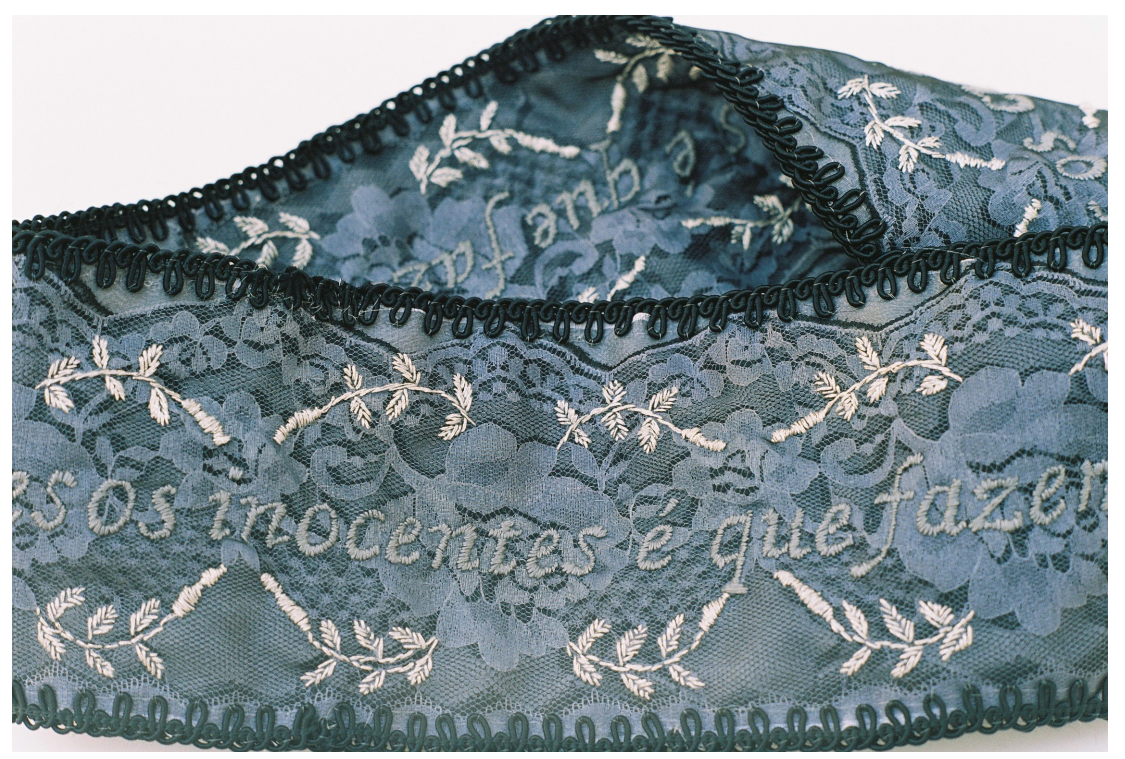

(detalhe) 


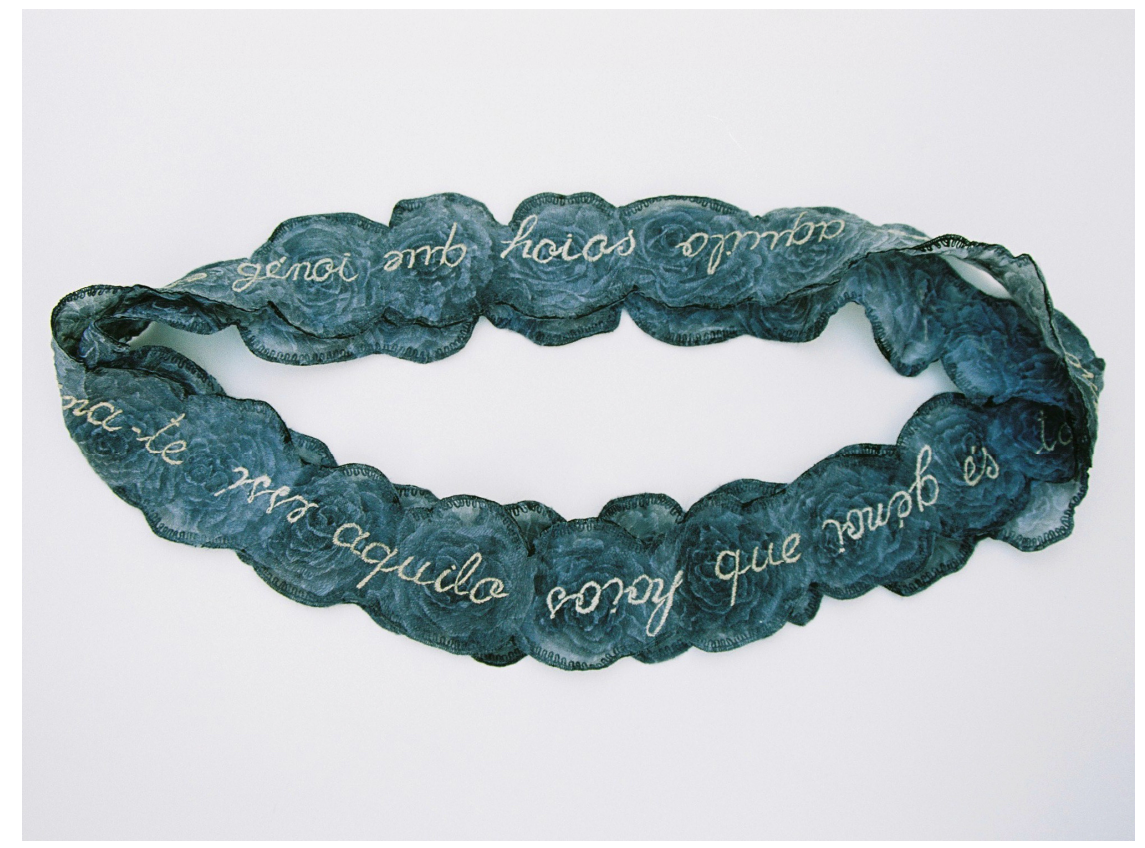

Tautologia (Génoi hoios essí;Torna-te aquilo que és)

Bordado sobre monotipia feita sobre organdi recortado e costurado, 2006. $11 \times 77 \times 77 \mathrm{~cm}$. 


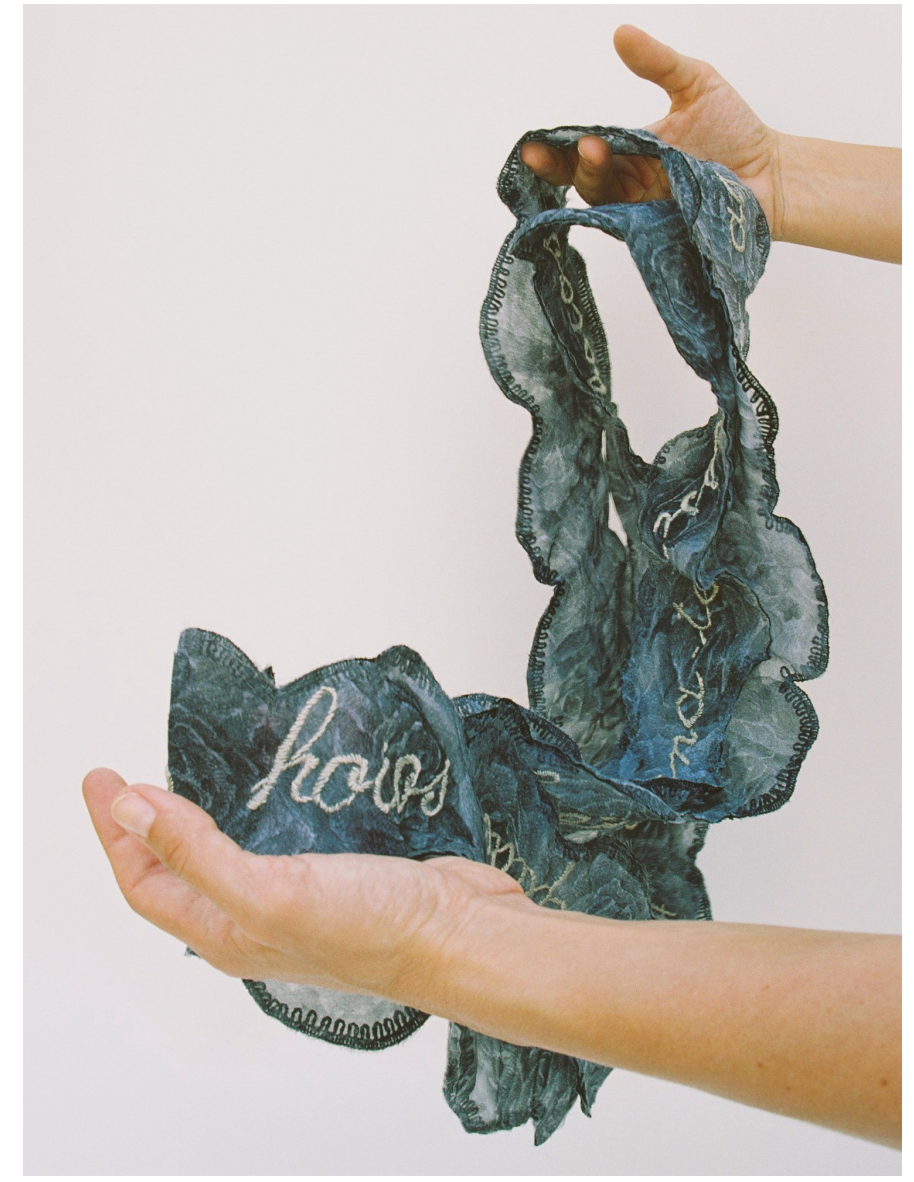

(detalhe) 


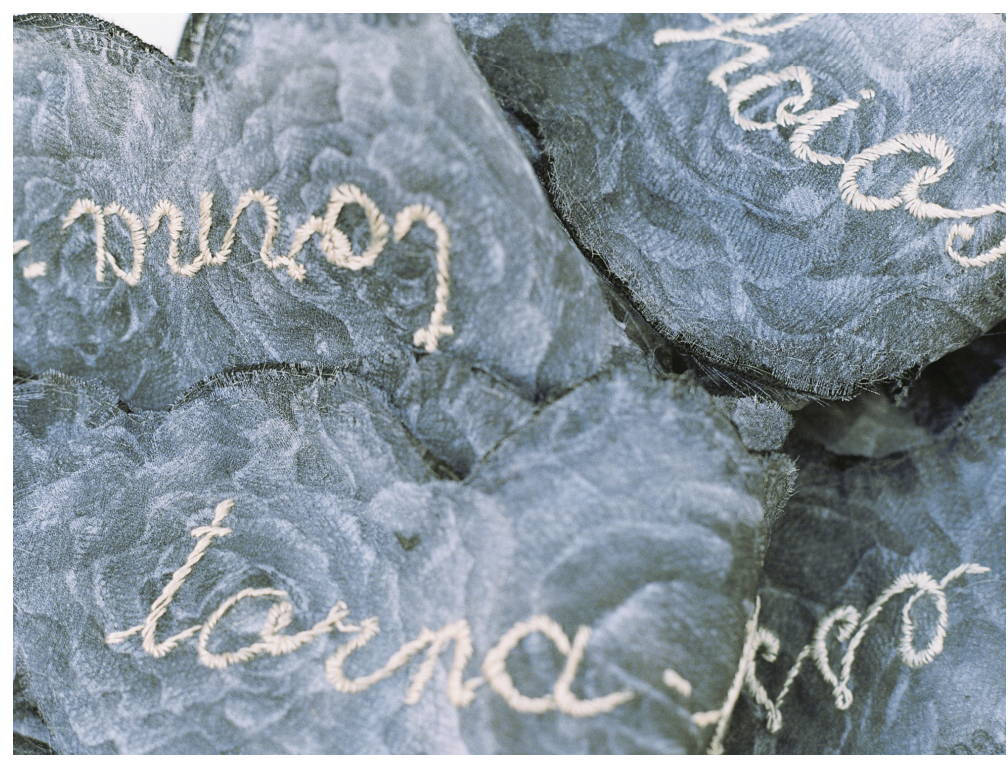

(detalhe) 


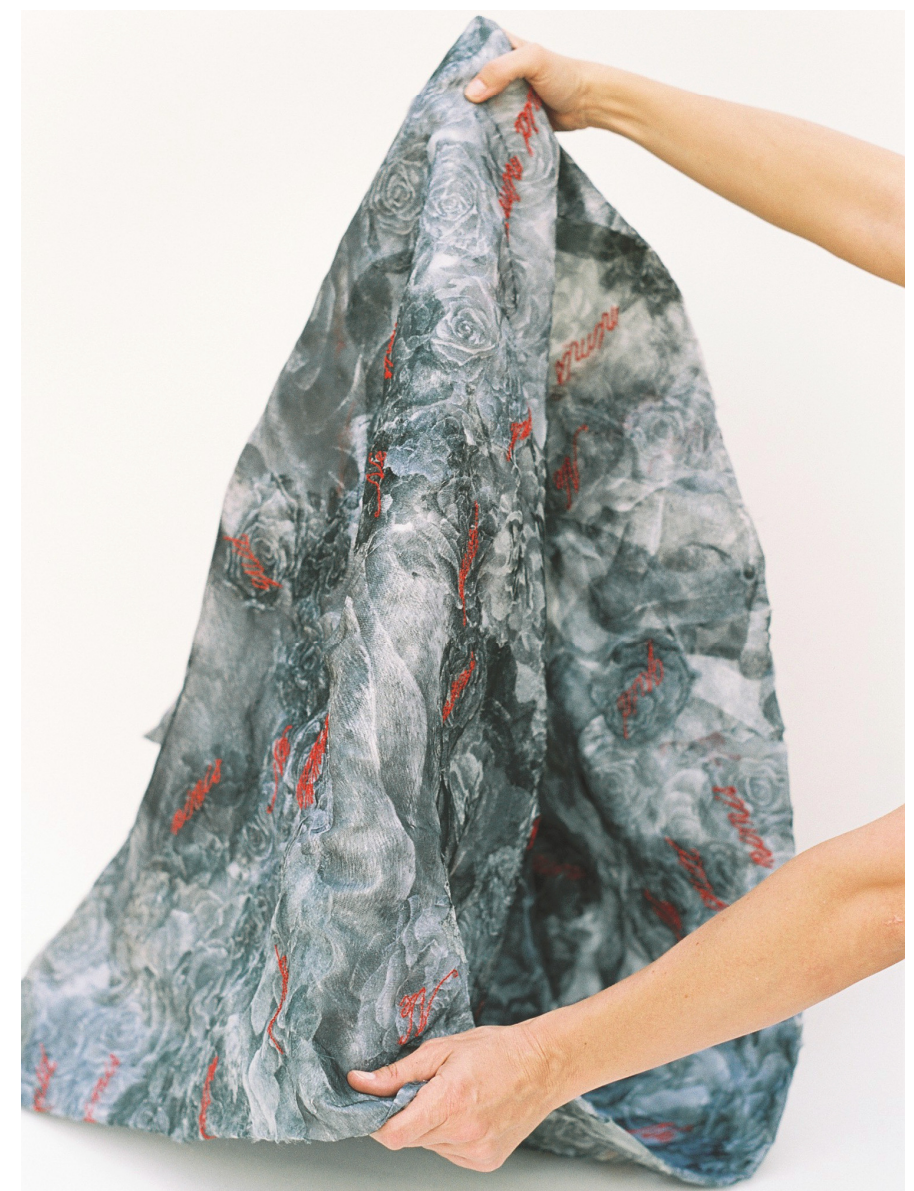

\section{Tautologia (Ne quid nimis)}

Bordado sobre monotipia feita sobre organdi recortado e costurado, 2006. $92 \times 67 \times 67 \mathrm{~cm}$. 


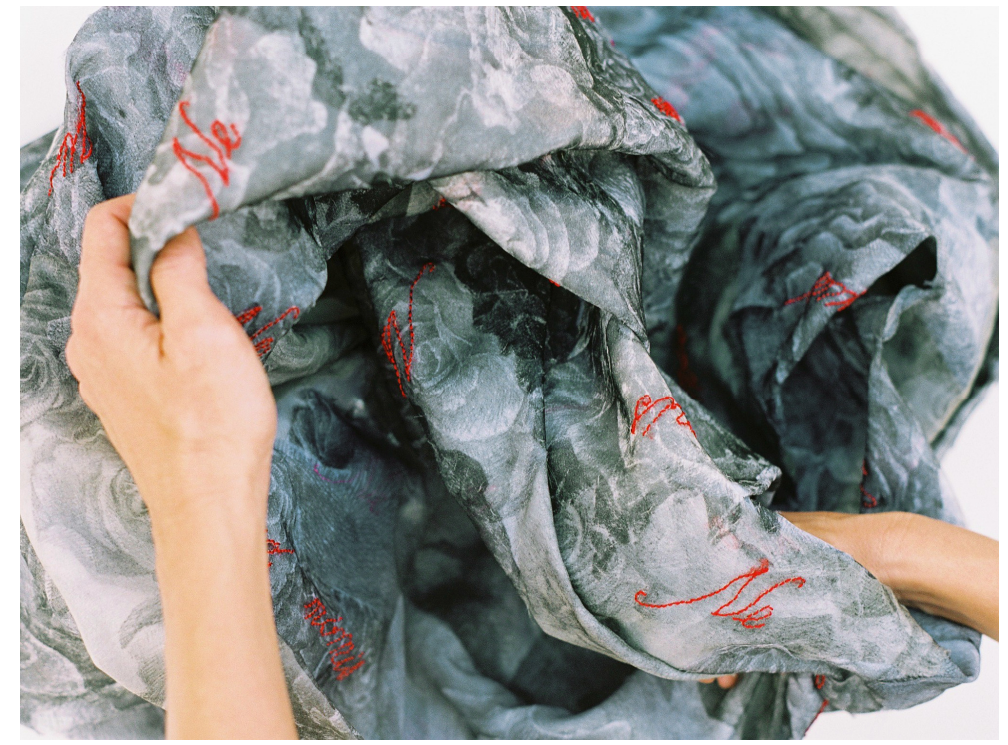

(detalhe) 


\section{Primeiro capítulo}

Conhece-te a ti mesmo

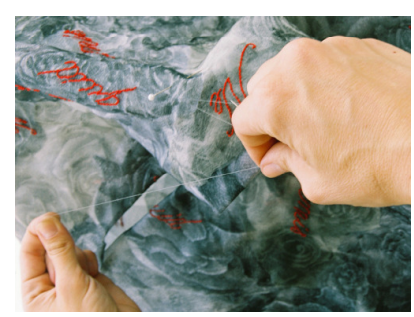




\section{Conhece-te a ti mesmo}

Eupalinos: "De tanto construir", disse-me sorrindo, "creio ter-me construído a mim mesmo". Sócrates: "Construir-se, conhecer-se a si mesmo, são dois atos ou não?" ${ }^{35}$.

Paul Valéry

Há um estreito vínculo entre os dois atos citados na formação de um trabalho artístico. Um e outro alternam-se, alimentam-se mutuamente, necessitam-se. Um ato matérico, ativo -- permite o passo seguinte do outro - retrospectivo, contemplativo -- à medida que a construção se desenvolve.

Para explicitar a direção a ser seguida são apresentados aqui os sentidos pensados para cada um dos dois atos. A construção engloba a idealização, a elaboração e a realização de um objeto. Conhecer-se a si mesmo significa aqui percorrer novamente o caminho da construção de forma reflexiva e analítica sob o ponto de vista de quem cria e de seus interesses característicos.

O capítulo de nome homônimo à dissertação olha para as obras. Investiga-se tanto o processo de "vir a ser" das idéias e trabalhos que originaram a série do Conhecete a ti mesmo quanto como este se manifesta particularmente em cada obra ${ }^{36}$. Está sob atenção o pensamento criador que, por meio da ação física, gera o produto acabado ${ }^{37}$.

Neste capítulo objetiva-se "explicitar procedimentos" ${ }^{38}$ na tentativa de dar forma a uma reflexão sobre as etapas do processo criativo, sobre os métodos de criação

\footnotetext{
${ }^{35}$ Paul VALÉRY. Eupalinos ou O Arquiteto.p.51.

${ }^{36}$ Julio PLAZA e Mônica TAVARES. Processos Criativos com os Meios Eletrônicos: Poéticas Digitais.p.65.

${ }^{37}$ MILLET apud J.PLAZA e M.TAVARES.Ibidem.p.65.

${ }^{38}$ Regina SILVEIRA. Produção Artística e pesquisa: Situação Atual. Anais ANPAP. p.25.
} 
e para buscar as raízes e afinidades desta poética no âmbito de sua própria genealogia e desenvolvimento.

Ao refletir sobre o próprio trabalho no contexto acadêmico, o artista tem o desafio de construir um discurso auto-reflexivo coerente, não apenas descritivo, que seja capaz de contribuir para a ampliação de sua própria consciência artística e capaz de despertar o interesse de possíveis leitores.

O artista deve pôr à prova suas hipóteses sobre as significações de seu trabalho defrontando-as com um referencial teórico. Contudo, sem relegar a poética para um segundo plano, permitindo que esta se expresse em seu modo único e intraduzível.

Na seguinte citação de Regina Silveira encontro a exata descrição do que constitui para o artista o texto reflexivo:

"(...) registra a atitude analítica e reflexiva do artista, orientada para a sua criação e para o campo de idéias onde ela se inscreve, na apresentação organizada e sistemática de sua investigação" ${ }^{39}$.

Note-se que em vários momentos da dissertação delineiam-se polaridades complementares.

Pense-se na contraposição fundadora entre o apolíneo e o dionisíaco. Um de seus aspectos é o que toca nos limites do alcance do conhecimento por meio do logos. Transferindo-a para a situação do Conhece-te a ti mesmo, do discurso sobre o processo criativo que se dá concomitantemente ao próprio processo criativo, surgem questões.

Ao se seguir o valor dado ao pensamento socrático e a posição privilegiada que confere à palavra e ao discurso, seu poder apolíneo de clarificação, que papel desempenha a reflexão simultânea e posterior desenvolvida pelo artista sobre sua própria criação?

\footnotetext{
${ }^{39}$ Regina SILVEIRA.Ibidem.p.25.
} 
Até que ponto o logos pode de fato corrigir e guiar a práxis especificamente no caso da criação artística? Seria este o papel desejável da reflexão teórica?

Reconhece-se em todo o pensamento moderno e especialmente no âmbito acadêmico a herança socrática da confiança na razão como instrumento de conhecimento e de modificação. No presente caso a razão debruça-se sobre o processo criativo, seu produto - a obra de arte - e tenta, na medida daquilo que é acessível na arte à consciência, trazer à luz suas origens, seus meios e suas ramificações.

A forma como se dá é a auto-reflexão que se reporta a um quadro teórico. Esse tipo de reflexão pode ter como um dos seus efeitos a modificação do Eu criativo. A reflexão voltada para a própria produção pode tornar-se constitutiva do desdobramento de uma poética apenas em parte, e esta não será nem fundamental, nem essencial para o seu desenvolvimento.

Se, por um lado, é fato que a seqüência alternada da construção da poética e da reflexão teórica influenciam-se e modificam-se mutuamente, por outro, a lição de Nietzsche sobre o necessário equilíbrio entre luz e escuridão confirma-se no pensamento de Silveira.

A artista pondera que o texto muito articulado arrisca-se a conceder maior peso ao discurso e não à pesquisa artística através de uma "ilusão da claridade":

"(...) por esquecer que as criações nascem em regiões nebulosas ou crepusculares da consciência" ${ }^{40}$.

É, portanto, valioso o aviso da artista pesquisadora: "É preciso olhar para as obras" ${ }^{41}$.

\footnotetext{
${ }^{40}$ A. MOLES apud Regina SILVEIRA. Ibidem p.26.

${ }^{41}$ Regina SILVEIRA. Ibidem.p. 27.
} 


\section{"O que fez o poeta e como ele o fez?",42}

De acordo com Rey a proposta e o modo de trabalhar do artista contemporâneo são de difícil leitura. Por conseguinte, para aproximar-se da compreensão de uma poética é preciso obter informações sobre os procedimentos técnicos usados pelo artista 43.

A produção artística desenvolvida desde 1999 até o início do mestrado apresenta peças que já foram descritas como pinturas-gravuras-objetos-esculturas ${ }^{44}$. São formadas por pequenas monotipias desenhadas individualmente à mão e impressas sobre organdi, sobrepostas e costuradas entre si. O resultado final assemelha-se, ao mesmo tempo, às quatro poéticas citadas, seja pelo processo de produção ou pela aparência final.

São peças que unem qualidades gráficas, pictóricas e escultóricas mesmo sem terem sido feitas direta ou exclusivamente por algum recurso típico dessas técnicas.

Nesse período inicial de quatro anos a poética progride e afirma-se. Origina-se evidentemente de séries de trabalhos anteriores, que remontam a 1992 e, sete anos depois, alcançam a aparência e os procedimentos utilizados até hoje. A partir de 2003 a poética atinge, por meio da confrontação e agregação da palavra, a idéia da série do Conhece-te a ti mesmo.

Desde o início desse processo a monotipia esteve sempre presente. Pode-se considerá-la o motivo condutor da expansão da poética, o meio técnico de sustentação e provocação das experimentações, propositor de desafios ao atingir os limites das formas e dos suportes usados. A importância da monotipia permite aqui uma pequena digressão sobre suas origens e sua estética.

\footnotetext{
${ }^{42}$ Susanne LANGER. Sentimento e Forma. p.9.

${ }^{43}$ Sandra REY. Notas Sobre Metodologia em Artes Plásticas. Anais ANPAP p.305.

${ }^{44}$ Mila Milene CHIOVATTO. Sobre Camadas. Texto crítico para folder de exposição. Galeria SESC Paulista, 2001.
} 
A monotipia é um método de impressão situado entre as artes gráficas e a pintura, cujos resultados, como o nome indica, são provas únicas e não idênticas ${ }^{45}$. Para a sua obtenção o usual é pintar-se uma imagem sobre uma superfície rígida e não absorvente sobre a qual pressiona-se por igual o suporte, geralmente papel ${ }^{46}$.

Uma maneira possível de se conseguir uma monotipia, já utilizada, por exemplo, por Mira Schendel ${ }^{47}$, é a de se entintar uniformemente uma superfície não absorvente, colocar-se sobre ela o papel e, desenhando-se no verso da folha, obter-se uma imagem apenas nas áreas onde se exerceu pressão ou sulcou-se o papel.

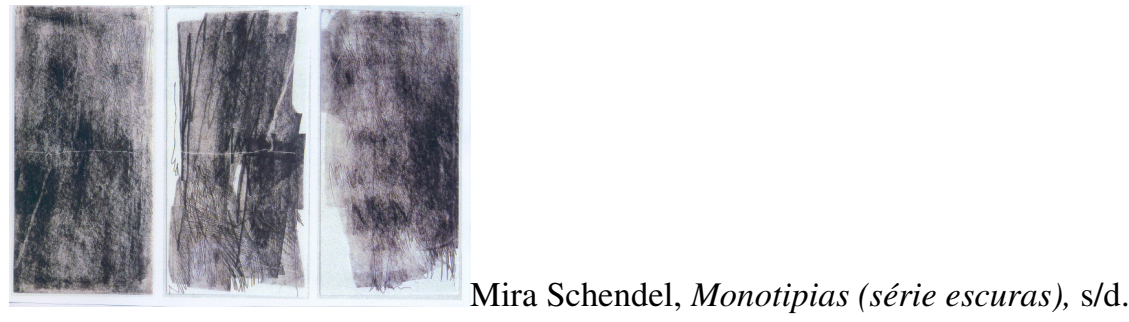

Ambas as formas geradoras de uma monotipia aqui descritas têm resultados não totalmente controláveis na frente do suporte, que incorporam o acaso e que privilegiam um gestual forte, incisivo.

Foi eleito aqui o modo de impressão usado por Mira Schendel por este favorecer o emprego do desenho, a possibilidade de se retrabalhar a imagem muitas vezes via

\footnotetext{
${ }^{45}$ Ralph MAYER. Manual do Artista.p.660.

${ }^{46} \mathrm{~A}$ origem da técnica da monotipia é incerta, pois seu uso nasce de diferentes formas, como estudo ou experimento. Um dos primeiros artistas a utilizar-se dela foi parece ter sido o paisagista holandês Seghers (Hercules Pietersz, pintor e gravador. Haarlem, 1590 - Amsterdam, 1639). Rembrandt (Harmenszoon van Rij. Leiden, 1606 - Amsterdam, 1639) possuía obras desse artista, foi por ele influenciado e, por sua vez, acredita-se que tenha influenciado Castiglione (Giovanni Benedetto, ou Grechetto. Genova, 1610 Mantova, 1665).Os dois últimos também experimentaram a monotipia para estudar efeitos na gravura que pudessem ser análogos a efeitos pictóricos. Existem vinte e duas monotipias conhecidas de Castiglione, cujas imagens criaram efeitos de aquarela. O artista desenhava na tinta espalhada sobre a placa de metal. Seu procedimento consistia em aplicar uma espessa camada de tinta preta ou marrom sobre a placa de metal. As linhas brancas eram marcadas retirando-se a tinta com um instrumento duro. As tonalidades intermediárias podiam ser obtidas com o uso dos dedos e de pincéis. O princípio dessa técnica origina, porém, diferentes métodos. Blake, Degas, Matisse e Schendel foram alguns dos artistas que se utilizaram da monotipia. Df. Heloísa NAVARRO.//brgeocities.com/heloisanavarro/Origem.htm.Acesso em: julho 2006.

${ }^{47}$ Como nas séries sobre papel arroz de meados dos anos 60 .
} 
sobreposição e, assim, avizinhar-se por uma outra forma de efeitos pictóricos, sempre sobre papel.

Uma das características mais citada e geralmente associada à monotipia contemporânea é a forte vinculação da técnica com o tempo: revelar-se-iam na impressão registros gráficos indicativos de um dado temporal.

Apesar de que na maior parte das vezes a monotipia seja considerada uma técnica de rápida obtenção de efeitos, de preservação de fenômenos casuais que ocorrem na imagem e de congelamento do gesto ${ }^{48}$, a experiência nesta poética, a partir de 1999, é compreendida de modo totalmente diferente. Quanto ao acaso, a principal referência para se estabelecer a qualidade do registro temporal da técnica, é às vezes incorporado nas monotipias-rosas, mas não é adotado como método criativo constante.

Nela não se percebe direta e principalmente uma alusão ao tempo nas imagens das rosas. O tempo está presente não na aparência final, mas no longo período de elaboração - aproximadamente vinte minutos para cada monotipia-rosa. A duração do desenho, que é idêntica e superposta à duração da impressão, esconde-se no resultado final.

A aparente repetição de imagens idênticas leva a pensar - exatamente ao contrário do que ocorre - de que o tempo de sua produção encurta-se graças a uma repetição da imagem que quase sempre é identificada erroneamente como mecânica, portanto mais rápida e com menor esforço empregado do que de fato acontece, pois uma estampa está associada à repetição da imagem de uma matriz ${ }^{49}$.

Na verdade a elaboração das monotipias-rosas é artesanal e irrepetível, com pouquíssimas variações, originária de uma estampa sem matriz, que conseqüentemente

\footnotetext{
${ }^{48}$ Luise WEISS. Monotipia: Algumas Considerações. Cadernos de Gravura.pp.19-20.

${ }^{49}$ Cláudio MUBARAC. Notas Sobre Incisão.p.07.
} 
deve ser recriada novamente a cada rosa. É possível, neste caso, reconhecer no procedimento a aplicação de um "sistema monótono" que nunca se repete ${ }^{50}$.

No suceder-se dos trabalhos, retornando-se agora à descrição da evolução da poética, nos anos de 1996 e 97, o papel foi se tornando um suporte muito "pesado" para as finas camadas de tintas a óleo e tipográfica. Iniciam-se nesse momento as pesquisas que levaram ao uso da monotipia tal como anteriormente descrito.

Revelaram-se outros limites também impostos pelo suporte: a opacidade que impedia um acompanhamento dos resultados concomitante ao desenvolvimento do trabalho, a sobreposição limitada a poucas camadas de tinta e as dificuldades quanto ao armazenamento e durabilidade do papel. Tais condições levaram às experimentações com tecido, material mais maleável.

A pesquisa com tecidos distinguiu-se paulatinamente chegando à combinação máxima possível entre pouca absorvência da tinta, transparência, leveza e resistência: o organdi.

Ao ser muitas vezes dobrado e sobreposto sobre si próprio, o tecido estampado por monotipia cresceu e tornou-se objeto tridimensional. É incorporado nesse momento o uso da costura como meio de construção das peças.

As monotipias-rosas são a "matéria-prima" dos objetos. Têm primeiro seus contornos desenhados a lápis sobre o organdi a partir de um desenho-matriz préexistente. Depois realiza-se a monotipia propriamente dita por meio de camadas de hachuras que gradativamente formam sombras e luzes sobre a superfície do organdi por absorverem a tinta tipográfica preta que recobre a placa de monotipia. Segue-se um período de secagem que dura aproximadamente quinze dias, seguido pelo recorte de cada flor e por fim a montagem do objeto imaginado.

\footnotetext{
${ }^{50}$ Ibidem.p.07.
} 

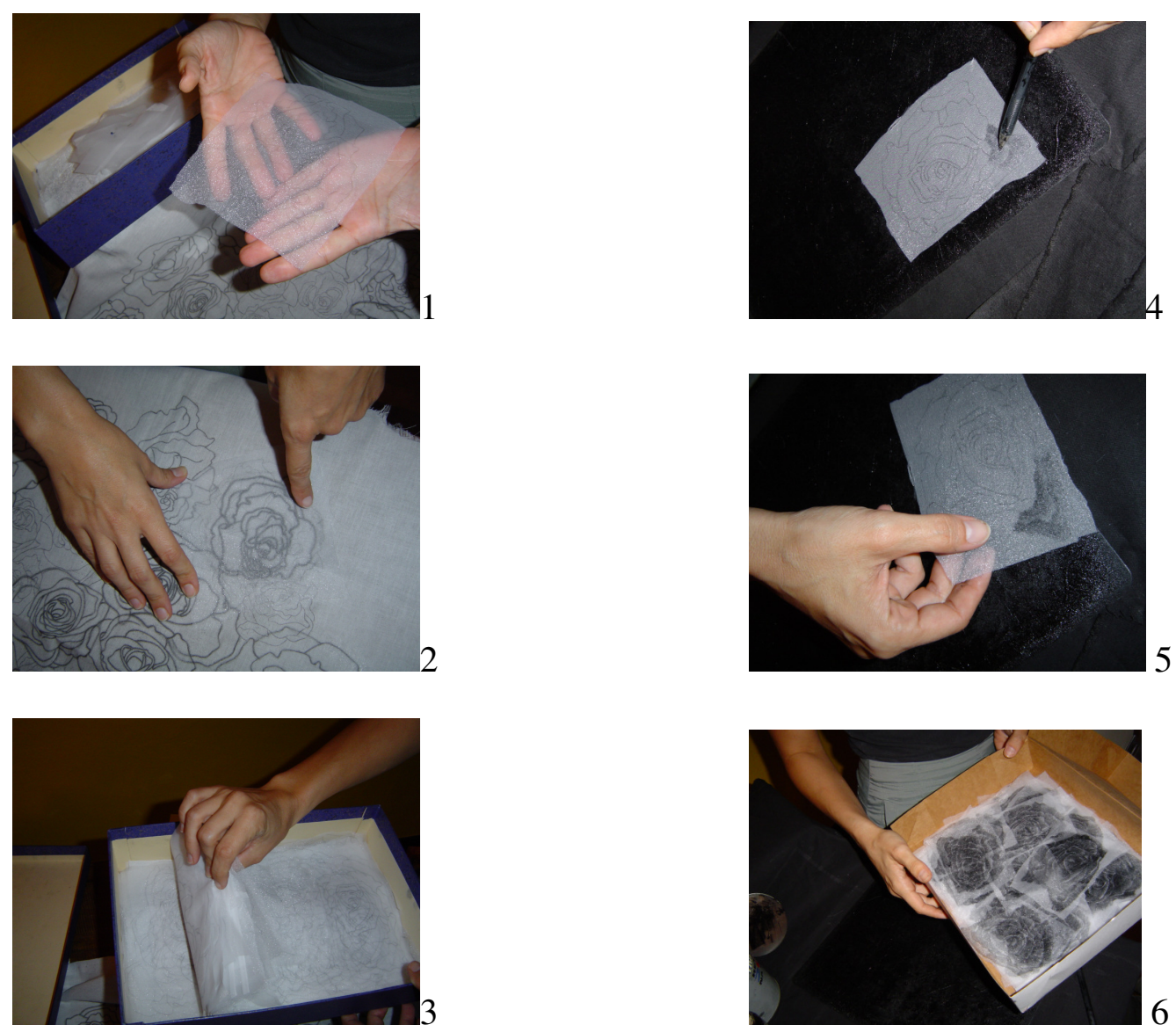

Esta forma de trabalho abriu uma gama de resultados bastante diferente dos conseguidos ou vistos até então. Tornou possível o controle quase total dos efeitos de luz sobre o organdi. A lenta sobreposição das hachuras, tal como no desenho a grafite, é perceptível como uma suave passagem de luz para a sombra, dando ao desenho final uma aparência de estampa, que não explicita à primeira vista a lenta atuação da mão humana em cada um dos desenhos. Essa sensação de absoluta semelhança e presumida reprodução mecânica transmite-se paradoxalmente às rosas, que parecem reforçar essa idéia por estarem associadas ao universo da estamparia de tecidos. 


\section{Por que rosas?}

A figura da rosa - de vários tipos - ocupa exclusiva e integralmente o espaço nos trabalhos dado ao desenho. Esta predileção teve várias origens.

Nos trabalhos anteriores às monotipias-rosas, anteriores, portanto, a 1999, embora já estivessem presentes todos os procedimentos descritos, embora já existisse uma consistente produção de objetos tridimensionais de tecido impressos por monotipia e construídos pela costura, estavam ausentes o desenho, o gesto e consequentemente a matéria e beleza específicas por eles criadas. Ausências estas que pouco a pouco foram se tornando cada vez mais incômodas.

O desenho de observação - realizado a partir da observação de determinado "recorte" da realidade sensível e reprodução o mais aproximada possível das relações espaciais investigadas - teve papel relevante nos anos de formação artística. A preferência sempre foi por estruturas complexas que apresentassem elementos interdependentes e conectados entre si para a busca de uma solução visual que tornasse o objeto escolhido reconhecível e coerente em suas partes.

As rosas justamente ofereciam uma estrutura intrincada e desafiadora para a observação e principalmente respondiam a uma nascente vontade de trabalhar com a idéia de beleza evidente, um conceito de beleza acessível à maioria das pessoas, qualquer que fosse seu nível de cultivo de gosto.

As rosas foram descobertas no universo dos tecidos estampados com motivos florais. A primeira opção foi a de desenhá-los dispostos como panejamento. Nas estampas encontradas as rosas logo se sobressaíram como estruturas e constituíram uma revelação que repercutiu em toda a produção posterior: a beleza evidente, a estrutura rebuscada e a complexidade de luz e sombra que satisfaziam o prazer encontrado no desenho e o interesse gerado pelo dúbio papel decorativo que as imagens de flores receberam na história da arte. 
A respeito da flor, Langer elabora a hipótese de que seja uma forma fundamental, recorrente nas artes decorativas de todos os lugares e todos os tempos:

"Um círculo com um centro marcado e um desenho a emanar do centro sugere uma flor, e essa insinuação é capaz de guiar a composição do artista. Repentinamente, surge um novo efeito, há uma nova criação - uma representação, a ilusão de um objeto" ${ }^{51}$.

Segundo a autora, desse modo, a representação é associada posteriormente à forma inicialmente abstrata, por associação das estruturas ${ }^{52}$. A hipótese, que parece ir de encontro ao modo como a rosa foi descoberta na poética, pode não explicar a fase de sua elaboração como desenho a partir do real num segundo momento, mas um dos motivos inconscientes pelo qual a forma da rosa foi escolhida.

Com a crescente importância que as rosas tomaram no trabalho passei a encontrar na natureza meus próprios modelos, dada a monotonia dos desenhos de estamparia.

A observação do real acrescentou grande interesse aos desenhos. Tanto que as rosas não se ajustavam mais umas às outras para submeterem-se a composições préestabelecidas. Cada monotipia-rosa ganha autonomia, destaca-se, é recortada de seu suporte de tecido e centenas delas são unidas pela costura para plasmar objetos de parede, de chão, de pedestal. Este processo culmina em $2001^{53}$.

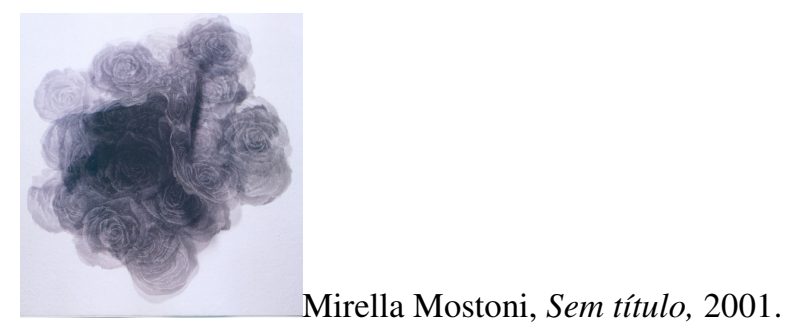

\footnotetext{
${ }^{51}$ Susanne LANGER. Sentimento e Forma.pp.73-74.

${ }^{52}$ Ibidem.pp.73-74.

${ }^{53} \mathrm{O}$ conjunto de doze trabalhos intitulado Sobre Camadas foi exposto no mês de junho na Galeria SESC Paulista.
} 


\section{As etapas do ato criativo ${ }^{54}$}

Aqui serão analisadas as etapas de criação de um trabalho. A seqüência e a estrutura das etapas coincidem tanto na criação de uma única obra, quanto na elaboração de toda uma série ou na idealização de um projeto, desde suas iniciais hipóteses ou imagens mentais até a realização.

A divisão do ato criativo em fases resulta útil para a análise, mas na prática não é um processo contínuo nem as fases apresentam-se isoladamente ${ }^{55}$.

A maneira como esta análise aborda os trabalhos artísticos e o uso que se faz aqui das teorias adaptam-se ao ponto de vista de quem cria. Suas reflexões, seus pontos de chegada preocupam-se exclusivamente com os processos específicos referentes à poética do Conhece-te a ti mesmo e com um entendimento que seja o mais amplo possível daquilo que envolve a sua criação.

Os resultados obtidos nesta reflexão não influenciaram nem influenciam diretamente na criação dos objetos. Foram, contudo, extremamente úteis para uma visão posterior mais abrangente e detalhada de como foi criado cada objeto. Desta forma alcançou-se uma consciência maior do ato criativo em retrospectiva e também uma visão mais nítida de suas possibilidades durante o seu desenrolar.

Esse estudo evidentemente não melhora a qualidade artística final da produção apresentada, mas revela sua utilidade na oportunidade reflexiva que apresenta no que é o cerne deste capítulo: Conhece-te a ti mesmo, isto é, conhecer o subsolo, até onde se conseguir revolver, do próprio trabalho por meio de um pensamento teórico.

\footnotetext{
${ }^{54}$ A análise das etapas baseia-se no texto O Processo Criativo (pp.65-86), quarto capítulo da obra já citada de Julio PLAZA e Mônica TAVARES. A partir de vários autores (WALLAS, MOLES, ARIETI e KNELLER) os autores estabelecem seis etapas de criação: apreensão, preparação, incubação, iluminação, verificação e comunicação.

${ }^{55}$ Jilo PLAZA e Mônica TAVARES. Processos Criativos com os Meios Eletrônicos: Poéticas Digitais.p.73.
} 
Segundo o "princípio da fecundidade", elaborado por Langer, a especificidade do pensamento teórico situa-se para além da mera descrição (pense-se, neste caso, dos procedimentos até o momento relatados desta poética). Está ao alcance deste tipo de pensamento, a partir das implicações nascidas da descrição, ampliar suas conseqüências, podendo-se assim manipular, definir, modificar e usar em combinações as idéias colhidas no primeiro momento de descrição ${ }^{56}$.

Quais são, nesse caso, e como se constituem as etapas do ato criativo de um objeto e até da projeção de uma poética inteira? O que sua análise nos permite desvelar sobre essa mesma poética? Que métodos são usados durante a criação, na conexão entre imaginação e matéria e, como início do percurso proposto, o que é e como pode ser pensada a criação?

\footnotetext{
${ }^{56}$ Susanne LANGER.Op.Cit..p.09.
} 


\section{Sobre o criar e suas causas}

A palavra "criar" deriva do latim creare e significa gerar, formar, fazer surgir algo imerso num processo de "vir a ser" ${ }^{57}$.

As conjecturas sobre as causas do processo criativo remontam a Platão e Aristóteles. De todos os autores consultados, as análises coincidem num aspecto fundamental. Há sempre um paralelismo, uma polaridade entre dois elementos de naturezas diversas que se complementam, que cooperam no ato criativo: a mente e a matéria agem simultaneamente.

Essa correspondência binária traduz-se, conforme a interpretação, no encontro de vários pares: imaginação e matéria; pensamento e movimento ${ }^{58}$; alma e corpo ${ }^{59}$; causa formal e causa motriz ${ }^{60}$; ato mental e práxis; esquemas de pensamento e esquemas de ação ${ }^{61}$.

Os resultados criativos dessa junção traduzem-se numa primeira imagem mental de um possível trabalho artístico e sua posterior figura materializada no mundo sensível, com todas as diferenças e também vantagens e desvantagens que cada uma das duas naturezas lhes conferem ${ }^{62}$.

Há um embate histórico entre duas doutrinas que, desde Platão, procuram entender a natureza da criação artística: de um lado estaria o "milagre do gênio" no qual

\footnotetext{
${ }^{57}$ Não apenas uma obra de arte, mas um fenômeno em geral. Cf. Julio PLAZA e Mônica TAVARES. Processos Criativos com os Meios Eletrônicos: Poéticas Digitais.p.65.

${ }^{58}$ COOMARASWANY.Apud Julio PLAZA e Mônica TAVARES. Op. Cit.pp. 66-67.

${ }^{59}$ Paul VALÉRY. Eupalinos ou O Arquiteto.p.65.

${ }^{60}$ Conceito aristotélico de criação. Cf. Julio PLAZA e Mônica TAVARES. Op. Cit. p.66.

${ }^{61}$ Para os dois últimos pares, ver Mikel DUFRENNE. A Estética e as Ciências da Arte.p. 16

${ }^{62}$ É necessário assinalar as "leis de pensamento" específicas que governam a elaboração da arte como "leis da imaginação". Seria este um tipo de pensamento específico cujas leis diferem e não se aplicam ao raciocínio científico ou prático. Cf. Susanne LANGER Op. Cit. p.244. Gillo Dorfles vê na arte a existência de um "pensar artisticamente", de caráter mais icônico que semântico. Cf. Gillo DORFLES. Elogio da Desarmonia. p.31.
} 
revelar-se-ia a espontaneidade da imprevisível inspiração e, do outro, a sobriedade, traduzindo-se na paciência do trabalho ${ }^{63}$.

Aristóteles distinguiu quatro tipos de causalidades que explicariam todos os fenômenos: material, formal, motriz (ou eficiente) e final. A causa material seria a matéria da qual uma coisa é feita; a causa formal seria o raciocínio, o logos. A causa motriz seria o agente, a ação física que produz o efeito; a causa final, "aquilo pelo qual o efeito é produzido". Para o filósofo as duas primeiras causas coexistem: na matéria como potência, na forma como ato ${ }^{64}$.

Ao contrário dos fenômenos naturais, cuja aplicabilidade das quatro causas pode ser duvidosa, ao se pensar no fazer de um dos objetos do Conhece-te a ti mesmo a associação é clara. A causa material é evidentemente a substância ou o material de que a obra é feita (o tecido, a tinta a linha de costura). A causa formal é o plano que determina a forma do resultado (o projeto, a imagem mental). A causa motriz é a atividade pela qual o resultado foi produzido (o desenhar, o recortar, o costurar e bordar). A causa final é o fim a que essa produção se dirige (a criação artística, uma nova existência).

Segundo Millet o ato de criar é uma construção, sempre dinâmica, na condição de sempre poder vir a ser, cujas quatro causas traduzem-se respectivamente na conjunção do suporte com o pensamento criador que, por meio da ação física, geram um produto acabado ${ }^{65}$.

Se para Aristóteles as causas material e formal estariam juntas, para Coomaraswany existe uma relação de sinergia entre as causas formal (intelecto) e motriz (mãos) na produção artística. Nela ocorre o trabalho simultâneo do intelecto e das mãos, o envolvimento das faculdades imaginativa e operativa. A segunda

\footnotetext{
${ }^{63}$ No século XX esta oposição sobrevive no debate entre as idéias da criação como atitude espiritual de uma personalidade (teóricos da Einfühlung e Croce) e, na outra ponta, a idéia de que o criador não preexiste ao seu ato, cria-se a si próprio (Valéry e Alain). Cf. Mikel DUFRENNE. Op.Cit. p. 20. ${ }^{64}$ Aristóteles Apud Julio PLAZA e Mônica TAVARES. Op.Cit. p.65.

${ }^{65}$ Julio PLAZA e Mõnica TAVARES. Op.Cit. p.65.
} 
caracteriza-se pela atuação do método, é a imitação do movimento numa determinada matéria ${ }^{66}$.

Podemos dizer que há, no ato da criação, conjunção entre pensamento e matéria. A matéria do criador, além da que manipula, incluiria mãos e corpo, compartilhando os três da mesma natureza. No diálogo com Sócrates, em Eupalinos, Fedro, o construtor, tenta descrever ao filósofo como se sente ao criar, ao construir: "me parece entranhar-se na obra todo o meu corpo" ${ }^{67}$. No corpo humano Fedro reconhece a medida do mundo através da proporção das partes e vê a propriedade de vida deste, mesmo que perecível, indispensável à criação, por ser matéria que dela faz parte.

Nas palavras dos personagens lemos a concepção de Valéry, que retorna às categorias aristotélicas, considerando interdependentes as causas formal e motriz: no criador unem-se alma e corpo. O pensamento, a fantasia, o intelecto da alma ao juntarem-se ao corpo e à matéria no ato da criação, unem-se também sonho e vida, fantasia e potência, pensamento e movimento ${ }^{68}$.

A estreita proximidade entre o trabalho da mente e das mãos na fatura de uma obra de arte também encontra confirmação em Langer quando esta afirma que :

"Toda articulação é difícil, minuciosa e engenhosa; o fazimento de um símbolo exige habilidade tão verdadeira quanto a feitura de um vaso adequado ou um remo eficiente" ${ }^{69}$.

Em relação à linguagem usada pelo artista - a técnica - é aprendida por meio de exemplos, prática e treinamento, o que torna ofício toda elaboração de uma forma expressiva $^{70}$.

A experiência do Conhece-te a ti mesmo e da poética que o precede coincide com essas reflexões. É nelas intensa a idéia da afirmação da mão humana, do trabalho

\footnotetext{
${ }^{66}$ Ibidem.p.66.

${ }^{67}$ Paul VALÉRY. Op.Cit.p.51.

${ }^{68}$ Ibidem.pp.65-69. Grifo da autora.

${ }^{69}$ Susanne LANGER. Op.Cit.p.41.

${ }^{70}$ Ibidem.p.41.
} 
artesanal paciente que interliga fortemente o pensamento operativo ao imaginativo e que se remete à antiga equivalência entre as palavras tékhne e ars $^{71}$.

\footnotetext{
${ }^{71}$ Para Aristóteles as duas palavras encontravam-se no mesmo âmbito semântico. Se habitualmente distinguimos a técnica da arte e da ciência, para o filósofo tékhne referia-se a qualquer forma de produção.Era um meio para se atingir um fim e a ela associava-se um saber. Cf. Gianni CARCHIA e Paolo D'ANGELO. Dicionário de Estética.p.339.
} 


\section{Primeira etapa: Apreensão}

É a noção de que se tem algo a executar, de que se tem um problema a ser resolvido. Embora angustiante, é o estímulo e o impulso para a criação, no qual sentese a necessidade de se buscar a novidade ${ }^{72}$.

A necessidade de se fazer algo novo pode ocorrer na passagem de um trabalho para o outro dentro de uma mesma série ou na passagem de um ciclo de produção de todo um conjunto de trabalhos que pode ter durado muito tempo para o encontro de um novo desafio.

A apreensão é identificável pelo retorno da pergunta sobre como continuar a próxima peça, um projeto novo ou se os procedimentos usados até o momento continuam válidos.

Antes de chegar na construção dos objetos com monotipias-rosas (antes, portanto, de 1999) manifestou-se como a vontade difusa sem razões aparentes de incluir-se o desenho de observação e fazer algo explicitamente belo nos trabalhos vindouros.

A apreensão que precedeu a elaboração do projeto de mestrado deu-se a partir de 2001, ano em que a pesquisa anterior, a qual utilizava os mesmos procedimentos depois retomados no Conhece-te a ti mesmo, culminou numa exposição que encerrou a pesquisa. Criou-se naquele momento uma característica sensação de vácuo. Como continuar sem se repetir?

\footnotetext{
${ }^{72}$ Julio PLAZA e Mônica TAVARES. Op.Cit. p.74.
} 


\section{Segunda etapa: Preparação}

Nesta etapa, quando já se assimilou o conhecido, a mente se prepara, perambula. Sucedem-se nesta ordem as ações que investigam as possibilidades, que experimentam e pesquisam o meio produtivo ${ }^{73}$.

Esta fase manifesta-se sob dois aspectos: em parte na pesquisa técnica e em parte apresentando-se como uma disposição mental aberta a novos estímulos. Há uma sensação constante da presença de uma pergunta específica que se revelaria decisiva para o encaminhamento do trabalho, mas ainda sem clareza.

Antes de iniciar-se um novo trabalho pertencente a uma série cujos procedimentos ainda não se pretende mudar, esta etapa apresenta-se como a procura mental por uma nova forma, num ato que "deixa surgir" hipóteses visuais daquilo que pode vir a ser.

Após uma série que se esgota a preparação é uma sensação de abertura da "caixa preta" das idéias norteadoras da fase que se encerra. O conjunto dos procedimentos pesquisados e aprimorados entra repentinamente em crise, tem seus mecanismos afrouxados, abertos, o que permite a chegada do novo e uma desejada modificação ${ }^{74}$.

Nesta fase aguça-se uma insatisfação com os meios técnicos antes usados com proveito. Por exemplo, o desagrado com os resultados da monotipia sobre papel que antecedeu a pesquisa com o tecido; a gradativa rejeição das cores usadas na monotipia até restar somente o preto.

\footnotetext{
${ }_{74}^{73}$ Julio PLAZA e Mônica TAVARES.Op.Cit. p.74.

${ }^{74}$ A pesquisa de meios novos ou modificados tem a finalidade de domínio da técnica, aprendizado necessário nesta fase, pois "para se criar se requer técinca". Cf. Julio PLAZA e Mônica TAVARES. Ibidem.p.74.
} 
Faz parte da preparação abandonar momentaneamente a produção e o exercício dos meios técnicos já dominados para permitir a incorporação de outros meios através de outro tipo de estímulo (a leitura, por exemplo) e atentar para elementos do mundo circundante antes excluídos do desenvolvimento da poética. Neste caso, isto manifestou-se no desenho de observação de tecidos florais estampados dispostos como panejamento. Essa experimentação originou tanto experiências sem prosseguimento quanto trabalhos acabados e autônomos.

Mirella Mostoni, Sem título, 1999. 


\section{Terceira etapa: Incubação}

A incubação era o sono em locais sagrados para a obtenção de um sonho revelador concedido por uma divindade. Era uma das principais e mais antigas práticas divinatórias ${ }^{75}$. Esta origem traduz adequadamente a natureza desse momento, no qual um aparente sono revela a pouca ou nenhuma influência da consciência na obtenção da imagem mental que resolve as apreensões criativas. É um período onde os passos decisivos são dados no escuro e em silêncio.

É uma fase de busca. É premente nela a sensação de que falta pouco para se atingir e completar a idéia. As conexões procuradas para este encontro são inesperadas, pois a inteligência - em estado de "liberdade, disponibilidade e abertura" - configura a obra inconscientemente ${ }^{76}$. Desta forma:

"Ou se iniciam várias atividades sem necessariamente as terminar, partindo-se constantemente para outras; ou se estabelece um estágio de relaxamento mental, de passividade intelectual." 77 .

A insatisfação da fase anterior com o papel como suporte para a monotipia e com os desenhos de rosas nas estampas florais disponíveis no mercado provocam experimentações, tentativas e erros.

Nesse momento a monotipia foi o único elemento preservado da produção antecedente e o único invariável no processo, alimentando a busca pelo suporte e pelo desenho ideal.

O desenho de observação, mesmo sem mudar a temática - a rosa -- muda radicalmente a imagem de referência e os esquemas mentais acionados para o desenho, que passa da observação do bidimensional - padrões de rosas -- para o tridimensional as rosas observadas --, incorporando soluções gráficas oriundas de ambas as fontes.

\footnotetext{
${ }^{75}$ Pierre LAVEDAN. Dictionnaire Illustré de la Mythologie et des Antiquités Grcques et Romaines.p.542.

${ }^{77}$ Julio PLAZA e Mônica TAVARES. Op. Cit. p.74.

${ }^{77}$ Ibidem.p. 74 .
} 
A incubação de um trabalho concatenado numa série revela-se primeiro pelo aparecimento de rápidas imagens mentais de possíveis novos trabalhos. Um ensaio para a iluminação propriamente dita, pois é concomitante a sensação de que são idéias ainda incompletas, não amadurecidas.

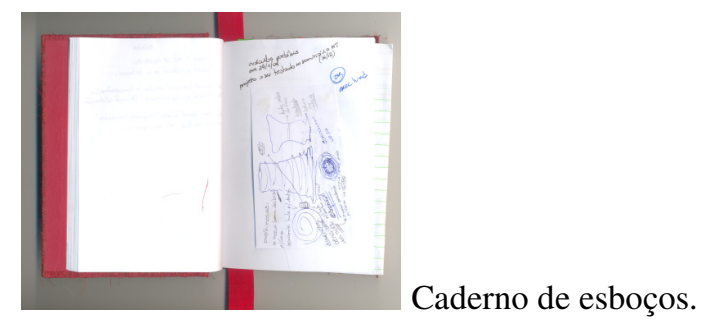

Esta é a fase dos desenhos preparatórios que anotam as imagens surgidas para posteriores reavaliações ou modificações. As idéias registradas desta forma são raramente realizadas, mas os processos de reflexão e eventual experimentação disparados são decisivos para pavimentar o caminho que leva ao insight, claramente percebido então como solução definitiva.

A fase de incubação do Conhece-te a ti mesmo caracterizou-se pela presença da sentença do oráculo de Delfos, sobrestante às apreensões, que incomodava sem encontrar, contudo, uma porta de entrada para que fizesse parte do trabalho artístico. Uma porta difícil de ser aberta, já que até aquele momento este último sempre foi mantido distanciado da palavra, sequer apresentando titulação nas peças.

Essa percepção específica em relação à palavra assemelha-se em parte a um conceito elaborado por Dorfles. O autor refere-se ao conceito criativo de inner speech, que seria um "pensamento falado" mas ainda não expresso nos termos da linguagem. Um tipo de pensamento a meio caminho entre a palavra e o pensamento visual que se caracterizaria por palavras precisas que se agitam na mente ${ }^{78}$. Como era o caso da sentença délfica ainda sem uma definição de uso num trabalho ainda em formação.

\footnotetext{
${ }^{78}$ Gillo DORFLES. Elogio da Desarmonia.p.44. (grifo da autora).
} 


\section{Quarta etapa: Iluminação}

É o insight criativo. Momento crucial e instantâneo da criação, sua principal característica é apresentar a solução sob uma configuração eminentemente visual, nãoverbal $^{79}$.

A definição da palavra insight é a de uma clareza repentina na mente.É a resolução de um problema que se dá pela repentina captação mental das relações adequadas à solução, que é nova em relação a experiências anteriores ${ }^{80}$.

A sensação é de que a solução, pronta em seus aspectos decisivos, emerge da movimentação indistinta do momento da incubação ${ }^{81}$.

A iluminação ao se criar um objeto (pertencente a um já iniciado conjunto de trabalhos, e, portanto, com algumas leis sintáticas já definidas, ou mesmo novo em sua maior parte) está ligada à visualização mental constante de uma solução ${ }^{82}$, repetida seguidas vezes na fase da incubação.

A quarta etapa culmina com o claro aparecimento de uma imagem mental. A próxima obra revela-se por inteiro como se estivesse finalizada. Interpreta-se aqui "imagem" como a figuração sensível, ainda mental, de algo que se tornará um objeto, diferente daquela.

Segundo Sartre é comum que o artista parta de uma imagem mental incomunicável e produza, a partir dela, um objeto dado à contemplação. O autor

\footnotetext{
${ }^{79}$ Julio PLAZA e Mônica TAVARES. Op.Cit.p.75.

${ }^{80}$ Antonio HOUAISS. Dicionário Houaiss da Lingua Portuguesa.p.1624.

${ }^{81} \mathrm{O}$ insight liga-se ao conceito de raciocínio abdutivo de Peirce: "uma sugestão de que algo pode ser". O momento da iluminação é por ele definido como "uma associação por semelhança", pois sua forma final é análoga ao nódulo do problema resolvido. No pensamento abdutivo os fatos sugerem a hipótese por meio desse tipo de associação, constituindo o cerne do fenômeno da iluminação. Cf. Julio PLAZA e Mônica TAVARES. Op. Cit.pp.76-77.

${ }^{82}$ Esta ação caracteriza um dos métodos heurísticos de criação, o do projeto, discutidos mais adiante.
} 
assinala, porém, a diferença que sempre separará o imaginário do real: o objeto estético não coincide com o objeto físico, é um analogon material da imagem mental ${ }^{83}$.

$\mathrm{O}$ autor classifica esse aparecimento de imagens mentais como um tipo de pensamento da consciência imaginante. $\mathrm{O}$ desenvolvimento de uma idéia por imagens pode mostrar a imagem mental sob vários aspectos:

" (...) ele produzirá para o objeto enquanto imagem uma espécie de vida" ${ }^{84}$.

Nesse período continua o registro concreto dos objetos imaginados, via desenhos preparatórios e descrições textuais detalhadas de formas e procedimentos. Estas anotações diferenciam-se de outras anteriores por partirem de uma idéia-imagem que se apresenta com um forte aspecto de concretude e viabilidade. Desta forma, os desenhos e os textos descritivos não figuram hipóteses ainda incertas, mas testam possibilidades e soluções práticas girando em torno de apenas uma idéia.

A iluminação da fase anterior ao Conhece-te a ti mesmo chegou a seus procedimentos característicos não só pela projeção mental, mas também por meio das experimentações técnicas, tentativas e erros da incubação, fase na qual há também produção artística. O ganho de autonomia das monotipias-rosas que permitiu a imaginação de muitos objetos foi uma iluminação proveniente do trabalho com a monotipia e o aprofundamento do desenho de observação. A iluminação se fez, portanto, na sequiência da produção dos objetos: alguns autônomos como obras, alguns insatisfatórios e, por esta razão, reveladores de que o caminho deveria se modificar.

Até o momento descrito as monotipias sobre organdi eram tratadas com um desenho único e a construção de um objeto usava uma área contínua de tecido, dobrando-o e moldando-o em alguns casos. Ao ser descoberto o interesse pela rosa

\footnotetext{
${ }^{83}$ Jean-Paul SARTRE. O Imaginário.p. 246.

${ }^{84}$ Ibidem.p.150.
} 
natural observada, formou-se decididamente a matéria-prima essencial dos trabalhos seguintes ${ }^{85}$.

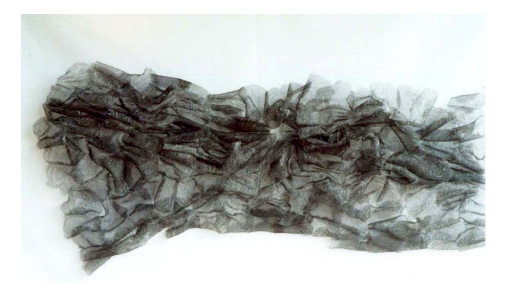

Mirella Mostoni, Sem título,2001.

A chegada ao insight e a construção de sua matéria deu-se primeiro por vias diretamente ligadas à produção dos objetos. Seja por seus procedimentos técnicos, seja pela imaginação, seja inclusive pela palavra, que ao descrever o planejamento num alto nível de detalhamento também o configura (muitas vezes de forma mais eficiente que o desenho).

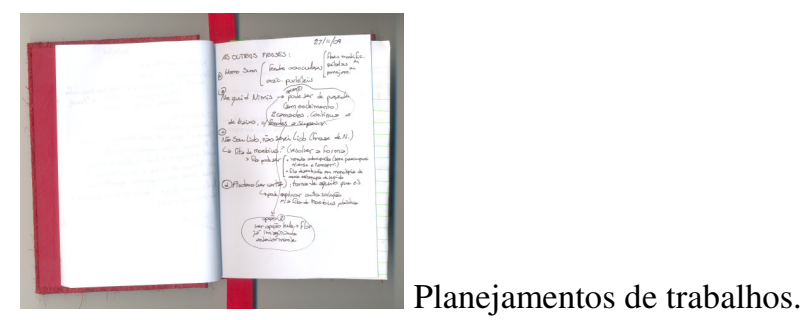

Há um outro aspecto ativo da palavra na formação do insight que é o seu recebimento e transformação: a leitura. O encontro com $O$ Nascimento da Tragédia trouxe a segurança de que faria sentido propor o oráculo como uma metáfora da relação entre espectador e obra unida à vontade de apresentar uma beleza evidente nos trabalhos. Estão presentes na obra de Nietzsche, tratados filosoficamente, os mesmos elementos contemplados pela poética: a beleza como elemento da arte, o oráculo de Apolo, suas frases admoestatórias e a complexa relação destas com a condição humana.

\footnotetext{
${ }^{85}$ Segundo Kneller é justamente no momento da iluminação que "surge a matéria-prima da realização criadora". Cf. Julio PLAZA e Mônica TAVARES. Op.Cit.p.75.
} 


\section{Quinta etapa: Verificação}

É a fase da realização. Passível de controle, engloba um processo de revisão no qual a idéia é conscientemente elaborada. Fase de possíveis correções de rumos, onde o problema é retomado, verifica-se a satisfação com a solução, onde caminhos podem ser mudados podendo-se inclusive retornar à incubação ${ }^{86}$.

Nesta etapa ocorre a síntese entre o espontâneo e o consciente, complementamse reciprocamente a intuição e o intelecto, "quando o julgamento termina a obra que a imaginação começou" ${ }^{87}$. Logo, alternam-se a realização concreta da idéia com um afastamento que julga e decide a continuidade desta.

É uma etapa de dúvidas, resoluções, pontos de partida na qual se utiliza o repertório de elementos materiais e se exercita o domínio técnico como conhecimento construído para "organizar um código semântico capaz de estabelecer a comunicação ou o possível significado" ${ }^{88}$, isto é: construir de fato a obra e verificar se suas soluções realizam satisfatoriamente a imagem mental surgida na iluminação.

A verificação num novo trabalho cujos procedimentos já estão dominados concentra-se na montagem do objeto tridimensional. É o momento de se decidir que soluções técnicas, que "engenharia" de costura sustentará a forma planejada, meio essencial da construção. Num segundo momento verificam-se os meios ideais de montagem dos trabalhos prontos para o espaço expositivo.

Para os trabalhos do Conhece-te a ti mesmo, além dos processos de verificação já mencionados, testou-se a adequação do bordado e seus efeitos sobre o organdi; testou-se, além disso, a eficiência das peças enquanto oráculos, a legibilidade das

\footnotetext{
${ }^{86}$ Julio PLAZA e Mônica TAVARES. Op.Cit. p.82.

${ }^{87}$ Ibidem.p.82.

${ }^{88}$ Ibidem.p.84.
} 
sentenças, se de fato as peças convidam à investigação visual e à leitura da palavra, o que influirá decisivamente na próxima etapa. 


\section{Sexta etapa: Comunicação}

Para quem cria, nesta etapa tornam-se visíveis ou não, eficientes ou não todas as medidas tomadas nas fases anteriores. Ocorre aqui a acumulação do que foi feito antes, mas é limitada a atuação do artista neste momento. Essa fase parece pertencer ao espectador, que põe à prova as expectativas que o criador conseguiu ou não concretizar na obra.

A preocupação de quem cria, neste caso, é a de se serão compreensíveis as intenções de sentido projetadas pelo artista para seus possíveis espectadores. Para o Conhece-te a ti mesmo, é necessário que se mostre, após alguma investigação visual por parte do espectador, o percurso de leitura formado pela palavra: a combinação e seqüência do título geral, dos títulos das peças e das sentenças nelas bordadas, complementando-se reciprocamente os sentidos formados com os objetos de monotipias-rosas.

É preciso que o percurso realizado pelo espectador situe-se no melhor equilíbrio possível entre o velamento e o desvendamento de significados, tornando-se estes múltiplos na leitura da obra e que possam, pelo menos no que é essencial, coincidir com a expectativa da artista.

A comunicação é a inserção do criativo no domínio público. Separa-se a obra do criador e esta "põe-se a viver sujeita às críticas e regras impostas por uma sociedade" ${ }^{89}$. Nessa fase distinguem-se a "mensagem" de cunho pessoal e a "significação" que se destina à inserção social, situação a partir da qual devem ser discutidas as implicações da obra. Na etapa da comunicação evidencia-se a co-criação do espectador contemporâneo e entra-se no território da recepção.

\footnotetext{
${ }^{89}$ Ibidem.p.86.
} 
Além da questão dialética entre obra e espectador contida na metáfora oracular, há algumas significações presentes no modo artesanal de produção, na escolha da rosa como único elemento figurativo - a qual remete tanto ao mundo sensível quanto à história da arte - e da beleza explicitamente procurada na aparência final.

A escolha da imagem da rosa reenvia à longa história das flores na arte. Desde os antigos desenhos de rosetas que se originam quase de seu próprio movimento circular arquetípico e não da observação do natural ${ }^{90}$. As rosas estão constantemente presentes de alguns anos para cá na moda, na indústria têxtil e na pintura decorativa. A percepção desse fenômeno coincide com a época de sua escolha como temas para a observação.

O ponto de partida para toda a poética foi um encantamento com uma forma sugerida pelo ambiente e confirmada pelo gosto pessoal. Em torno dessa escolha, precedendo-a ou sucedendo-a, giram em seu entorno alguns elementos da poética: a delicadeza do resultado que evoca inegavelmente um trabalho feminino e apresenta como conseqüência a forte conotação tátil dos objetos; o enfoque na bela aparência que evoca um tipo de contemplação da imagem definido por Schiller (Schein), cuja visão:

"Libera a percepção (...) de todas a finalidades práticas e deixa que a mente habite na pura aparência das coisas" ${ }^{91}$.

\footnotetext{
${ }^{90}$ Hipótese já apresentada de Susanne LANGER. Cf. Op.Cit.pp.73-74.

${ }^{91}$ Friderich SCHILLER. Apud Susanne LANGER. Op.Cit.p.51. Schelling, Friedrich Wilhelm Joseph von. Leonberg, 1777 - Bad Ragaz, 1854.
} 


\section{Conhece-te a ti mesmo sob o ponto de vista dos métodos heurísticos de criação}

A idéia essencial desta pesquisa fundamentou-se num único ponto de partida: o trabalho artístico apresentando-se como oráculo e oferecendo ao seu espectador uma única e reiterada resposta: Homo sum.

Porém, desde o momento do planejamento, da fase inicial de feitura e seu posterior desenvolvimento o Conhece-te a ti mesmo afirma-se como um conjunto de trabalhos dividido em três séries, compostas por três peças as duas primeiras e por quatro a última.

A opção evidente de pesquisa é por um alargamento das possibilidades e não por um máximo aprofundamento de uma única questão. Multiplicaram-se as configurações planejadas dos objetos, assim como as respostas oferecidas e, conseqüentemente, multifacetaram-se as formas pelas quais um oráculo pode vir a ser.

Há a representação bidimensional de fendas sobre a terra em relação direta com a narrativa da tradição délfica. Há também a representação de uma cavidade independente do chão e passível de deslocamento. Há uma forma de oráculo que até mesmo veste seu espectador, que com ele se comunica pelo contato direto com o corpo, variando a partir dessas formas também as respostas oraculares.

Um dos principais métodos ${ }^{92}$ de criação artística utilizados no Conhece-te a ti mesmo, causa inclusive do desdobramento dos oráculos, foi o de partir de uma idéia de

\footnotetext{
92 Entende-se aqui por método os métodos heurísticos de criação elaborados e analisados em texto homônimo de Plaza e Tavares. Palavra derivada do grego méthodos, este conceito denota o caminho (não necessariamente determinado ou refletido) pelo qual se chega a um resultado. É um processo mental que fabrica as descobertas e invenções. Na arte, este caminho reúne a forma da invenção e a maneira de fazêla. Os onze métodos possíveis de serem utilizados durante a criação de uma obra de arte dividem-se em três categorias. A categoria do possível engloba os métodos do possível; do projeto; cibernético; do acaso; da matriz do descobrimento; dos limites; por associação. A categoria do existente compõe-se dos métodos do experimental e da redução fenomenológica. A categoria do pensamento apresenta os métodos da recodificação; mitopoético e paradigmático. Serão instrumento de análise nesta dissertação apenas os
} 
oráculo, um plano inicial de um objeto testando ao máximo - mentalmente, concretamente ou ambos - uma parte considerada relevante dos seus possíveis desdobramentos.

Tentava-se dessa forma fazer com que cada novo trabalho constituísse não apenas uma variação do original, mas que revelasse uma faceta insuspeitada da idéia fundamental e enriquecesse o resultado do conjunto.

Poucos trabalhos, para qualquer artista, nascem e vivem individualmente. A tentativa é fazer com que sempre inaugurem ou aprofundem uma idéia. Esta tentativa traduz a chance de sobrevivência do trabalho feito que, dando início a uma série a partir de si ou fazendo parte de uma, encontre sempre novas significações consistentes.

Esta forma de desenvolver um conjunto de trabalhos coincide com um dos métodos heurísticos de criação: o método da matriz do descobrimento. Caracteriza-se por produzir soluções múltiplas nascidas de uma primeira idéia geradora. É uma:

"Idéia alimentada pelas combinações de elementos que dá lugar a uma quantidade de realizações todas diferentes na sua materialidade, mas participando do mesmo sistema de pensamento" ${ }^{93}$.

É importante assinalar que os frutos desse método renovam o elemento previsível da matriz, já nela contido, mas oposto à idéia de cópia ${ }^{94}$.

É comum já durante a fase de desenhos preparatórios o surgimento de desdobramentos procedentes de variações da forma original, que podem ser a inversão das posições dadas ao branco e ao preto, uma mudança na técnica, o aumento das dimensões, a modificação da forma de exposição do objeto finalizado.

Esses desdobramentos obedecem à vontade de exaurir todas as possibilidades que uma "forma-mãe" pode oferecer. Nem todos são concretizados, pois o sentido para

métodos inerentes à poética do Conhece-te a ti mesmo. Cf. Julio PLAZA e Mônica TAVARES. Os Métodos Heurísticos de Criação. pp.87-115.

93 Abraham MOLES. Apud Julio PLAZA e Mônica TAVARES. Op.Cit.p. 96.

${ }^{94}$ Abraham MOLES. Apud Ibidem.p.96. 
as suas existências não depende da vontade de variação, o que acarretaria o risco de atingir-se uma desnecessária redundância do trabalho, mas sim das significações que pretendem atingir, significações projetadas para futuros trabalhos que muitas vezes manifestam-se inesperada e prematuramente em peças já realizadas.

Alguns elementos caracterizam um certo número de trabalhos como uma série mesmo que elaborados dentro de um conjunto maior com uma única proposta.

Em primeiro lugar está certamente o modo de planejá-los. A idéia dos trabalhos seguintes surge de um primeiro cujas potencialidades multiplicam-se depois nos objetos que o seguem, tal como descrito anteriormente.

A idéia surgida como imagem mental neste ponto do processo criativo e posteriormente concretizada em objeto evidencia o uso do método do projeto.

Neste método chega-se ao insight partindo-se de uma idéia, uma estrutura mental ordenada ${ }^{95}$. A tentativa de construção do objeto, a verificação concreta de sua viabilidade ocorre a partir da ocorrência dessa imagem mental que o vê pronto, completo.

Para que isso ocorra é importante assinalar que as leis sintáticas e os meios produtivos necessários já devem estar estabelecidos ${ }^{96}$. Já se deve ter chegado a eles por experimentações anteriores ou por uma prática estabelecida, para que durante a construção do objeto - a ação dominante neste tipo de método heurístico - realize-se o compromisso entre o instrumental disponível e o projeto prévio ${ }^{97}$.

Evidentemente podem ocorrer imagens mentais de objetos cujos procedimentos de construção sejam desconhecidos, mas o projeto de um trabalho só ganha viabilidade e pleno domínio de seu planejamento quando os procedimentos já estiverem dominados.

\footnotetext{
95 Julio PLAZA e Mônica TAVARES. Op.Cit..p.90.

${ }^{96}$ Ibidem.p. 90.

${ }^{97}$ Ibidem.p.90.
} 
Neste caso, necessita-se de ensaios para se chegar a um caminho suficientemente claro, trabalhando-se com outros três métodos: o dos limites, o experimental e o método do acaso.

O método dos limites procura ultrapassar os limites impostos por procedimentos muito dominados ou já esgotados para criar novas formas. Explora as regras estabelecidas num projeto, reconhece suas fronteiras e tenta transgredi-las ${ }^{98}$.

Na prática ocorre quando uma produção esgota-se ou começa a repetir-se, manifesta-se como uma possibilidade presente todo o tempo de superar um problema reconhecível e inaugurar uma nova fase do trabalho, como no momento da incorporação da palavra na poética, a procura por suportes diferentes do papel e, principalmente, a exploração de um grafismo sutil em técnicas já dominadas de monotipia, que obteve resultados insuspeitados.

Colaboram diretamente na superação dos limites os métodos do acaso e do experimental. A atuação desses métodos é claramente demonstrada pelos seus nomes. Não atuam como metodologias principais na elaboração de um trabalho, são utilizadas mais comumente em momentos de transição entre um trabalho e outro, entre uma fase da poética e outra.

O método do acaso incorpora o imprevisto produzindo o fato único, integra eventos não dominados e inesperados ${ }^{99}$. Seus resultados incontroláveis manifestam-se na monotipia como acidentes isolados (geralmente como um efeito ou "defeito" na impressão) possivelmente bem-vindo, mas irrepetível como procedimento futuro.

\footnotetext{
${ }^{98}$ Ibidem.p.97.

${ }^{99}$ Ibidem.p.93.
} 
No método experimental vai-se da prática para a teoria. Realiza-se diretamente um produto, de forma lúdica, sem se estabelecer objetivos: é a "experiência para ver no que dá" ${ }^{100}$.

O principal caráter que distingue uma série é então a exploração em várias frentes de uma idéia inicial. As conseqüências para os trabalhos que constituem a série são, primeiro, soluções formais que, embora diferentes, expressam uma identidade que as une. A característica seguinte é a máxima investigação das possibilidades de construção e, por fim, o tipo de solicitação proposta ao espectador.

Um exemplo da aplicação do método da matriz do descobrimento foi a construção dos dois Oráculos Portáteis que se acomodam sobre os tripés. Ambos assemelham-se bastante.

A idéia original era a de obter a cavidade na qual se lê a sentença de Terêncio sobrepondo-se círculos concêntricos compostos por rosas parcialmente sobrepostas e costuradas. O trabalho apresentaria uma ordem de tamanhos de círculos decrescentes da base para o topo ${ }^{101}$, o que acarretou imediatamente a hipótese de se verificar o resultado numa situação de círculos decrescentes ${ }^{102}$. A terceira idéia derivada seria a de um objeto que apresentasse círculos de diâmetro constante, descartada na etapa da verificação por apresentar pouco interesse formal e tornar a série redundante.

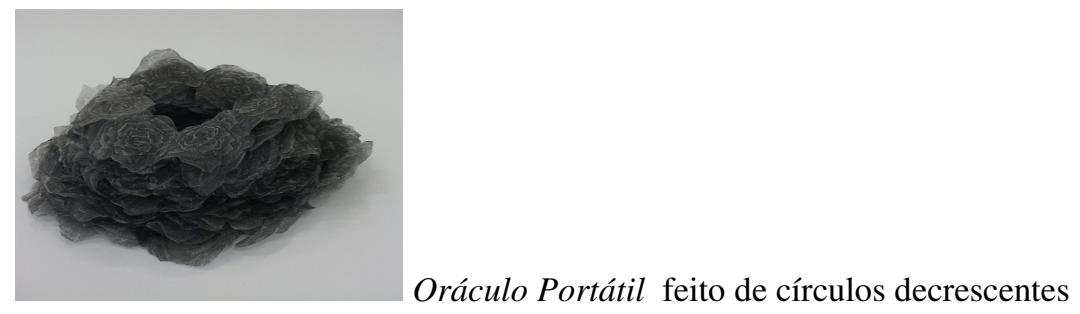

\footnotetext{
${ }^{100}$ Ibidem.p.103.

${ }^{101}$ Projeto que originou oOráculo Portátil, 2005. Bordado sobre tule, monotipia sobre organdi recortado e costurado, 9 × $30 \times 38 \mathrm{~cm}$.

${ }^{102}$ Projeto que originou o Oráculo Portátil, 2005. Bordado sobre tule, monotipia sobre organdi recortado e costurado, $6 \times 43 \times 47 \mathrm{~cm}$.
} 


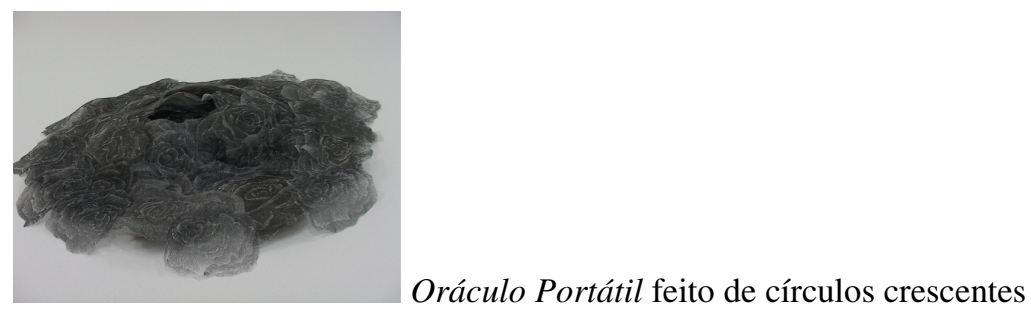

O terceiro Oráculo Portátil (Non legor, non legar) não parte do mesmo método construtivo, mas está claramente irmanado aos anteriores sob as perspectivas de três idéias características: a cavidade; a montagem - os três apresentam-se suspensos do chão de formas diferentes; a solicitação ao espectador - todos pedem um olhar que os investigue de cima para baixo e percorra o interior da peça.

Se até o momento refletiu-se sobre as qualidades em comum que tornam alguns trabalhos uma série, é necessário agora refletir sobre os motivos inerentes à poética que levaram à subdivisão dos dez trabalhos que compõem o Conhece-te a ti mesmo em três séries diferentes e à sua união como um só conjunto.

Esse processo de ramificação englobou quatro operações: ampliar, aprofundar, repetir e sintetizar.

Há uma tentativa de equilíbrio entre a ampliação, por um lado, e o aprofundamento, por outro, da metáfora de oráculo em cada série. A idéia expandiu-se horizontalmente gerando três tipos de oráculos e aprofundou-se verticalmente no desdobramento formal de cada tipo.

Entre repetir e sintetizar existe aparentemente um paradoxo. Por mais que se diferenciem entre si os trabalhos integrantes de uma série, tende-se de fato a reiterar neles o sentido essencial da metáfora. A síntese encontrar-se-ia, portanto, na mirada do conjunto do Conhece-te a ti mesmo, no qual os sentidos autônomos de cada peça complementam-se ao ganhar novas significações por meio da subordinação ao todo. 
As três séries de oráculos trazem em comum uma determinada proposição de leitura para o espectador: ler a palavra na obra e ler a obra também por meio da palavra. Propõem ao espectador um duplo papel de contemplador e leitor ${ }^{103}$.

Todos têm em comum o modo como a palavra manifesta-se para seu leitor, visual e verbalmente. No primeiro aspecto, tanto no modo como é inscrita no trabalho, lentamente, bordada ou desenhada, como em sua origem formal, proveniente de manuais de caligrafia. Verbalmente, os sentidos das palavras constroem um todo apresentando-se como sentenças, clássicas ou não, originárias de diferentes épocas e autores.

${ }^{103}$ Louis MARIN. Sublime Poussin.p.28. 


\section{As Fendas Oraculares}

São quatro monotipias de grandes dimensões ${ }^{104}$ se comparadas às monotipiasrosas da maioria dos trabalhos. Compõem-se de partes de rosas sobrepostas parcialmente em poucas camadas, conservando assim um caráter bidimensional. Todas trazem bordada em suas superfícies a inscrição Homo sum.

Os desenhos de base para as monotipias-rosas provêm do desenho de observação de flores naturais, como já descrito anteriormente. Essa operação pôs em prática vários tamanhos e formatos e, com o desenvolvimento de alguns trabalhos seminais que remontam ao início das pesquisas da poética em 1999, terminou por selecionar um certo número de desenhos de rosas de tamanhos semelhantes entre si.

Embora o resultado da monotipia manifeste-se de forma sempre renovada o repertório dos desenhos-base não muda, permanece praticamente o mesmo desde o início das pesquisas. As rosas são apenas selecionadas para que um ou outro tipo formal predomine conforme o planejamento dos objetos.

São vinte e oito desenhos de rosas, registrados com esferográfica sobre um tecido de algodão, portanto sempre disponíveis para o decalque sem modificações relevantes do desenho, de forma semelhante ao processo de decalque de moldes na costura. Sobre a matriz de tecido, fixa-se o organdi transparente com alfinetes e, com um lápis, reproduzem-se os contornos das rosas. Para cada rosa, um novo contorno.

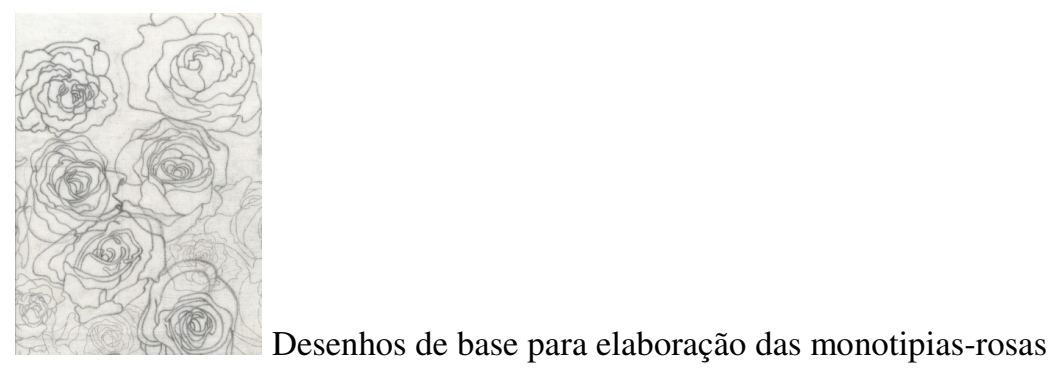

\footnotetext{
${ }^{104}$ Todas as quatro elaboradas com bordados sobre monotipias impressas sobre organdi recortado e costurado, 2005. Dimensões: 155 x 82 cm.; 114 x 123 cm.; 85 x 87 cm.; 77 x 98 cm.
} 
Algumas mudanças nos desenhos de base para os desenhos finais no organdi ocorriam ocasional e sutilmente antes da elaboração das Fendas Oraculares. Limitavam-se, quando necessário, a uma pequena ampliação das dimensões das flores, a um aumento ou diminuição de determinadas pétalas, em função da construção do objeto final.

Mostra-se aqui o método heurístico dos limites atuando nos hábitos que se instalam na execução de uma poética. Por que as rosas, a matéria-prima, não poderiam mudar e o que aconteceria se mudassem?

O insight inicial de se produzir o primeiro oráculo nasceu imaginando-se uma monotipia de tecido sobre o chão, não figurativa, que mimetizasse por meio do grafismo a aparência de um buraco. Daí a substituir a forma inicial pela idéia de uma grande rosa que não fosse facilmente reconhecível como tal foi um pequeno passo.

A partir desse momento, submetendo os novos materiais escolhidos a experimentações, são realizadas cópias dos já bem conhecidos desenhos de rosas sobre um tecido de grande elasticidade. Com a ajuda de uma mesa de luz sob o tecido registram-se no papel a ele sobreposto as intensas deformações a que são submetidos os desenhos.

Esse processo não seguiu nenhum critério pré-estabelecido de deformação. Apenas o interesse plástico maior ou menor que as novas formas eram capazes de assumir. Essa seqüência de ações incorporou o imprevisível, encontrando por meio das experimentações e do acaso as melhores combinações entre as deformações e as rosas que melhor se prestaram a esse efeito.

Os resultados formais mais interessantes foram os desenhos mais alongados, já distanciados da simples denotação de buraco, mas apresentando novas qualidades, mais 
próximos de uma aparência de fendas. Redireciona-se desta forma o conceito do trabalho e aparecem as Fendas Oraculares.
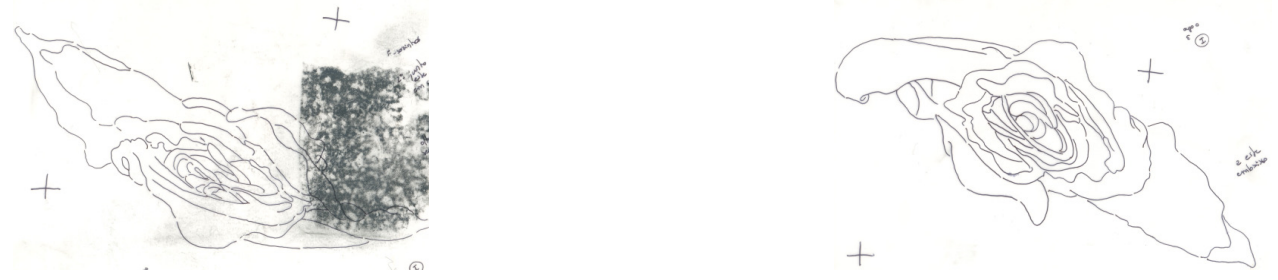

Desenhos preparatórios para as Fendas Oraculares

Parte dos novos desenhos foram ampliados e utilizados nas monotipias: miolos, dobraduras de pétalas, flores inteiras. Imagens que remetem ao mesmo tempo a formas vegetais, animais e ao desenho de panejamento.

Após algum tempo de elaboração e reelaboração desses novos trabalhos reconhecem-se nelas a identidade formal com as pinturas de flores de Georgia O'Keeffe. Percebe-se um parentesco direto ainda que técnicas diferentes sejam as utilizadas. No tratamento que sugere volumes por meio de luz e sombra, na evidente associação com o órgão genital feminino - outra das inúmeras simbologias da rosa - dada pela deformação e exagero das partes.

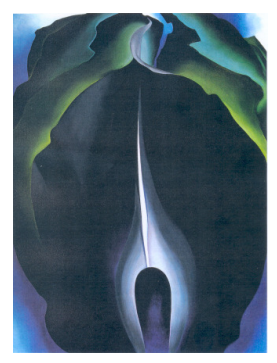

Georgia O'Keeffe,Jack-in-the-pulpit noIV, 1930.

Participou da elaboração da idéia das Fendas Oraculares uma seqüência associativa dos significados de fenda-flor-vagina-terra-oráculo de Delfos. Esta sequiência, percebida apenas no final da produção das obras, foi realizada de forma não completamente consciente e coincide com a história desse oráculo, ainda desconhecida no momento de criação. 
As conotações simbólicas do oráculo de Delfos serão desenvolvidas mais adiante, no capítulo Formula-te a ti mesmo, mas cumpre saber aqui que está implícito no modo de consulta em Delfos que a terra era considerada fonte primeira de revelação. Deméter (Gaia, em latim) era uma divindade ctônica também venerada no templo de Apolo ${ }^{105}$.

Antes de responder às perguntas dos consulentes, a Pítia descia para uma cavidade no templo onde tocava o omphalós. Cavidade, em grego, chama-se stómion, que também significa "vagina". Delphys, por sua vez, significa "útero" ${ }^{106}$. Evidencia-se a coincidência simbólica entre os significados associados ao templo de Delfos com a resolução formal das Fendas Oraculares.

Neste ponto de elaboração é possível identificar-se outro método heurístico de criação, o paradigmático ${ }^{107}$. Aqui reconhece-se que a criação de uma obra de arte procede de outras obras. Por esse método o artista constrói sua poética sem citações intencionais, mas incorporando as influências que sofreu ${ }^{108}$.

As Fendas Oraculares foram o primeiro tipo de oráculo imaginado. As palavras neles inscritas pronunciam a frase-chave do Conhece-te a ti mesmo: Homo sum ${ }^{109}$. O bordado,por meio do desenho e da cor, mimetiza-se nas curvas das rosas. Destina-se a ser procurado com cuidado pelo olhar.

\footnotetext{
105 Pierre LAVEDAN. Dictionnaire Illustré de la Mythologie et des Antiquités Grecques et Romanes.pp.710-713.

${ }^{106}$ Junito de Souza BRANDÃO. Dicionário Mítico-etimológico da Mitologia Grega. pp.94-95.

${ }^{107}$ Método semelhante ao da recodificação, diferencia-se deste último por construir o novo a partir de um universo amplo, recebido e percebido como influência. O método da recodificação, utilizado em outros momentos deste trabalho, por sua vez expressa uma nova situação partindo da intenção citatória de símbolos já existentes. Cf. Julio PLAZA e Mônica TAVARES. Op.Cit.pp.114-115.

${ }^{108}$ Ibidem.pp.114-115.

${ }^{109}$ Só está bordada a primeira e mais significativa parte da sentença de Terêncio: Homo sum; humani nihil a me alienum puto (Sou homem; nada do que é humano me é estranho).
} 


\section{Os Oráculos Portáteis}

São três. Os dois primeiros, construídos mediante um mesmo princípio que superpõe círculos concêntricos de rosas, manifestando-se invertido em cada peça, ao crescer e decrescer o diâmetro dos círculos, respectivamente ${ }^{110}$. Ambos trazem também a inscrição Homo sum alinhavada sobre tule dentro de suas cavidades. São elaborados para permanecerem sobre tripés ${ }^{111}$, à altura de um olhar que os possa observar de cima para baixo.

A marca distintiva das duas peças ${ }^{112}$ é o acúmulo de rosas que cria volume, tentando provocar uma sensação de solidez contraposta às partes ocas dos trabalhos. Compõem-se por monotipias-rosas encorpadas por várias camadas de tule costuradas nas peças.

Nesses primeiros Oráculos Portáteis, frutos do insight inicial desta série, a frase-chave encontra-se alinhavada numa única camada de tule fixada no fundo dos trabalhos. as palavras não estão completamente visíveis, é necessário mudar a direção do olhar, perscrutar as peças procurando a leitura e curvar-se sobre os oráculos, como se deles subisse a sentença procurada.

O terceiro Oráculo Portátil ${ }^{113}$ forma-se a partir das mesmas idéias essenciais: uma cavidade suspensa,construída em volta do espaço vazio e a necessidade de um olhar que investigue a obra de cima, por dentro e por fora.

Non legor, non legar ${ }^{114}$ : a sentença oracular não pertence à antigüidade. Embora possua um tom profético e misterioso se lido fora de seu contexto original, é

\footnotetext{
${ }^{110}$ Princípio já descrito detalhadamente nas páginas 91-92.

${ }^{111} \mathrm{O}$ tripé é uma explícita referência à trípode délfica, sobre a qual sentava-se a Pítia no momento do transe. Seus aspectos simbólicos serão tratados no capítulo Formula-te a ti mesmo.

${ }^{112}$ Ambas construídas com alinhavo sobre tule, monotipia sobre organdi recortado e costurado, 2005.

Dimensões sem os pedestais: 9 × 30 x $38 \mathrm{~cm}$. e 6 × 43 x $47 \mathrm{~cm}$.

${ }^{113}$ Non legor, non legar. Desenho com papel carbono dobre monotipia impressa sobre organdi recortado e costurado, 2005. Dimensões: 70 x 54 x $45 \mathrm{~cm}$.

${ }^{114}$ Não sou lido, não serei lido.
} 
uma frase de Nietzsche que se refere ao julgamento que o autor fazia da disposição e da capacidade de compreensão de seus contemporâneos sobre sua obra filosófica ${ }^{115}$.

O triunfo de Nietzsche torna-se o triunfo do oráculo. Enquanto oráculo e enquanto obra de arte, no sentido de que ambos oferecem-se à leitura e à interpretação dos consulentes-espectadores, mas nenhuma delas será completa e definitivamente legível. A plurivocidade é a característica de suas mensagens, oráculo e obra de arte, interpondo sempre, entre o objeto e seu espectador, um véu de inacessibilidade.

$\mathrm{Na}$ escolha das frases deste e de todos os outros oráculos atua o método heurístico da recodificação. Apresenta-se como uma criação de segundo grau, pois parte sempre de algo já codificado, elaborando signos da história como matéria-prima do processo criativo. Seus resultados reformulam criticamente uma situação e renovam-na, evidenciando outras conexões de sentido e inscrevendo os conceitos manipulados em outras categorias ${ }^{116}$. Nesse caso específico a recodificação assume o aspecto da transferência, que ocorre ao se transpor um signo de um meio para outro ${ }^{117}$.

O oráculo Non legor, non legar apresentava o desafio construtivo de ter os lados interno e externo desenvolvidos ao mesmo tempo, já que nasce apoiado sobre um aro circular e cresce para baixo, fechando-se o interior como se fosse uma forma destinada a conter algo e abrindo-se o exterior que o cobre, tal como uma vestimenta - uma saia que encobre a parte vital do trabalho.

Os procedimentos de monotipia e de costura utilizados já eram conhecidos e dominados, mas este oráculo novamente se diferencia pelo modo como nele se inscreve a sentença, desenhada sobre as monotipias-rosas já secas antes de serem incorporadas ao objeto tridimensional.

\footnotetext{
${ }^{115}$ Friedrich NIETZSCHE. Ecce homo.p.53.

${ }^{116}$ É um método de criação do novo e de compreensão do já criado, pois, segundo Wertheimer, exprimir fenômenos de um modo diferente ajuda a compreender suas implicações. Cf. Julio PLAZA e Mônica TAVARES. Op.Cit.p.115.

${ }^{117}$ Ibidem.p.115.
} 
O modo eleito para a transposição do desenho das letras e da renda sobre a tinta tipográfica foi o papel carbono branco para costura. Esse material aparenta-se tanto com os procedimentos de costura e com o repertório das costureiras e bordadeiras quanto com o universo da monotipia, com as propriedades de ter o gesto incisivo do desenho aplicado em seu verso, de impedir que se vejam seus efeitos sobre o suporte durante o desenho e de ser indireto: uma impressão. Foi escolhido por ser a melhor maneira de se desenhar linearmente e imprimir uma nova cor sobre a tinta tipográfica, que ao secar sobre o tecido torna-se altamente impermeável.

O oráculo gira no ar, mais por uma conseqüência de sua forma e do modo de montagem. Mesmo assim seu movimento remete aos sentidos de leitura horário e antihorário que se encontram na peça. Seu giro oferece ao leitor a sequiência das palavras de Nietzsche. 


\section{As Tautologias}

As três faixas baseiam-se na concretização do princípio da fita de Möbius ${ }^{118}$. A idéia de produzir este tipo de objeto provém da vontade de criar um trabalho que fosse manipulável pelo espectador e cuja forma conduzisse à leitura linear das frases ao mesmo tempo que proporcionasse um contato visual e tátil com a obra.

Todos os objetos construídos com as monotipias-rosas sempre despertaram em seus espectadores o desejo do toque. Essa vontade originava-se da curiosidade pelos procedimentos técnicos, natural frente a toda obra de arte, mas principalmente nascia da aparência de fragilidade dos trabalhos, feitos com tecido macio, brilhante, desenhado com figuras de flores e pela beleza dos objetos, que solicita primeiro os sentidos e só depois o intelecto.

Outro motivo para conceder esta série ao toque é a afinidade da poética com o corpo graças aos materiais usados, à presença do bordado e da costura como meio de construção e pelas dimensões das peças semelhantes às do corpo humano.

Por fim, a concessão ao toque do espectador relaciona-se de duas maneiras com a leitura. Na primeira é a possibilidade de se poder segurar o objeto que se lê, operação próxima da de tomar um livro nas mãos, que proporciona controle. Na segunda, por meio do acesso direto ao trabalho, mediante o toque, tenta-se assim contrabalançar o peso maior que a palavra costuma tomar frente à imagem.

Para suportar o manejo as Tautologias foram evidentemente construídas de forma mais resistente - as monotipias-rosas, por exemplo, desfiam-se com facilidade --

\footnotetext{
${ }^{118}$ A fita de Möbius é uma superfície de duas dimensões com apenas um lado, de faces aparentemente antagônicas, mas apresentando-se como uma única face com uma única borda, isto é, uma superfície contínua. É obtida unindo-se as duas extremidades de uma fita após dar-se meia-volta numa delas. Conceito criado em 1858 por August Ferdinand Möbius (1790-1868) que está relacionado ao ramo da topologia da matemática. Cf. // inorgan 221.iq.unesp.br/quimgeral//moebius/moebius.htm/. Acesso em: agosto 2005 .
} 
mas sem perder a fragilidade que lhes é inerente, tanto na aparência quanto no toque. $\mathrm{O}$ que condiciona a aproximação física do espectador, que deve ser necessariamente tão delicada quanto as peças. O manuseio das fitas sugere lentidão e cuidado tanto quanto a investigação visual que procura a leitura das sentenças.

A primeira Tautologia elaborada ${ }^{119}$ apresenta uma sentença modificada de um verso de um poeta moderno brasileiro, Cassiano Ricardo: Os culpados é que fazem os inocentes; os inocentes é que fazem os culpados ${ }^{120}$.

Não é um mote clássico, nem foi escrito originalmente em latim ou grego, mas decididamente tem o caráter misterioso de uma emissão oracular. A inversão dos sujeitos do verso adapta-se perfeitamente à repetição dada pelo contínuo girar da fita.

Outra particularidade que diferencia esta Tautologia de todos os trabalhos pertencentes ao Conhece-te a ti mesmo é a ausência de monotipias-rosas. A peça foi elaborada com renda branca e preta e voile preto.

Esse objeto é um raro fruto de uma abordagem totalmente experimental de uma nova idéia - era preciso experimentar se a construção como obra da fita de Möbius era viável - que ganha autonomia não só como obra e conquista um lugar significativo dentro de uma série.

É a menor das fitas. Suas dimensões concentram-se apenas no envolvimento das mãos de quem a manipula. Oferece-se suspensa ao espectador, assim como as outras duas fitas, retirável de seu suporte para o manuseio.

\footnotetext{
${ }^{119}$ Bordado sobre renda e voile, 2004. Dimensões: 11 x 26 x $26 \mathrm{~cm}$.

${ }^{120}$ O verso original é: "Os culpados é que fazem os inocentes", do poema A Rosa das Três Graças (Poderia Ter Sido Eu), publicado no livro Poemas Murais, de 1950. (São José dos Campos, 1895- Rio de Janeiro, 1974). Cf. Cassiano RICARDO. Poesias Completas.p.523.
} 
A segunda Tautologia ${ }^{121}$ traz alternadamente bordadas a frase de Píndaro Génoi hoios essi ${ }^{122}$ e sua tradução em português, em posição de leitura invertida uma em relação à outra, causando assim a inversão do sentido da movimentação da fita pelo espectador para que possa ler ambas as frases. Os materiais utilizados e os procedimentos de construção da fita são os usuais desta poética.

É mais longa do que a anterior. Ao movimentá-la, os braços têm seus movimentos ampliados, a fita já consegue se acomodar ao corpo do espectador se este o desejar, mas ainda não o envolve. Essa peça é ainda explicitamente uma fita de Möbius, idéia intermediária entre as três fitas, mas onde evolui um desejo de integração corporal entre objeto e espectador.

A terceira Tautologia ${ }^{123}$ conserva o conceito de construção de uma fita de Möbius, contudo, a sua aparência escapa a um reconhecimento imediato daquela forma.

O oráculo Ne quid nimis ${ }^{124}$ foi planejado para que fosse vestido, para que seu manuseio como fita não fosse uma operação nem clara nem fácil, mas que apesar disso envolvesse fisicamente o espectador, podendo a peça ser penetrada pela cabeça ou pelos braços nas duas fendas que apresenta.

O objeto só é reconhecível como fita de Möbius ao se perceber que a dobra que apresenta não se desfaz. Ao se virá-lo várias vezes pelo seu avesso, tentando desdobrálo numa operação inicialmente confusa, é que se compreende seu movimento natural.

\footnotetext{
${ }^{121}$ Bordado sobre monotipia impressa sobre organdi recortado e costurado, 2006. Dimensões: 11 x 77 x $77 \mathrm{~cm}$.

122 "Torna-te aquilo que és". Frase de Píndaro, poeta grego (518 A.C., Tebas - 438 A.C.,Argos) utilizada como máxima por Nietzsche desde a juventude. Subtítulo do livro Ecce homo, também aparece em outros escritos do filósofo, ponto importante numa de suas principais questões, a superação de si mesmo. Cf. Paulo César de SOUZA. Posfácio. p.135.

${ }^{123}$ Bordado sobre monotipia impressa sobre organdi recortado e costurado, 2006. Dimensões: 92 x 67 x $67 \mathrm{~cm}$.

124 "Nada em demasia". Uma das admoestações inscritas no templo de Apolo em Delfos, ou, segundo uma tradução de Panofsky: "Que nunca se faça demais".Cf. Erwin PANOFSKY. Significado nas Artes Visuais.p.391.
} 
Ne quid nimis é o único trabalho que incorpora a cor: o vermelho forte borda as palavras gregas repetidas muitas vezes por toda a superfície da peça, que podem ser lidas ora na ordem correta, ora fora dela, caoticamente. Esse trabalho não guia mais linearmente a leitura, pois envolve, veste seu espectador.

Toda a superfície do oráculo é recoberta por monotipias. Reúnem-se nele muitas imagens de flores pertencentes a vários períodos de produção, datando algumas de 1999, do início da pesquisa deste tipo de poética, com as várias soluções gráficas dadas pelo tempo.

Usou-se aqui o método heurístico dos limites em vários níveis. Primeiro em relação ao limite possível da relação entre altura e largura da fita de Möbius que ainda permitisse sua manipulação. Também foram desafiados os limites de construção de uma peça - nesse caso mais complexa -- e dos procedimentos técnicos usados, principalmente o único rigorosamente intocado até o momento: a exclusividade do preto.

Nada em demasia, nos avisa Apolo, deus da justa medida. Eis o outro sentido segundo o qual testa-se neste trabalho a expansão até o excesso dos limites autoimpostos por um planejamento, pelo hábito, por uma forma eleita e pela quantidade de elementos reunida numa só peça. Não foi por coincidência que tenha sido este o trabalho que encerra o ciclo do Conhece-te a ti mesmo. 


\section{As palavras e as imagens}

Os oráculos trazem em si palavras. As sentenças formam uma cadeia que começa fora da obra, com o título geral do conjunto - Conhece-te a ti mesmo --, prosseguem na titulação das séries - Fendas Oraculares, Oráculos Portáteis e Tautologias - e culminam com as frases inscritas em cada objeto - Homo sum; Non legor, non legar; Os culpados é que fazem os inocentes, os inocentes é que fazem os culpados; Génoi hoios essí e Ne quid nimis.

Após uma aparição inicialmente tímida da palavra nesta poética, na qual só haveria uma titulação geral e uma única resposta concedida pelo oráculo - Homo sum a palavra irrompeu e proliferou-se. Trouxe consigo significações já construídas histórica e culturalmente. Porém, ao alojar-se num novo organismo, dá e recebe novos sentidos.

Diante de qualquer um dos oráculos o primeiro contato dá-se pelo olhar. Ele estabelece uma estratégia própria de investigação, cria seu próprio percurso para reconhecer o trabalho observado como um todo, como um "sistema fechado de visibilidade" ${ }^{125}$.

Reconhece-se uma palavra. Entra em jogo nesse momento um novo elemento a ser decifrado. Diferente da imagem, mas também a seu modo imagem, é reconhecível como parte de um outro código não apenas visual e portador de muitas normas.

Todavia, palavra e imagem estão juntas na obra. A investigação do trabalho pelo espectador esforça-se por torná-lo um "texto legível" ${ }^{126}$. O olhar, o intelecto e a

\footnotetext{
${ }^{125}$ As três operações de contemplação descritas neste e nos próximos três parágrafos são as modalidades elaboradas por Marin a propósito da análise da pintura de Poussin $O$ Maná. Embora esta obra não apresente palavras escritas, o autor a analisa conforme conceitos de visibilidade e legibilidade, cabíveis tanto para as obras nas quais Poussin utiliza a palavra escrita quanto para o Conhece-te a ti mesmo.Cf. Louis MARIN. Sublime Poussin.p.27.

${ }^{126}$ Louis MARIN.Ibidem.p.27.
} 
sensibilidade reconhecem seus elementos e tentam construir um ou vários sentidos que unifiquem as percepções.

A contemplação ${ }^{127}$ torna-se "repetição diversificada dos percursos de visão e dos percursos de leitura" ${ }^{128}$, na qual se conjugam harmoniosamente visibilidade e legibilidade. Atinge-se um olhar ao mesmo tempo contemplador e leitor das imagens e das palavras.

O parentesco entre as letras, a palavra e o texto com a imagem e o desenho é algo visível não apenas no contexto artístico, mas até no território da palavra, onde só o logos predomina.

As palavras possuem sua própria aparência. Encantam, perturbam, como no caso dos alfabetos desconhecidos ${ }^{129}$. Numa tal situação, mesmo sem compreensão intelectual, atua um olhar que observa as formas. De modo diferente do que seria na leitura, olha-se para a letra como desenho e esta impõe-se como figuralidade ${ }^{130}$. A estranheza de sua aparência provoca um distanciamento, cujo efeito é o de prolongar a duração da investigação visual ${ }^{131}$.

Marin amplia a abrangência dessa constatação e vê na própria página escrita, manuscrita ou impressa, ao mesmo tempo, tanto o seu aspecto de leitura linear quanto o de ser quadro e visão:

"O legível e o visível têm fronteiras e lugares comuns, superposições parciais e imbricações incertas" 132 .

\footnotetext{
${ }^{127}$ Termo usado por Marin, essa palavra torna-se adequada a este caso de recepção se lembradas as categorias de obras abertas à recepção elaboradas por Plaza. Esta poética seria provavelmente definida por este último autor como uma imagem de primeira geração, devido ao seu processo produtivo ser artesanal. O Conhece-te a ti mesmo, porém, permite dois tipos de participação por parte do espectador: passiva (que envolve principalmente a contemplação, entre outras ações) e a ativa (que embora solicite a manipulação e a exploração da obra, neste caso ainda privilegia o olhar, a contemplação). Cf. Julio PLAZA. Arte e Interatividade: autor-obra-recepção. Revista Ars, $n^{\circ} 2$.p.10.

${ }^{128}$ Louis MARIN. Op.Cit. p.27.

${ }^{129}$ Wilcon Joia PEREIRA. Escritema e Figuralidade nas Artes Plásticas Contemporâneas.pp.46-47.

${ }^{130}$ Wilcon Joia PEREIRA. Ibidem.p.49.

${ }^{131}$ Wilcon Joia PEREIRA. Ibidem.pp.46-47.

${ }^{132}$ Louis MARIN. Op.Cit.p.19.
} 
Sartre fortalece a ligação entre palavra e imagem individuando o tipo de percepção visual e intelectual que nos solicita a visão da palavra e do texto:

"(...) a palavra desempenha muitas vezes o papel de representante sem abandonar o de signo, e estamos lidando, na leitura, com uma consciência híbrida, meio significante e meio imaginante" ${ }^{133}$.

$\mathrm{Na}$ arte a relação entre palavra e imagem sempre foi estreita. Historicamente criou-se no ocidente desde a baixa antigüidade até o século XVIII uma tradição de pintura e interpretação de um quadro baseadas na leitura de imagens, dado o forte vínculo que havia entre um texto pré-existente ao quadro, a leitura realizada pelo artista antes de elaborá-lo e o que o espectador deveria procurar e ler do texto original nas figuras do quadro finalizado ${ }^{134}$.

A tradição modificou-se na arte contemporânea, mas permaneceu a atração pela palavra. Ao discorrer sobre essa presença no trabalho de Mira Schendel, Dias diferencia em duas as possibilidades da manifestação da palavra num trabalho artístico. Uma delas seria usando-as "enquanto elementos formais complementares".

A segunda forma seria aquela realizada por alguns artistas conscientes da impossibilidade de separar-se o puramente visual do contexto verbal. Estes procurariam encontrar na relação da escrita com a imagem "novas formas para este vínculo arcaico entre o homem e o mundo" ${ }^{135}$.

\footnotetext{
${ }^{133}$ Jean-Paul SARTRE. O Imaginário.p.96.

${ }^{134}$ Luis MARIN. Op.Cit.p.21. Por exemplo, na arte religiosa. Nela, a palavra guia a interpretação da imagem. Cf. Ibidem.p.24.

${ }^{135}$ Geraldo de Souza DIAS FILHO. Contundência e Delicadeza na Obra de Mira Schendel.Revista Ars, $n^{\circ}$ 1.p.123.
} 


\section{A palavra desenhada}

O primeiro instrumento da escrita foi a mão. Forma-se um laço entre mão e olho neste processo: a primeira instruindo o segundo e este corrigindo-a, numa alternância contínua desde seu surgimento ${ }^{136}$.

Vários fatores influenciaram e influenciam a evolução do desenho das letras: linguagem, literatura, educação, política, organização do estado, os interesses de grupos sociais pela maior ou menos legibilidade da escrita, arquitetura, arte, as ferramentas da escrita $^{137}$.

O desenvolvimento de mais elaborados e eficientes instrumentos e, portanto, maior rapidez de registro, correspondeu a uma necessidade prática das sociedades que cada vez mais utilizavam-se da escrita como registro de atividades econômicas, de propriedades, ordem e administração política ${ }^{138}$.

Para além do pragmatismo, a religião foi um fator relevante para o desenvolvimento da escrita e de seu desenho. Através dos séculos houve povos que atribuíram a invenção da escrita a deuses ${ }^{139}$, o que encontra identificação com a percepção de Barthes de que a letra está ligada às mais profundas experiências da humanidade ${ }^{140}$.

Ocorre uma mudança importante na escrita no tempo de Solon ${ }^{141}$. Até aquele momento a escrita dirigia-se da direita para a esquerda, movimento mais natural para a maioria destra. Solon edita leis invertendo o sentido da escrita, alternando-se uma linha escrita da direita para a esquerda com outra da esquerda para a direita, o chamado estilo

\footnotetext{
${ }^{136}$ Albert KAPR. The Art of Lettering. p.12.

137 Ibidem.pp.20-21.

138 Ibidem.p. 20.

${ }^{139}$ Para os egípcios Toth era o deus da escrita. Para os budistas, Brahma a havia inventado. Cf. Ibidem.p.14.

${ }^{140}$ Roland BARTHES. O Óbvio e o Obtuso.p.107.

${ }^{141}$ Legislador ateniense, 640 A.C.-560 A.C.
} 
boustrophedon ${ }^{142}$. Adotou-se depois apenas uma única direção, da esquerda para a direita, pois a inversão do gesto e das letras ao se escrever em duas direções mudava a aparência dos caracteres ${ }^{143}$.

O templo de Apolo em Delfos, com a sentença gnothi së auton ${ }^{144}$ inscrita em seu pórtico da esquerda para a direita coincide com o surgimento e início de uso dessa única e nova direção de escrita ${ }^{145}$.

O interesse desta pesquisa limita-se ao estilo cursivo de escrita e suas imbricações com o desenho. Sua relevância estética evidencia-se com o passar dos séculos.

O cursivo apresenta duas características da letra manuscrita, que são as de ligar as letras entre si e usar a minúscula. Esse estilo tem origem na vida prática e na econômica, resultado de uma necessidade simplificadora, e de uma tendência a se escrever mais depressa, sem preocupações estéticas ${ }^{146}$.

Ele traz a marca da passagem rápida de uma idéia a outra, de um signo a outro. É associado à fala coloquial e espontânea. Este tipo de escrita acabou por produzir novas formas de escrever, posteriormente selecionadas e refinadas pela caligrafia, num processo de influência mútua entre a letra impressa (ou cinzelada em épocas anteriores) e a manuscrita ${ }^{147}$.

\footnotetext{
${ }^{142}$ Que significa "como os bois, de um sulco para o outro". Cf. Albert KAPR Op.Cit. p.16.

${ }^{143}$ Albert KAPR. Op.Cit. p.16.

144 "Conhece-te a ti mesmo".

${ }^{145} \mathrm{O}$ aparecimento desta direção de escrita " representa para Gebser um momento importante na evolução da humanidade. Somente então seria possível falar-se em História, com o surgimento de um princípio masculino determinado pelo gesto de endireitar, legislar, direcionar". Cf. Geraldo de Souza DIAS FILHO. Op.Cit.p.124. Corroborando o sentido da citação lembremo-nos da atribuição da sentença do templo a Sócrates e o valor dado pelo filósofo ao conhecimento e ao equilíbrio atingido pela faculdade racional do logos.

${ }_{146}$ Albert KAPR.Op.Cit. p.16.

${ }^{147}$ Ibidem.p.16.
} 
A prática da caligrafia evidenciava as semelhanças entre o traço desenhado e o traço escrito dando importância à mão que produzia o trajeto ${ }^{148}$, atividade valorizada nos séculos XVI a XVIII tanto nas letras impressas quanto nas manuscritas ${ }^{149}$.

As letras utilizadas no Conhece-te a ti mesmo foram criadas por Pierre Didot em 1798 , simulando o aspecto de manuscritas ${ }^{150}$.

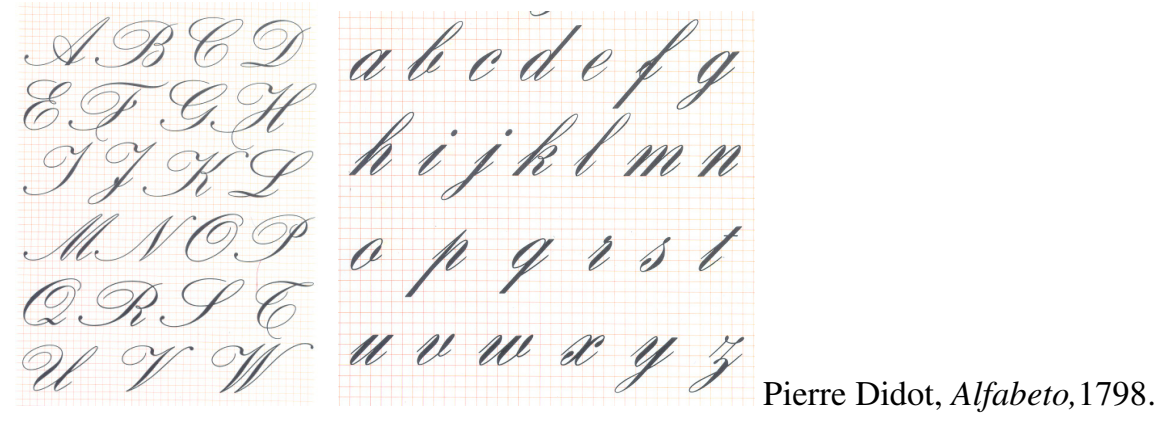

Em alguns oráculos a letra não segue rigorosamente o desenho de Didot, mas propositalmente assume um trajeto que segue os contornos das rosas - como nas Fendas Oraculares - ou que imita um modo de escrever menos refinado mas ainda aparentando um esforço no esmero da caligrafia, como nos manuais de bordado - nos dois primeiros Oráculos Portáteis.

A idéia em simular uma letra de manual proveio da caligrafia dos quadros de Magritte. Esta é, portanto, uma referência anterior e conscientemente escolhida no Conhece-te a ti mesmo: um método de recodificação.

$\mathrm{O}$ artista escreve e desenha sutilmente suas letras. Em sua obra criam-se paradoxos na relação entre as figuras com a escrita, mas aqui o principal interesse é o incômodo que nasce da junção da primariedade simulada de afirmações verbais claras inocentes à primeira vista com o que as palavras afirmam enquanto desenho de letras 151. Um desenho que sugere um traçado cuidadoso, que revela um esforço de domínio de

\footnotetext{
${ }^{148}$ Roland BARTHES. O Óbvio e o Obtuso.p. 141.

${ }^{149}$ Ibidem.p. 139.

${ }^{150}$ Roger DRUET e Herman GREGOIRE. La Civilisation de L'Ecriture.pp.190-191.

${ }^{151}$ Como afirma Sartre, as palavras, suas formas e seu desenho são primeiro percebidas visualmente. Essa percepção adiciona-se ao significado da palavra e inclusive ao seu som. Cf. Jean-Paul SARTRE. Op.Cit. p.96.
} 
um código ${ }^{152}$ como se o artista fizesse o possível para que seu espectador acredite na coerência do paradoxo.

Segundo Barthes, enquanto for legível, a escritura é instrumento ${ }^{153}$. Este é o uso que se faz da palavra no Conhece-te a ti mesmo. Embora exista uma preocupação formal com a letra - pois seu desenho também constitui um nível de leitura ${ }^{154}$-- o foco da criação artística está na palavra como unidade significativa ${ }^{155}$.

A questão central na relação com a palavra que se revela neste trabalho é o seu uso na forma de sentenças. Nos títulos e nas peças, lêem-se frases escolhidas em outros contextos.

Na história da arte repetidamente foram usados motes clássicos, provérbios, frases bíblicas de admoestação moral inscritas em pinturas, gravuras, monumentos. Especificamente as Tautologias encontram um parentesco dentro dessa tradição com um certo tipo de imagem que traz sentenças de cunho moral ou religioso sobrepostas à figuração na forma de faixas.

Essa associação surgiu após a elaboração das fitas de Möbius, não tendo sido, desse modo, um ponto de partida para o trabalho, como no caso da caligrafia magritteana, mas uma relação pensada em retrospectiva que colabora com novos sentidos para o trabalho.

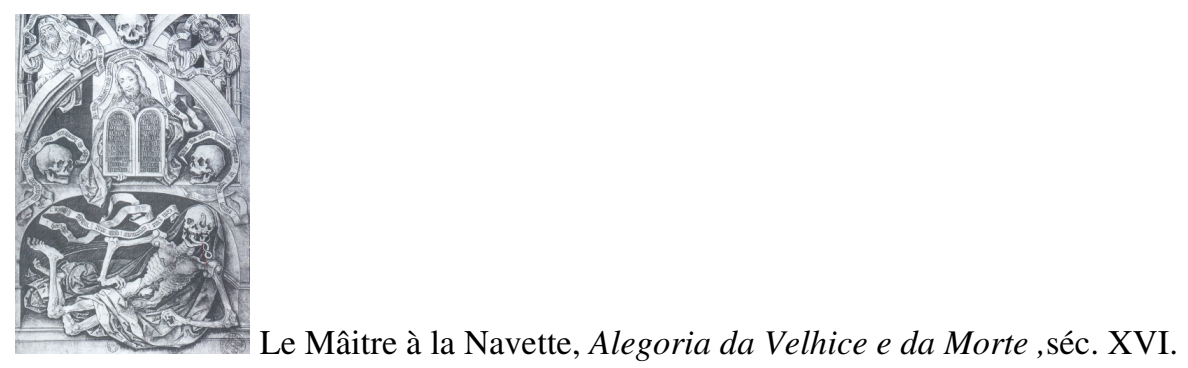

\footnotetext{
${ }^{152}$ Roland BARTHES. Op.Cit. p.144.

${ }^{153}$ Ibidem.p.141.

${ }^{154}$ Michel BUTOR. Op.Cit. p.102.

${ }^{155}$ Roland BARTHES. Op.Cit. p.107.
} 
No exemplo acima as sentenças mostram-se suspensas e apostas à imagem. Seu significado aproxima-se da idéia de título e sua disposição claramente guia a leitura. São escritas sobre faixas, têm um caráter sonoro que traz aos lábios do observador a sentença que se desenvolve em diferentes partes da imagem ${ }^{156}$.

Butor encontra a origem desse tipo de representação nos filactérios ${ }^{157}$, o que coincide formalmente com as Tautologias, na idéia de uma leitura conduzida pelas mãos, no tom admoestatório e na decifração das frases que pode pronunciar a sentença lida lentamente.

Em todos os trabalhos do Conhece-te a ti mesmo a inscrição das sentenças é apenas um dos elementos propostos. $\mathrm{O}$ conjunto proposto forma-se do objeto, da inscrição e do título. A titulação pode indicar o que se deve procurar na obra, como se traduz a inscrição grega ou latina ou até mesmo, por meio dos títulos das séries, abrir algumas vias de interpretação.

O uso num trabalho artístico de sentenças da antigüidade clássica ou colhidas de outros contextos poéticos ou filosóficos tem precedentes importantes na arte. Escritos antigos ou consagrados são elementos que carregam consigo seu próprio peso, a ponto de poderem debilitar a imagem com sua força.

O exemplo por excelência para guiar essa discussão e apontar leituras que concedam importâncias equivalentes à palavra e à imagem são as análises feitas primeiro por Panofsky, seguido por Marin, o qual debruça-se em parte sobre a obra e sobre o texto do estudioso, acerca do quadro Os Pastores da Arcádia, de Poussin ${ }^{158}$.

\footnotetext{
${ }^{156}$ Michel BUTOR. Op.Cit. p.102.

${ }^{157}$ Filactério é uma faixa de pergaminho com as extremidades enroladas sobre a qual estão escritas passagens da Bíblia, como por exemplo os preceitos do decálogo. De pequenas dimensões são originalmente carregadas em invólucros na testa ou no braço esquerdo por judeus para que se lembrem da palavra de Deus. Cf. Antônio HOUAISS. DicionárioHouaiss da Língua Portuguesa.p.1340.

${ }^{158}$ Nicolas Poussin ( Les Andelys, 1594 - Roma, 1665).
} 


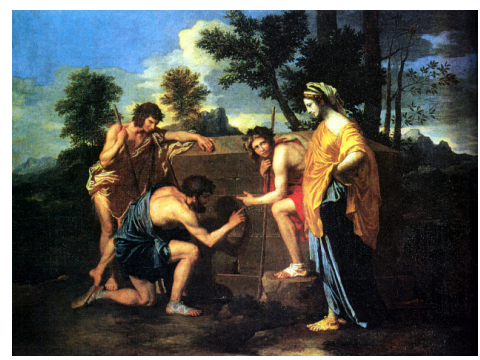

Nicolas Poussin, Os Pastores da Arcádia,1638-9.

Vê-se na tela, num primeiro olhar, uma construção quadrangular que parece despertar em muito o interesse de quatro personagens, "simetricamente dispostos nos dois lados de um monumento sepulcral" ${ }^{159}$.

A atenção de todos concentra-se em direção a uma das faces "numa discussão calma e contemplação meditativa" ${ }^{160}$, estando aquela apenas parcialmente encoberta pelos personagens, cuja atitude deixa um espaço de visão ao espectador bastante significativo, o que lhe permite, inclusive, perceber e ler uma inscrição cinzelada na pedra. O espaço aberto aproxima o espectador do grupo, incluindo-o na discussão ${ }^{161}$.

Os personagens permanecem silenciosos, ou pensativos, ou investigam a pedra com o tato, ou discutem. Há uma escrita sendo decifrada:

"Um dos pastores ajoelha-se no chão, como se estivesse relendo a inscrição para si mesmo. O segundo parece discutir o texto com uma bela jovem que medita sobre ele numa atitude pensativa, calma. O terceiro parece imerso em melancolia." ${ }^{162}$.

Essa foi a segunda versão de Poussin sobre um tema clássico da pintura, o memento mori, anteriormente elaborado também por outros pintores a partir da frase em latim Et in Arcadia ego ${ }^{163}$.

\footnotetext{
${ }^{159}$ Erwin PANOFSKY. O Significado nas Artes Visuais.

${ }^{160}$ Ibidem.p. 401.

${ }^{161}$ Michel BUTOR. Op. Cit. p.130.

${ }^{162}$ Erwin PANOFSKY. Op.Cit. p.401.

${ }^{163}$ A análise sobre o sentido da frase é o assunto do texto, mas pode ser traduzida como "Mesmo na Arcádia, também estou" se entendida como memento mori ou "Eu, também, vivi na Arcádia" se entendida sob o significada dado por Poussin. Cf. Erwin PANOFSKY. Et in Arcadia Ego: Poussin e a Tradição Elegíaca. pp.377-409. As traduções da frase localizam-se nas páginas 400 e 404, respectivamente.
} 
Eis a descrição da obra feita por Panofsky. Note-se que nela o estudioso já aponta as diferenças de sentido na interpretação da frase que a segunda versão da pintura causa:

"Aqui, portanto, temos uma mudança básica de interpretação. Os árcades não parecem tanto estar sendo advertidos sobre um futuro implacável quanto estar imersos numa doce meditação acerca da beleza do passado.. (...) o quadro de Poussin que está no Louvre não mostra mais um encontro dramático com a Morte e sim uma absorção contemplativa na idéia da imortalidade. Confrontamo-nos com a mudança de um moralismo finamente velado para um sentimento elegíaco evidente." ${ }^{164}$.

Após uma análise da frase latina, cujo significado gramatical correto não coincidiria com as imagens de Poussin, o autor conclui que a mudança na interpretação da frase não se deu por ignorância, mas pelas próprias mudanças que ocorrem nos modos de pensar de cada época e lugar e, principalmente, graças às intenções do artista 165

A leitura da antiga frase latina com um sentido único reiterado durante séculos renovou-se na obra de arte por meio da vinculação interna estabelecida entre a sentença e as imagens. Embora ler signifique reconhecer signos e estruturas, a compreensão implica também no "decifrar, interpretar, visar e, talvez, adivinhar o sentido de um discurso" ${ }^{166}$.

A conclusão sugerida por ambos os estudiosos é de que uma obra de arte, em última instância, sempre se refere a si própria, tece seu próprio e novo discurso, mesmo que incorpore elementos estranhos a seu universo e mesmo que esses elementos pertençam a um território verbal altamente sedimentado na cultura ${ }^{167}$.

Eis então o sentido proposto para a aproximação das sentenças oraculares do Conhece-te a ti mesmo.Não se deve pender apenas para a contemplação da pura aparência nem somente para a operação intelectual de leitura linear das frases. Deve-se

\footnotetext{
${ }^{164}$ Ibidem. p. 401.

${ }^{165}$ Ibidem. pp. 401-409.

${ }^{166}$ Louis MARIN. Op.Cit. p.20.

${ }^{167}$ Ibidem.p. 119.
} 
operar no desvio que se forma entre o visível e o legível, no qual ocorre, sim, uma polarização, mas da mesma forma uma troca ${ }^{168}$.

${ }^{168}$ Ibidem. p. 37. 


\section{Influências e afinidades formais com trabalhos de outros artistas}

"Criar é produzir um objeto que não vem evidentemente do nada,mas que, apesar de tudo, é novo" 169

As influências sofridas podem aparentemente contrapor-se à idéia de originalidade, associando-se possivelmente a uma concepção depreciativa de imitação. Segundo o conceito de exemplaridade de Pareyson, nenhum dos termos anteriores desfigura o valor e a autonomia de um trabalho, compondo na verdade a continuidade que faz uma obra ligar-se a outra por filiação ${ }^{170}$.

A originalidade de uma obra nunca é um começo absoluto. Uma obra é lentamente construída filiando-se a uma situação que a precede e aparenta-se a um contexto artístico no qual se desenvolve ${ }^{171}$.

O conceito de originalidade de uma obra inclui as que a precederam, delas alimenta-se e deriva, dando dessa forma continuidade ao caráter exemplar que a obra de referência assume, porque bem-sucedida. O sentido de imitação, nesse caso, é a orientação, a solução de problemas que uma obra bem-sucedida representa para as que a seguem ${ }^{172}$.

Dentro da pequena parcela de influências claramente detectáveis em seu próprio trabalho por quem cria são agora discutidas as mais fortes formas de congenialidade ${ }^{173}$ percebidas com outras obras na formação da e na poética do Conhece-te a ti mesmo.

\footnotetext{
${ }^{169}$ Mikel DUFRENNE. A Estética e as Ciências da Arte. p.16.

${ }^{170}$ Luigi PAREYSON. Estética. Teoria da Formatividade.p. 134.

${ }^{171}$ Luigi PAREYSON. Os Problemas da Estética.p.136.

${ }^{172}$ Luigi PAREYSON. Estética. Teoria da Formatividade.pp.133-137.

${ }^{173}$ Segundo Pareyson a congenialidade é uma semelhança entre duas ou mais obras. É o elemento que solicita a influência de obras pré-existentes ao propor situações afins, exigências semelhantes, problemas próximos. Cf. Luigi PAREYSON. Ibidem.pp.136-138.
} 
No período de formação acadêmica foi decisiva a atuação como professora e o contato com a obra de Carmela Gross. A intensidade com que durante as aulas praticouse e valorizou-se o desenho de observação, a reflexão sobre os resultados e o processo, contribuíram fortemente para construir uma idéia de desenho que permeia a elaboração de um trabalho desde seu início: planeja-o, testa-o, participa de sua concepção espacial.

A presença da influência artística de Gross evidencia-se também na identidade formal com várias peças, visivelmente em dois oráculos do Conhece-te a ti mesmo.

A semelhança deu-se não como fenômeno conscientemente programado e autoimposto, mas, segundo a congenialidade descrita por Pareyson, por uma situação espacial imaginada para os oráculos análoga aos trabalhos de Gross, isto é, de construção de uma estrutura tridimensional mediante o recorte que desenha uma forma e a contínua sobreposição de recortes bidimensionais que se assemelham pela forma até atingir-se um volume.
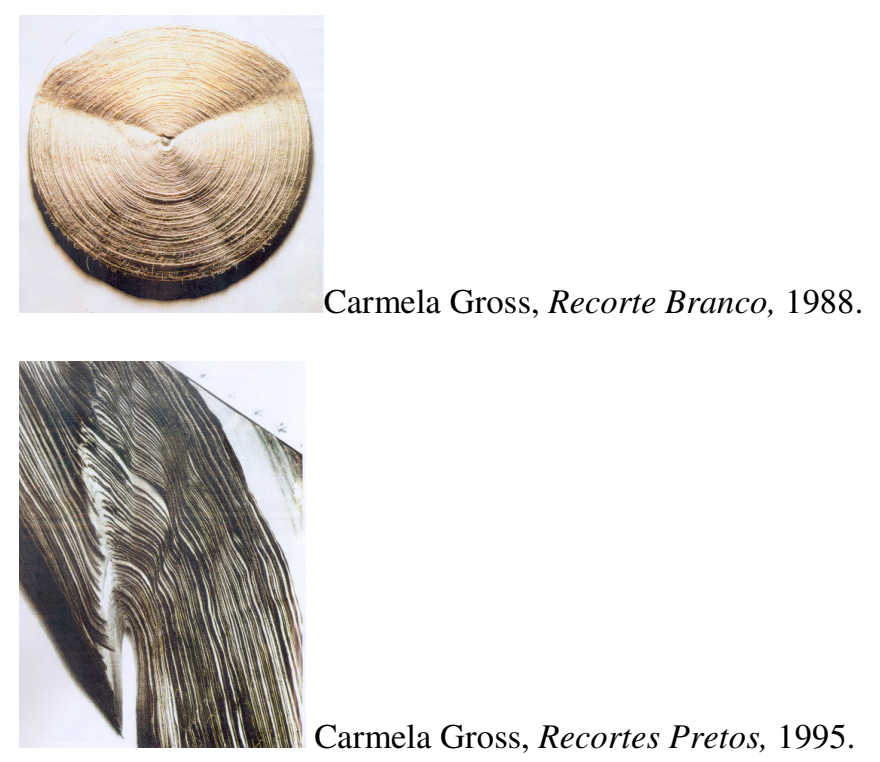

Uma outra maneira de formação artística é a que ocorre mediante o impacto causado pelo contato direto e sem palavras com outras obras de arte. Esse efeito profundo pode revelar-se depois de anos, quando características ressurgidas daquelas obras admiradas voltam a se manifestar em novos trabalhos como influências cujas afinidades só se evidenciam após um olhar retrospectivo. 
Seguiu por esse caminho a incorporação de alguns aspectos de semelhança formal, de procedimentos, de atenção despertada pelo material usado e de qualidades percebidas nas obras de dois artistas vistas em duas exposições: Leonílson e Mira Schendel ${ }^{174}$.
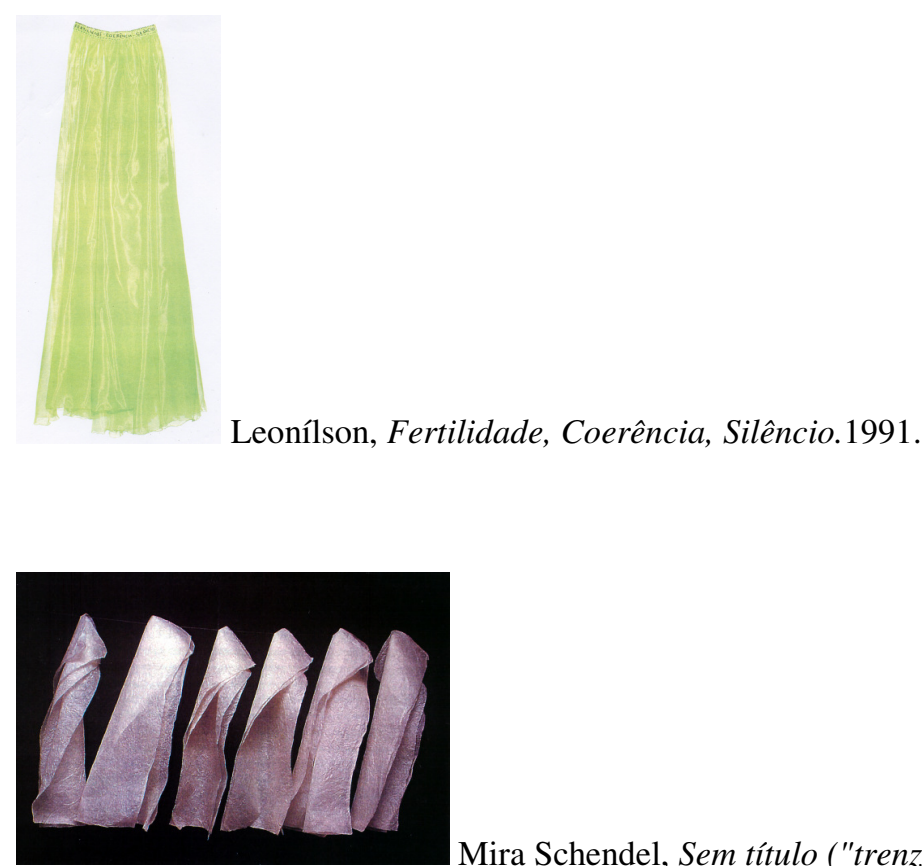

Mira Schendel, Sem título ("trenzinho"), déc. de 60.

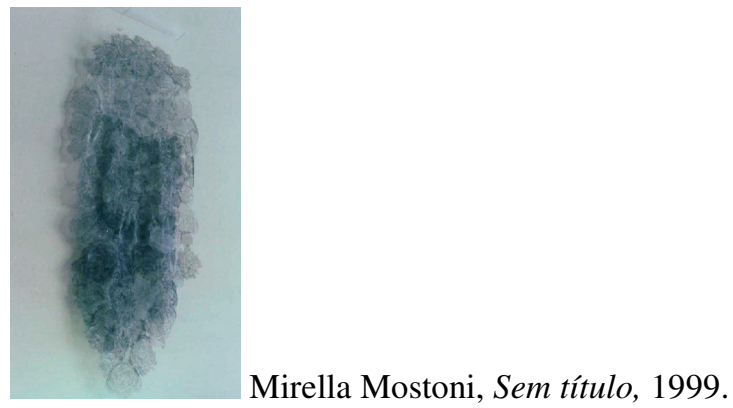

A influência de Leonílson é perceptível nesta poética primeiro pelas escolhas de material e procedimentos que repetem algumas das feitas pelo artista: o tecido leve, sintético e transparente; a renda; a aparência de vestimenta que tomam algumas peças; a

\footnotetext{
${ }^{174}$ Ambas as retrospectivas na Galeria do SESI, São Paulo. São Tantas as Verdades, de Leonílson (19956) e No Vazio do Mundo, de Mira Schendel (1996-7).
} 
costura amadora que as constrói; a escritura bordada, se bem que, neste último aspecto,com menos semelhanças de conteúdo e forma.

A proximidade com Schendel revela-se não tanto no uso que a artista faz da monotipia, embora o princípio de impressão usado seja o mesmo, mas especialmente na delicadeza aparente que seus trabalhos assumem, na leveza dos suportes transparentes.

Ao pensar nos procedimentos que se sobrepõem na poética do Conhece-te a $t i$ mesmo: desenhar, recortar, acrescentar, bordar, vê-se sua repetição nos trabalhos de muitos artistas brasileiros contemporâneos. Em especial, a naturalidade com que Leda Catunda apropriou-se e utilizou-se desses procedimentos desde os anos 80 foi o precedente que permitiu a mesma naturalidade de uso nesta poética a partir de 1997.

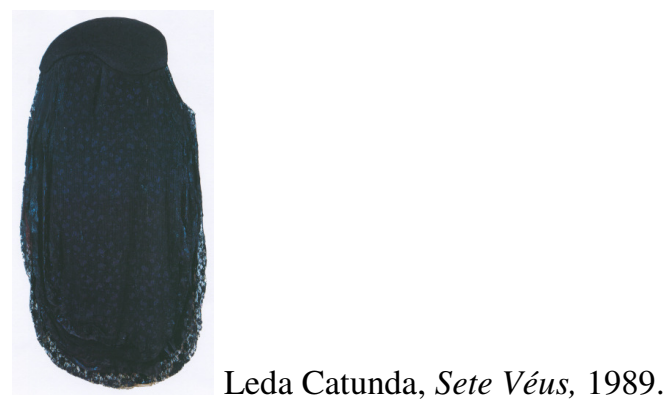

Outra referência encontrada é a beleza dos materiais usados por Waleska Soares. As rosas, a atração tátil que os materiais usados em seus trabalhos despertam, já belos por si só nos caimentos, nas texturas.

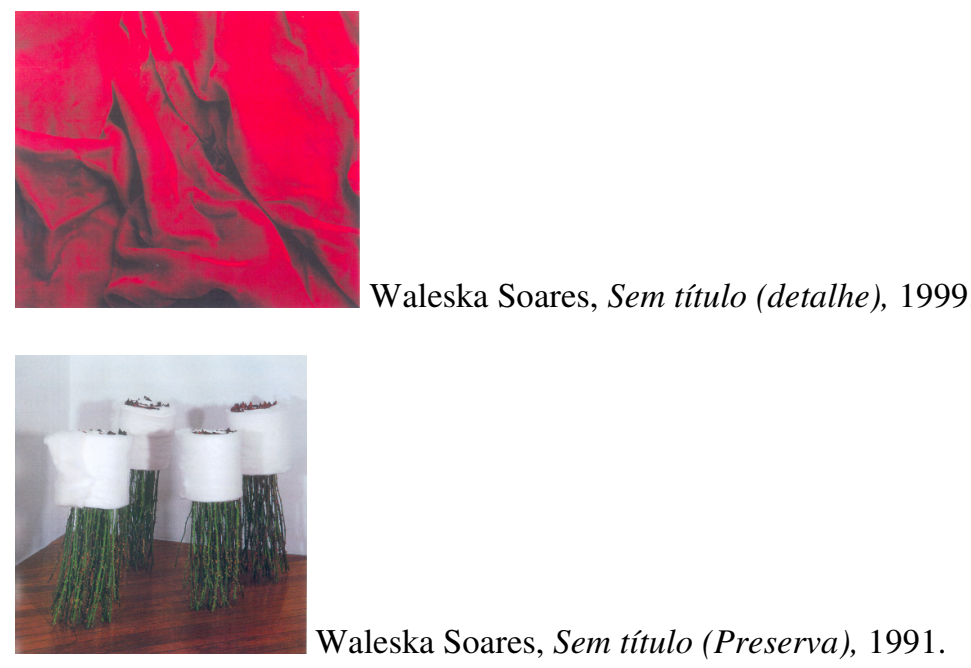


As rosas.Essa imagem e essa preferência não provém de um só artista ou de um só trabalho. É uma influência mais difusa. O uso da rosa é uma coincidência compartilhada por muitos, tanto na história da arte, quanto em situações menos eruditas: pense-se na moda e na estamparia de tecidos.

Houve, porém, um caminho tomado em relação ao desenho e à monotipia, que desemboca diretamente na aparência que hoje possuem as monotipias-rosas, o qual iniciou-se na admiração pelo grafismo de Giorgio Morandi.

Já foi mencionada a importância do desenho de observação como permanente exercício paralelo à produção artística, o qual toma depois, numa opção consciente, lugar relevante nessa mesma produção.

A forma como se desenrola esse processo é a de uma aproximação gradativa do desenho para a monotipia, sempre de observação, realizados ambos nos lugares escolhidos para esse fim, alla prima.

Era primeiro realizada com uma esferográfica a observação linear dos contornos dos elementos do entorno naquele que seria o verso do suporte da monotipia, sem ainda qualquer tipo de impressão do outro lado com tinta tipográfica preta.

A monotipia propriamente dita era feita depois sobre a entretela de algodão, material de textura e aparência rústicas, desenhando-se no verso, sem, contudo, incidir novamente com a caneta sobre as linhas de contorno já desenhadas, mas elaborando-se luz e sombra apenas com hachuras, nos intervalos entre as linhas traçadas, sem contornos aparentes, portanto. 
Mirella Mostoni, Sem título, 1998.

Encontram-se e são adotadas conscientemente nesse momento as soluções gráficas das gravuras de Morandi. O tratamento gráfico elaborado pelo artista, de hachuras que se entrecruzam perpendicularmente, que são sobrepostas tantas vezes quantas necessárias para se atingir o tom desejado.

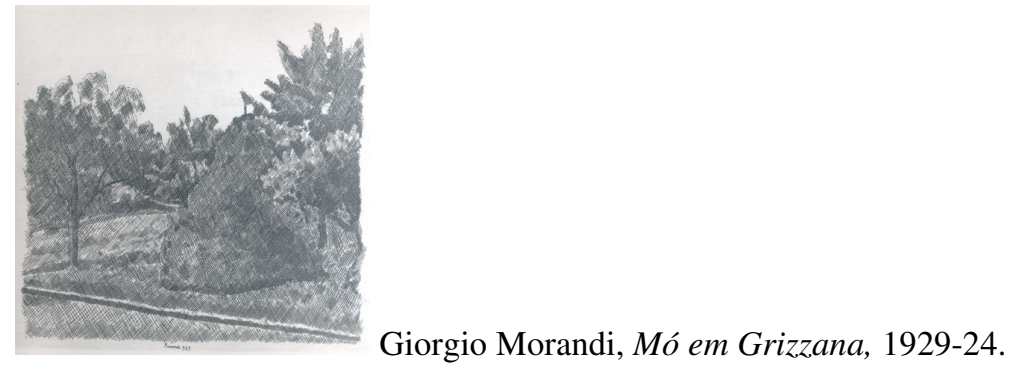

O grafismo admirado do artista permanece na impressão das rosas sobre o organdi, não tão evidente, dadas as características menos rústicas do tecido, mas ainda feito da mesma maneira, com gestos mais delicados e curtos, produzindo nesse contexto passagens tonais mais suaves. Em alguns trabalhos, porém, como nas Fendas Oraculares, é melhor perceptível o gesto, já que as dimensões ampliam os movimentos necessários para se obter o grafismo.

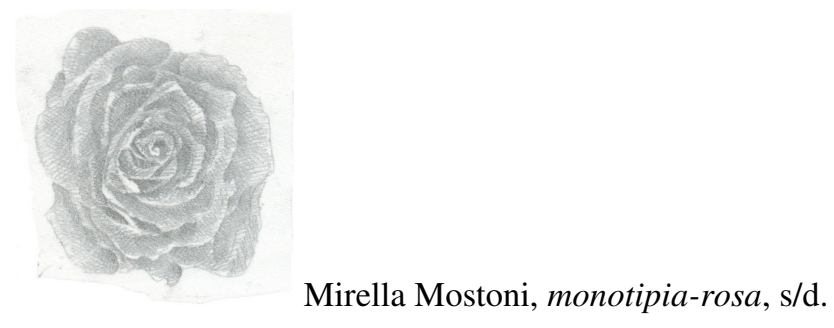

No momento em que surgem as monotipias-rosas as flores das naturezas-mortas de Morandi não constituíram influência direta ou procurada, embora haja semelhanças nascidas do mesmo tipo de grafismo, que proporciona valores tonais análogos. 
O tema das flores é constante na obra do artista, especialmente entre 1940 e 60, no desenho, na pintura e na gravura ${ }^{175}$. Morandi elabora suas composições observando flores de papel, feitas por ele próprio ${ }^{176}$. Une-as em arranjos de pequenos maços, justapostas, sobrepostas e compactamente unidas, produzindo obras nas quais essas flores denotam pouca definição morfológica ${ }^{177}$.

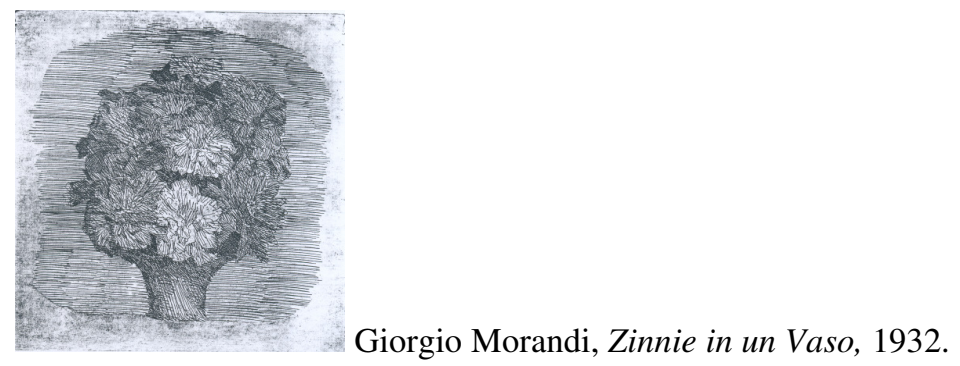

Ainda que o traçado das monotipias-rosas provenha da observação de flores naturais, o tratamento gráfico de luz e sombra não corresponde à incidência natural que a luz teria sobre uma rosa vegetal. O grafismo inventa para o desenho da rosa uma tridimensionalidade escultórica, que evidencia reentrâncias e proeminências idealizadas. Em comum com as flores de papel morandianas, as monotipias-rosas simulam naturalidade.

\footnotetext{
${ }^{175}$ Maria Elisa CEZARETTI. Olhar em Suspensão: Giorgio Morandi e a Natureza-morta. p.62.

${ }^{176}$ Como também era costume de Cézanne, era este um procedimento comum no âmbito das naturezasmortas, para que a passagem do tempo não afetasse os objetos que as compunham. Cf. Ibidem.p.61. ${ }^{177}$ Ibidem. p. 62.
} 
Segundo capítulo

Formula-te a ti mesmo

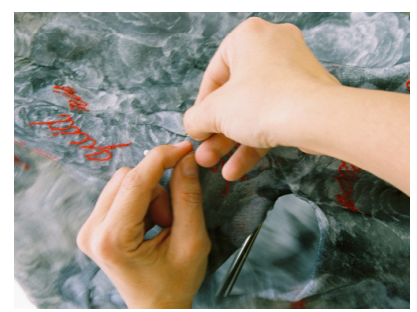




\section{Formula-te a ti mesmo}

"Os oráculos permanecem em aberto. Suas duplicidades e triplicidades

- são três as estradas que se cruzam próximo a Delfos são as da liberdade humana." ${ }^{178}$

George Steiner

\section{O Oráculo de Apolo em Delfos. A imagem escolhida}

Delphós foi um herói mitológico que deu seu nome à cidade sagrada de Apolo no Monte Parnasso: Delphoi.O personagem mata a serpente Píton e apossa-se do oráculo já existente $^{179}$.

Eram numerosos os oráculos consagrados a Apolo, deus revelador do devir. Aquele em Delfos era o mais importante e modelo para os muitos existentes ${ }^{180}$. Desempenhou papéis relevantes no mundo grego.

Numa dimensão política o oráculo era consultado para decidir-se na escolha e fundação do lugar destinado às novas colônias e onde em cada uma seria construído um novo oráculo. Num sentido moral, associava-se aos ritos de purificação que antecediam as predições; à importância conferida às suas respostas por consulentes de todas as

\footnotetext{
${ }^{178}$ George STEINER. Nenhuma Paixão Desperdiçada.p.309.

${ }^{179} \mathrm{O}$ nome do herói mítico é um adjetivo substantivado. Cf. Junito de Souza BRANDÃO. Dicionário Mítico-Etimológico da Mitologia Grega.p.270.

${ }^{180}$ Pierre LAVEDAN. Dictionnaire Illustré de la Mythologie et des Antiquités Grecques et Romaines.pp710-713.
} 
categorias sociais ${ }^{181}$. Filosoficamente, pelos motes admonitórios inscritos em seus muros ${ }^{182}$.

Há três elementos que distinguem um oráculo: um deus inspirador, um sacerdote transmissor da inspiração divina, um lugar determinado pela tradição ${ }^{183}$.

A consulta oracular seguia determinados procedimentos. Primeiro era oferecido um sacrifício. Os sinais de aceitação do deus que permitiam o prosseguimento da consulta eram dados pelos sintomas das sacerdotisas - as Pítias. Manifestações da ordem dos frêmitos, das palpitações, dos murmúrios convulsivos ${ }^{184}$.

Apolo revela diretamente sua vontade por meio da fala da Pítia, pronunciada em transe pela sacerdotisa sentada sobre uma trípode ${ }^{185}$.

Em pleno domínio apolíneo a palavra do oráculo era delirante. Não constituía manifestação do logos, mas expressava de forma tortuosa um conteúdo misterioso e obscuro. Na revelação do oráculo a admoestação apolínea do Conhece-te a ti mesmo encontra um obstáculo.

\footnotetext{
${ }^{181}$ Plutarco (50 d.C.-120d.C.) narra o episódio em que Alexandre obriga a Pítia a uma consulta fora dos dias pré-estabelecidos, trazendo-a à força para o templo de Delfos. Cf. LAVEDAN. Op.Cit. pp.710-713. ${ }^{182}$ Eis alguns: "Conhece-te a ti mesmo"; "A deus, a honra"; "Não tenha sentimentos além dos que convêm a um homem"; "Nada em demasia"; "Se te comprometes, eis a infelicidade". Cf. LAVEDAN. Op.Cit. pp.710-713.

${ }_{183}$ Pierre LAVEDAN, Op.Cit.pp.710-713.

${ }^{184}$ Pierre LAVEDAN, Op.Cit.p.710-713.Segundo Brandão antes de responder às perguntas dos consulentes a Pítia descia para uma cavidade no templo onde tocava o omphalós. Este autor ainda nos assinala que nunca foram detectados os vapores tóxicos nas fendas do templo, os quais, segundo a maioria das versões, seriam a causa do transe da sacerdotisa. Cf. Junito de Souza BRANDÃO .Dicionário Mítico-etimológico da Mitologia Grega. p.94-95. Uma das versões, porém, a de Diodoro da Sicília (historiador do século de Augusto) revela o quanto significava a idéia da presença desses vapores, inclusive para um dos mitos da fundação do oráculo, ao narrar que a atenção dos homens de Delfos foi atraída para a fonte dos vapores por meio de cabras que dançavam sob seus efeitos. A vontade de interpretação daquela teofania teria originado a instituição do oráculo. Cf. CHEVALIER e GHEERBRANT.Dicionário de Símbolos.p. 157.

${ }^{185}$ A trípode délfica era a insígnia da sabedoria apolínea, consagrada ao deus e símbolo da participação nos seus segredos. Símbolo das pulsões, um sinal da presença dos céus e alicerce da harmonia são alguns significados a ela atribuídos. Também objeto de uso cotidiano, servia como suporte para ânforas no aquecimento da água e para servir vinho em banquetes. No caso das trípodes de honra, estas eram oferecidas aos vencedores dos jogos ou dos coros. Cf. CHEVALIER e GHEERBRANT. Op.Cit..p.909.
} 
Frente às ambigüidades dos vaticínios havia exegetas especializados em esclarecer os sentidos das respostas recebidas. Estes poderiam ser livres ou nomeados pelo governante, charlatões ou não ${ }^{186}$.A ambigüidade não feria a crença na veracidade das previsões. Os erros nas ações subseqüentes à consulta eram antes atribuídos a enganos na interpretação das mensagens.O tom das predições tinha por finalidade conhecer o destino, não modificá-lo. Segundo Píndaro a lei universal tinha supremacia inclusive sobre os imortais. Nem aos deuses era dado mudar o destino humano ou evitar o inevitável ${ }^{187}$.

A ambigüidade do oráculo origina-se também da própria natureza de Apolo, o deus que faz surgir a consciência dos limites humanos, o Oblíquo ${ }^{188}$. Paradoxalmente à importância conseguida por seu oráculo, o deus demonstra em relação aos homens uma vontade de enganá-los: "Não diz, não oculta, mas envia sinais" ${ }^{189}$.

Lembremos aqui do espírito pessimista grego assinalado em $O$ Nascimento da Tragédia. O erro de julgamento num contexto opaco e ambíguo integrava o desígnio do destino. O erro humano é parte determinante e invencível de seu destino trágico: Homo sum $^{190}$.

\footnotetext{
${ }^{186}$ Pierre LAVEDAN. Op.Cit. pp.710-713.

${ }^{187}$ É conhecida a história de Creso, último rei da Lídia, que governou de 561 a 547 a. C. derrotado por Ciro II, rei da Pérsia. Ao consultar o oráculo sobre o destino que teria sua ofensiva sobre o reino do oponente, Creso interroga a Pítia a respeito da "destruição de um grande império". A resposta, dúbia mas exata: "Se Creso cruzar o rio Hális, destruirá um grande império". Cf. Junito de Souza BRANDÃO. Op.Cit. p.98.

${ }^{188}$ Vincenzo VITIELLO. Deserto Ethos Abbandono. p.148. Jacques DERRIDA e Gianni VATTIMO (org.). La Religione.pp.135-168.

${ }^{189}$ Heráclito referindo-se a Apolo. Ibidem. p.148.

${ }^{190}$ Até o fim da época helenística o oráculo continuava a ser consultado, acumulando-se ao seu redor as oferendas. A partir da época romana, o santuário passou a ser progressivamente abandonado. Cf. Enciclopédia Larousse Cultural.p.1804.
} 


\section{Os objetos-oráculo. A metáfora para a recepção.}

O que se vê ao se olhar para um dos oráculos do Conhece-te a ti mesmo?

Um corpo. Apresenta uma materialidade convidativa ao toque, maleável. Feito de tecido sobre o qual vêem-se desenhos impressos. A cor compõe-se de tonalidades que variam entre o cinza claro e o preto. Onde mais claro, menos matéria e mais transparência. Em cada impressão há uma organização interna que se repete analogamente em todas. Identifica-se o grafismo das monotipias. São flores. Rosas que se sobrepõem em acúmulos ou formam uma superfície.

São corpos com reentrâncias, investigáveis pelo olhar - ou pelas mãos, em alguns casos. No desenho encontram-se palavras, bordadas ou desenhadas em frases curtas. O planejamento geral do conjunto dos objetos prevê que mediante a beleza manifesta de sua aparência o espectador seja levado a investigar sua superfície à procura de respostas não evidentes para as perguntas que o próprio trabalho coloca.

Cada um dos oráculos deseja ser interpretado por meio da seqüência formada pelo título do conjunto, Conhece-te a ti mesmo, pelos títulos das séries nas quais se ramifica (Fendas Oraculares; Oráculos Portáteis; Tautologias) e as palavras finais: as respostas oferecidas.

A metáfora ${ }^{191}$ do oráculo também tem seus três elementos essenciais.

Se em Delfos havia o deus, o sacerdote e o lugar de consulta, nesta outra circunstância haverá um sujeito que se aproxima de um objeto sensível numa situação de encontro que prevê determinados espaço e tempo.

\footnotetext{
${ }^{191}$ Segundo Deleuze, metáfora é "(...) essencialmente metamorfose e indica como os dois objetos permutam suas determinações, e até mesmo a palavra que os designa, no novo meio que lhes confere a qualidade comum". Cf. Gilles DELEUZE. Proust e os Signos.p. 45.
} 
$\mathrm{O}$ ato de um sujeito que pergunta, interpreta, cria hipóteses ao se relacionar com uma obra de arte, atribuindo-lhe significados versa necessariamente sobre recepção. A natureza de tal atribuição contém em si uma aparente oposição antinômica e antitética; matéria há muito discutida: individuar se é por projeção ou apreensão de qualidades que se dá a recepção de uma obra de arte ${ }^{192}$.

A imagem do oráculo é perigosa. A partir de seu histórico e de sua natureza tende-se a acreditar que é apenas a projeção de quem interpreta é que lhe confere significado. Nietzsche parece pensar dessa forma quando escreve sobre a interpretação de um fenômeno comparando-a com a de um oráculo:

"Não acontece de outro modo com as loucuras e os delírios dos profetas e sacerdotes oraculares; foi sempre o grau de saber, fantasia, empenho, moralidade na cabeça e no coração dos intérpretes que tanto fez a partir dessas coisas" ${ }^{193}$.

É possível compreender a origem da discussão e do desequilíbrio entre os dois termos por meio do conceito de "processo de individualização" ${ }^{194}$, que se origina nas seguidas rupturas que ocorridas na história da produção artística desde o Renascimento.

Este processo teria originado uma crescente multiplicidade de códigos num contexto de produção e recepção antes restrito a poucos sistemas de signos amplamente dominados pelo público. Paulatinamente, a multiplicação e crescente individualização dos códigos artísticos afetou a relação das obras com os públicos aos quais destinavam-

\footnotetext{
${ }^{192}$ Estes dois termos são os empregados por S.Langer em Sentimento e Forma. Os conceitos de projeção e apreensão e suas respectivas teorias estéticas de origem serão adequadamente discutidos no decorrer do capítulo. A título de conceitualização inicial, cabem aqui duas definições básicas.

Projeção: inclui-se na teoria estética da empatia. No caso, "a fruição estética é a fruição de si próprio objetivado". O belo não estaria fora do Eu e do ato de consciência que o constitui. O belo não é coisa: é ato. Cf. Gianni CARCHIA e Paolo D'ANGELO. Dicionário de Estética.p.103. Tal definição coincide com as afirmações de Nietzsche e Langer.

Apreensão de qualidades: baseia-se na idéia de que as qualidades de uma obra permanecem constantes e livres da influência e prioridades do espectador. Desta forma as obras devem ser vistas individualmente por aquilo que são. A superação da projeção estaria na formação do juízo estético alcançado por meio da discussão e confirmação das percepções com outras pessoas. Cf. Stuart HAMPSHIRE.Logica e fruizione.p.198.

${ }^{193}$ Friedrich NIETZSCHE.Humano, Demasiado Humano.Aforismo 126.p.98. (grifo do autor).

${ }^{194}$ Jacques LEENHARDT. Recepção da Obra de Arte.In: Mikel DUFRENNE. A Estética e as Ciências da Arte.pp.62-67.
} 
se. O juízo estético aproximou-se do juízo de gosto ${ }^{195}$. Conseqüentemente ganharam peso na recepção a subjetividade e a projeção.

Para Langer uma mera escolha de um dos pólos da tensão existente entre apreensão ou projeção já constitui por si um problema. Por não serem ambos os termos complementares lógicos e por não se apresentarem numa relação de positivo e negativo: "estão simplesmente associados, respectivamente, com as negativas um do outro" ${ }^{196}$.

A simples exclusão de um dos termos apresenta-se para a autora como "uma difícil opção", cujo resultado seria o de apenas lançar a discussão estética no âmbito da definição da arte ou como expressão ou como impressão. Na primeira, apenas o artista estaria apto a julgar o valor do que faz. No outro extremo, representado pela segunda definição, o artista submeter-se-ia completamente ao julgamento do público, que passaria então a guiar o trabalho ${ }^{197}$.

A solução para o aparente impasse desta polaridade encontra-se evidentemente na complementaridade dos termos. As expectativas do que pode ocorrer com o espectador perante os oráculos do Conhece-te a ti mesmo serão construídas a partir de três caminhos de reflexão:

1. Ver o objeto-oráculo como possuidor de significados ambíguos e aberto à interpretação de quem o interroga. Uma abertura cujos limites para a projeção são dados pela própria obra ${ }^{198}$.

2. A beleza simultaneamente oculta e revela a fala do oráculo. Assemelha-se à idéia do véu expressa por Nietzsche. É forma de aproximação ao oráculo e encobre o inaudito dionisíaco da resposta. Terá função de acesso à leitura da obra, não

\footnotetext{
195 Jacques LEENHARDT. Op.Cit. pp.62-67.

${ }^{196}$ Susanne LANGER. Sentimento e Forma.p.18.

${ }^{197}$ Susanne LANGER.Op.Cit.p. 18.

${ }^{198}$ A partir de Umberto Eco em A Obra Aberta.
} 
constituindo apenas a aparência um fim em si, mas a beleza - se houver - será vista como êxito de todo o conjunto ${ }^{199}$.

3. O encontro entre consulente e oráculo é simbolicamente estabelecido nos atos do perguntar e do responder que se dará na relação dialética entre espectador e obra. Até que o espectador encontre sua pergunta na própria obra e, ao formular suas hipóteses, formula-se a si próprio na leitura oracular ${ }^{200}$.

Os mitos dos oráculos na história tomam acepções existenciais. Este tipo de busca sempre se relacionou com as angústias do viver. Ainda que neste caso não se enfatize a discussão da relação entre arte e vida. Aqui, o oráculo é metáfora da recepção. O título escolhido, Formula-te a ti mesmo, provém de uma idéia expressa na teoria do efeito estético de Iser, na qual o receptor, ao final do processo de leitura de uma obra de arte, também formula algo novo sobre si próprio.

A estética ${ }^{201}$ do Conhece-te a ti mesmo apresenta-se como a metáfora de um oráculo que, ao ser interrogado, devolve uma resposta ampla a quem o indaga.

Pensar a respeito desta poética, herdeira de um tipo de visão artística e filosófica, significará atualizá-la na recepção contemporânea, cujos mecanismos de leitura são próprios a toda arte moderna. Significará também localizá-la em relação a suas raízes que se estendem para trás no tempo, assumindo estas influências e seu valor estético, mas ao mesmo tempo propor no contexto contemporâneo o diálogo que a obra sugere a seu espectador, resolvendo o impasse de uma interpretação anacrônica.

Para atingir o objetivo proposto, será necessário, dado o forte apelo sensível da poética, investigar primeiro as origens e as modificações do conceito de belo, cotejando alguns aspectos à estética do Conhece-te a ti mesmo, atualizando por fim seu conceito segundo os três autores escolhidos sem renegar a prática artística.

\footnotetext{
199 A partir da teoria da formatividade de Luigi Pareyson.

${ }^{200}$ A partir da teoria do efeito estético de Wolfgang Iser

${ }^{201}$ O emprego das palavras estética e poética seguirá a diferenciação feita por Iser, no primeiro volume de $O$ Ato da Leitura,p.50. O autor diferencia o pólo artístico, o qual designa a obra criada pelo autor, do pólo estético, que indica a concretização produzida pelo leitor, a recepção da obra.
} 
Num segundo momento, a partir das três teorias eleitas, a metáfora do oráculo será devidamente situada na recepção contemporânea - por meio de determinados pontos de apoio em cada teoria - e, por fim, será analisada a relação dialética entre obra e espectador, a questão principal. 


\section{Sobre a beleza}

A beleza desempenha na história da cultura um papel que sofre grandes transformações. Nasce como conceito universal, é posteriormente associada ao universo da estética, assumindo aí uma determinada face e função que, com algumas variações, prolonga-se até o século XIX.

Na modernidade, dentro da estética e na produção dos artistas, ocorre um rompimento com os cânones que separou definitivamente o conceito de beleza artística do horizonte platônico, até prescindir-se do termo.

Para Platão o belo associava-se ao bem e à virtude. Era delimitação e ordenação do ilimitado ${ }^{202}$, características que vão ao encontro da concepção apolínea de beleza. Platão valoriza a Idéia e, portanto, as artes que possuam cânones e não originalidade ${ }^{203}$.

Há um estranhamento hoje em relação à palavra "beleza", fato reconhecido por vários autores que se resume na percepção de Dorfles ao assinalar o desfavor no qual o termo caiu para muitos estudiosos de estética, tendo quase desaparecido dos discursos sobre questões artísticas ${ }^{204}$.

Esse fenômeno fortaleceu-se na modernidade, quando outros valores são associados à beleza, inclusive suplantando-a ao minar conceitos antes resistentes a mudanças. Já no século XX Valéry faz o seu Fedro contestar a Idéia do belo platônico, quando a define como "excessivamente simples", uma idéia que excluía a diversidade, a mudança, as novas criações, os esquecimentos e as ressurreições ${ }^{205}$.

\footnotetext{
${ }^{202}$ Gianni CARCHIA e Paolo D'ANGELO. Op.Cit.p.55.

${ }^{203}$ Erwin PANOFSKY. Idea: A Evolução do conceito de Belo.pp.07-08.

${ }^{204}$ Gillo DORFLES. Le Oscillazioni del Gusto,p.39.

${ }^{205}$ Paul VALÉRY. Eupalinos, ou O Arquiteto.p. 43.
} 
Desaparece o termo, mas não sua misteriosa e inconfundível manifestação sensível. Como sentir, receber e refletir sobre a bela aparência que se oferece numa poética contemporânea? ${ }^{206}$

O conceito de belo toma duas acepções no decorrer da história: a primeira, na antigüidade, pertence à doutrina universal do ser; a segunda, ao tornar-se categoria da estética $^{207}$.

Dentro da estética encontramos também dois momentos distintos de conceitualização do belo: uma forma clássica, pré-moderna, seguida por uma anticlássica, que se constrói a partir do século XIX, com o Romantismo ${ }^{208}$.

No conceito clássico do belo as palavras-chave são ordem, medida, proporção e perfeição. Tanto em Aristóteles quanto em Platão o belo está ligado ao conceito pitagórico matemático de medida, eterno e universal ${ }^{209}$, o qual ainda pode ser ouvido ecoando, ao pensarmos numa das fontes na qual bebe o Conhece-te a ti mesmo, na justa medida representada por Apolo em $O$ Nascimento da Tragédia.

A ordem cósmica é a metáfora suprasensível e absoluta da beleza. Seus elementos são a proporção, a simetria e a ordem, qualidades regulares e eternas da natureza que contrastam com as irregularidades humanas ${ }^{210}$. O belo relaciona-se com a virtude e o bem, relação esta que se dá pela passagem direta da esfera dos sentidos para a esfera moral e espiritual.

\footnotetext{
${ }^{206}$ Bodei aponta oito modificações objetivas da beleza no século XX. São: a) a subjetividade atribuída ao gosto e ao juízo estético nele baseado; b) a afirmação de uma poética do "vago"; c) a beleza funcional; d) a complicação ou a simplificação dos princípios da beleza; e) o belo como esplendor; f) a busca de uma beleza para além do tangível, de características platônicas; g) o belo como expressão, não contido na harmonia ou simetria; h) a projeção do belo para além de uma medida concebível, para o 'sublime'. Cf. Remo BODEI. As Formas da Beleza.p.48.

${ }^{207}$ Gianni CARCHIA e Paolo D'ANGELO. Op.Cit.p. 52.

${ }^{208}$ Ibidem. p. 51.

${ }^{209}$ Ibidem. p.52.

${ }^{210}$ Hans-Georg GADAMER. A Atualidade do Belo.p.27.
} 
A estética de $\mathrm{S}$. Tomás de Aquino prolonga e elabora esses conceitos em três questões essenciais. A primeira, encontra a beleza na adequação aos cânones da arte, unindo-a à verdade. A segunda encontra a beleza na justa proporção e na harmonia entre as partes. Neste cenário a filosofia tomista acrescenta uma terceira marca distintiva da beleza: a claritas, a luminosidade, um esplendor que fascina e comove através do sentido da visão ${ }^{211}$.

A claritas é um dado novo que inaugura conseqüências no desenvolvimento posterior da idéia do belo. Por meio da luz é que a beleza se torna visível na esfera do sensível; a primeira é causa da segunda, já que a beleza é vista graças à claritas. Mas esta é também a própria luz do espírito, aquele específico esplendor sentido para além do cânone. Por exemplo, em duas obras que se mostrem igualmente belas, a claritas pode estar presente em apenas uma ${ }^{212}$.

Este conceito nos mostra a natureza da beleza como uma manifestação sobre a qual a simetria, a proporção e a ordem se fundamentam, o que já não é o mesmo que simplesmente pensar que a beleza surge e é garantida pela presença das características canônicas $^{213}$.

A metafísica antiga da luz reverbera na posterior noção estética de "aparência", na idéia decorrente de "bela aparência", na associação do belo com "imagem", algo que é sorvido pelos olhos, até a estética de Kant, na qual o belo é idéia que se manifesta como fenômeno ${ }^{214}$.

Temos daí o conceito de belo determinado pela aparência, que começa a dialogar com a sensibilidade do olhar, herdeiro da claritas, sem fins utilitaristas. Pois o belo, segundo Gadamer, "preenche-se numa espécie de auto-definição e respira prazer na auto-representação" 215 .

\footnotetext{
${ }^{211}$ Gianni CARCHIA e Paolo D'ANGELO. Op.Cit. p. 53.

${ }^{212}$ Ibidem. p.53.

${ }^{213}$ Ibidem. p.53.

${ }^{214}$ Ibidem..p.51-55.

${ }^{215}$ Hans-Georg GADAMER.Op.Cit.. p.26.
} 
É relevante assinalar a associação entre o belo e a imagem. Na teoria de Iser, o efeito estético se dá por meio da imagem que se forma na mente durante a leitura de um texto através da imaginação do leitor.

Mas, diante de uma imagem de uma obra de artes plásticas formamos uma outra imagem? A resposta está numa das fontes de Iser: a obra O Imaginário, de Sartre, na qual o autor investiga a natureza e a função das imagens como pensamento na consciência.

Ambos os processos, percepção visual e leitura, realizam-se pela visualização dos significantes, formas e palavras impressas, pela consciência. Mas a compreensão, fato assumido pelos dois autores, se dá na imagem, por meio da imaginação, não pelo discurso sobre a imagem ${ }^{216}$.

Enquanto se percebe não se formam imagens, pois percepção e imaginação são duas atitudes irredutíveis da consciência ${ }^{217}$. A apreensão da imagem está para além da percepção. Portanto o objeto estético não é o objeto físico produzido pelo artista que se dá à percepção, mas a imagem que dele criamos, fruto também da projeção da experiência do leitor/espectador ${ }^{218}$.

As épocas que se seguem continuam julgando a beleza segundo normas préestabelecidas de harmonia, referência matemáticas e exemplos da antigüidade. Segundo Alberti a beleza estava na harmonia das proporções, no acordo das partes com o todo e nas cores e qualidades sensíveis, o que revela que, ao lado do julgamento referencial nasce uma concepção que renuncia à metafísica da beleza e olha diretamente para o fenômeno, começando assim a dissociarem-se o "belo" do "bem" platônicos e conferindo autonomia à esfera da estética ${ }^{219}$.

\footnotetext{
${ }^{216}$ Jean-Paul SARTRE. O Imaginário. p.96.

${ }^{217}$ Ibidem.p. 160.

${ }^{218}$ Ibidem. .p. 246.

${ }^{219}$ Erwin PANOFSKY.Op.Cit..p.54.
} 
No século XVIII, quando a estética se constitui como disciplina autônoma, encontramos a arte sob a denominação de "belas-artes".

Num sentido possível deste conceito, a arte é uma atividade ligada ao sentido de técnica e de produção artesanal, modo de pensar transmitido desde Aristóteles, que ligava a arte ao conhecimento e à capacidade de fabricação, ambas com pontos comuns inegavelmente ${ }^{220}$.

Por outro lado, a Estética leva a filosofia a refletir sobre o belo e, ao associar arte e beleza, separa o artista do artífice, tornando as belas-artes objeto superior, desvinculado de uma utilidade prática e concentrando sua importância na experiência sensível por ele proporcionada ${ }^{221}$.

O que quer que fosse definido como beleza, a associação desta com a arte constitui uma conquista intelectual que mudou o lugar desta última na hierarquia do que o homem é capaz de produzir. O objeto artístico, autônomo em sua beleza característica, individual e particular em cada obra de arte, apresenta-se como fim em si mesmo e aberto à receptividade ${ }^{222}$.

Na estética do século XIX a beleza ainda é entendida como uma lei geral da arte, que se conservava acima das mudanças de poéticas, possuía vários modos de manifestação e assim permitia juízos de valor constantes e seguros ${ }^{223}$. As poéticas poderiam contrariar a ordem desse código, nele introduzindo figuras originais, mas dentro do limite imposto pelo respeito à regra ${ }^{224}$.

Havia um sistema de explicação sob a responsabilidade do crítico, revelador do sentido único e referencial da obra, a qual carregava consigo uma mensagem dela

\footnotetext{
${ }^{220}$ Hans-Georg GADAMER. Op. Cit.,p.24.

${ }^{221}$ Mônica TAVARES. Fundamentos Estéticos da Arte aberta à Recepção. p.31-32.

222 Ibidem, p.32.

${ }^{223}$ Luigi PAREYSON. Os Problemas da Estética.p.181.

${ }^{224}$ Umberto ECO. A Obra Aberta.p.124.
} 
separável e que lhe ratificava o caráter de arte. Neste sentido a arte é vista como "forma representativa" ${ }^{225}$, organon da verdade, via de acesso do homem à própria essência ${ }^{226}$.

Mas é no próprio século XIX que é detectada por Hegel a "quebra de uma tradição uniforme", por meio da qual a arte deixa de ser uma das portas abertas para o absoluto, deixando de ter seu papel determinado por um contexto que a justificava. A verdade para o artista passa a ser apenas sua própria forma e mensagem, o que destrói a contemplação intuitiva e a contemplação guiada pela referência à natureza ${ }^{227}$.

A beleza canônica é substituída pela revelação de uma interioridade ${ }^{228}$, coincidente ou não com as leis do belo. Distancia-se da arte a idéia de beleza construída até esse momento.

Para Valéry a beleza na modernidade torna-se construção do espírito cujo domínio é intraduzível em teorias. Sua tradicional conotação se vê suplantada por "valores de choque": a novidade, a intensidade, a estranheza. Conceitos novos relacionados à vida psíquica e sensitiva, o inconsciente, o irracional, o instantâneo e a originalidade, principalmente ${ }^{229}$.

A arte torna-se tarefa para a reflexão, questão já pré-formulada por Hegel, e passa a exigir "um trabalho de elaboração ativa", ao frustrar as expectativas figurativas de seu público ${ }^{230}$.

Os autores escolhidos para analisar a recepção atualizam essas questões.

Sobre a beleza encontramos em Eco o desaparecimento do termo, substituído pelo conceito de valor estético, que seria, primeiro, "a capacidade do discurso estético

\footnotetext{
${ }^{225}$ Hans-Georg GADAMER.Op.Cit..p.33.

${ }^{226}$ Wolfgang ISER.O Ato da Leitura. Vol. II.p.29 e 37.

227 Hans-Georg GADAMER. Op.Cit.p.14-18.

${ }^{228}$ Luigi PAREYSON. Op.Cit. p.181-182.

${ }^{229}$ Paul VALÉRY. Leonardo e os Filósofos.p.195 e 206.

${ }^{230}$ Hans-Georg GADAMER. Op.Cit. p.18-20.
} 
de manifestar uma visão de mundo e suas ligações com a cultura contemporânea" e, segundo, a informação estética entendida como leitura múltipla de uma linguagem "que funda em si múltiplos elementos" ${ }^{231}$.

Em Iser encontramos que quanto à questão de ser a obra de arte "a autorepresentação da consciência, não caberia ao leitor outra atitude senão contemplá-la; assim, no entanto, se avivaria o ideal da estética clássica graças a um objeto moderno: em vez da beleza, teríamos agora a consciência" ${ }^{232}$.

Considerar a arte como manifestação da universalidade nos levaria a uma interpretação unívoca, o que vai de encontro ao conceito de ambigüidade característico da arte moderna proposto na Obra Aberta e contra a relação da arte com seu contexto de produção e o contexto social de recepção no qual se insere, como defende Iser.

Pareyson recoloca o conceito de beleza, vendo-o como resultado e não objeto da arte.. Desse modo, um objeto de arte é belo se atinge seu efeito: a obra "é bela porque artística" e não artística porque confirma a beleza de seu referente . Não existe uma lei da beleza, mas a inventividade e a originalidade de quem cria. A regra é individual ${ }^{233}$.

"A única lei da arte é o critério do êxito". O êxito é o impacto, o efeito estético e $\mathrm{o}$ acesso à sua leitura causado naquele que a lê ${ }^{234}$. A beleza, portanto, está no impacto causado pela obra, a beleza é o efeito estético, o que nos aproxima da teoria de Iser e permite abordar o impacto causado pelo Conhece-te a ti mesmo para um passo além da aparência.

\footnotetext{
${ }^{231}$ Umberto ECO. Op.Cit. p.154.

${ }^{232}$ Wolfgang ISER.Op.Cit.vol.II.p.87.

${ }^{233}$ Luigi PAREYSON.Op.Cit. p.181-182.

${ }^{234}$ Ibidem, p. 184.
} 
Aqui há uma ponte entre as teorias da formatividade e a do efeito estético. A obra é bela porque alcança êxito e este ocorre no impacto que causa: "a beleza está no efeito estético" 235 .

A poética do Conhece-te a ti mesmo não renega sua opção consciente pela bela aparência, mas não funda apenas nela seu efeito estético. A beleza aparente é a chave de acesso ao efeito estético.

${ }^{235}$ Ibidem, p. 184. 


\section{É papel do artista discutir a recepção?}

Toda obra de arte é, em determinado grau e modo, aberta à interpretação por excelência, mas, antes do final do século XIX e do manifesto simbolista o era de maneira inconsciente para autor e espectador. $\mathrm{O}$ autor e seu contexto cultural ofereciam vários níveis de leitura para quem fruía a obra, porém com significados préestabelecidos. É o que Eco chama de "a poética do unívoco", referindo-se a esta arte como clássica ${ }^{236}$.

O modo contemporâneo de aproximar-se, de ler uma obra de arte é o modelo proposto de obra aberta, isto é, pressupõe a obra como intencionalmente aberta e plurívoca. Logo, neste cenário em que quase tudo parece ser possível, haveria cabimento para que o criador se preocupasse com a recepção da própria obra?

Primeiro devem ser descartadas as interpretações empobrecedoras dessa discussão. Não é papel do artista propor um modelo de recepção nem pensar na análise crítica da própria obra. A partir do momento que se completa, começa uma nova existência para um trabalho, o que torna seu criador também leitor. Mas, inegavelmente existiu uma intenção criadora e, por conseguinte, um leitor implícito ${ }^{237}$.

A identidade complexa do oráculo, assim como é complexa a identidade de toda obra de arte, e suas raízes que se entranham em níveis antigos da filosofia e da estética situam-se no contexto contemporâneo de recepção. Após finalizar a obra o artista também se torna espectador e leitor, podendo indagar ao oráculo a natureza de sua identidade.

\footnotetext{
${ }^{236}$ Umberto ECO. Op.Cit. p.43-44.

${ }^{237} \mathrm{O}$ conceito de leitor implícito, de Iser, é uma concepção que se funda na estrutura da obra e antecipa a presença do receptor, sem existência real. A função do leitor implícito é a de cooperar de forma ampla e semelhante às intenções do autor na produção de significado ao materializar o conjunto das preorientações oferecidas por uma obra "como condições de recepção a seus leitores possíveis", mas sem determiná-las. Op.Cit. vol. I.p.73.
} 
Na estética do Conhece-te a ti mesmo tudo é aparentemente tradicional. Os meios de produção totalmente manufaturados; o uso de uma forma ornamental com referência na natureza - a rosa; a visível busca de qualidades da beleza puramente contemplativa: a perfeição, a harmonia, a proporção; a decidida opção em propiciar prazer visual e tátil; a referência ao que se pode confundir a uma moral unívoca: a apresentação de uma verdade nas palavras bordadas. Localizaria-se então essa poética numa concepção e recepção pré-modernas?

A solução para o impasse está na relação entre diacronia e sincronia que se apresenta no trabalho. Nos fatos estéticos que ocorrem sincronicamente na obra, há novos sentidos anexados aos processos antigos que continuam reverberando ao longo do tempo.

O oráculo implica num tipo de relação entre um ser que, desconhecendo, pergunta sobre algo a uma alteridade, que, de alguma forma, representa um conhecimento que é expresso de forma ambígua. $\mathrm{O}$ oráculo deixa a seu consulente a difícil tarefa da decifração, cujo significado final oscila entre as projeções e experiências de quem pergunta e a tentativa de apreensão do novo, buscado naquele que lhe responde.

A relação dialética entre obra e espectador manifesta-se na metáfora da pergunta e resposta oraculares e confirma-se nas teorias da formatividade, da obra aberta e do efeito estético. 


\section{Contribuições teóricas}

Julio Plaza situa a abertura da obra de arte no que concerne à recepção, relacionando-a às três fases produtivas da arte: a obra artesanal (imagens de primeira geração), a industrial (de segunda geração) e eletro-eletrônica (terceira geração), atribuindo vários graus à interpretação ${ }^{238}$.

Ao se pensar "a inclusão do espectador na obra de arte" proposta pelo Conhecete a ti mesmo, vê-se que esta situa-se nas imagens de primeira geração, com abertura de primeiro grau e participação do espectador ao nível da contemplação, percepção imaginação, evocação, etc. ${ }^{239}$.

A abertura de primeiro grau é caracterizada por Eco e remete à polissemia, à ambigüidade, à multiplicidade de leituras e riqueza de sentidos ${ }^{240}$. O conceito de arte, neste contexto, é tratado como "uma mensagem fundamentalmente ambígua, uma pluralidade de significados em um só significante" ${ }^{241}$.

\footnotetext{
${ }^{238}$ Julio PLAZA."Arte e Interatividade: autor-obra-recepção". p.09. Ars, Revista do Departamento de Artes Plásticas. ECA/USP.n. 2, p.9-29. Dez 2003.

${ }^{239}$ Ibidem. p.10.

${ }^{240}$ Op. Cit., p.9.

${ }^{241}$ Ibidem, p. 11 .
} 


\section{A teoria da formatividade}

A teoria da formatividade de Pareyson ${ }^{242}$ propõe a arte como unidade indivisível entre o conhecer, o exprimir e o fazer, com ênfase neste último. A arte é uma produção manual, fabril e espiritual ${ }^{243}$.

Aqui há três pontos de apoio para a estética do Conhece-te a ti mesmo. $\mathrm{O}$ conceito de beleza recolocado, como já discutido anteriormente. A definição de arte que abrange o processo criativo tradicional desta poética e a idéia de colóquio entre obra e espectador que confirma a dialética da recepção ${ }^{244}$.

Pareyson também realiza a aproximação entre a recepção da palavra e das artes plásticas, o que lança uma ponte entre estas últimas e a teoria de Iser, voltada para o texto literário ${ }^{245}$.

$\mathrm{O}$ autor parte do fazer e atinge o conceito de arte como formatividade, descrevendo-o como:

"um tal fazer que, enquanto faz, inventa o por fazer e o modo de fazer. A arte é uma atividade na qual execução e invenção procedem pari passu, simultâneas e inseparáveis, na qual o incremento de realidade é a constituição de um valor original" 246.

Este fazer é um "formar", um "executar, produzir e realizar, que é, ao mesmo tempo, inventar figurar, descobrir" 247.

\footnotetext{
${ }^{242}$ A teoria data de 1954. Os problemas da Estética, que reúne os pontos essenciais da teoria, é de 1966.

${ }^{243}$ Mônica TAVARES. "Fundamentos Estéticos da Arte Aberta à Recepção".p.39.Ars. Revista do Departamento de Artes Plásticas. ECA/USP.n.2, p.31-43, Dez 2003.

${ }^{244}$ Questões desenvolvidas pelo autor nos capítulos IX e X: O Processo Artístico (pp.181-200) e Leitura da Obra de Arte (pp.201-242).

${ }^{245}$ Esta análise encontr-se no item Interrelações entre palavra e imagem neste mesmo capítulo.

${ }^{246}$ Luigi PAREYSON. Op. Cit. p.26.

247 Op.Cit., p.26.
} 
A atividade artística tem um caráter formativo que inventa e executa. Nela, criase uma forma que é "exemplar na sua perfeição e singularíssima na sua originalidade" 248

Há elementos da formatividade nos quais encontra-se correspondência com a poética do Conhece-te a ti mesmo. A idéia de produção manual e fabril manifesta-se fortemente no processo de produção das obras, por meio da manufatura e da repetição como atividade incessante. Repetição de todos os passos da monotipia, repetição dos desenhos e grafismos, repetição da costura que constrói paulatinamente o objeto final, repetição dos gestos que constituem a natureza do trabalho (por exemplo, o acúmulo, o recorte que pode retirar matéria em prol da leveza e da transparência, a repetição dos pontos do bordado).

Também é terminante a idéia da forma acabada que busca atingir sua própria perfeição, que para Pareyson, é quando a formação da obra atinge sua totalidade, sua completude $^{249}$.

O ato da execução de uma obra, que se efetua e se inventa ao mesmo tempo, evidencia-se no processo da montagem da obra, passível de idas e vindas, reformulações inerentes à natureza do trabalho, que não guarda marcas de refazimentos, quando ocorrem.

Uma das questões essenciais para o Conhece-te a ti mesmo é que a teoria da formatividade vê o objeto de arte como organismo em transformação: uma forma,

\footnotetext{
${ }^{248}$ Ibidem, .p.26.

${ }^{249}$ Ibidem. p.196. A idéia da perfeição, embora historicamente ligada à da beleza, relacionou-se com esta de forma controversa. Para Aristóteles a perfeição seria uma totalidade não-defeituosa, completa em todas as suas partes, ou ainda, uma realidade conforme à sua essência (próxima da idéia de Pareyson). Na estética moderna Baumgarten define a beleza como "a perfeição do conhecimento sensível". Já para Kant a perfeição está na idéia da beleza correspondente à sua função, onde o juízo não prescinde da totalidade da coisa. O conceito de perfeição na beleza que supera a controvérsia é o clássico, no qual a perfeição é requisito da obra que se apresenta como modelo, estabelecendo uma relação tautológica entre beleza e perfeição. Cf. Gianni CARCHIA e Paolo D'ANGELO. Op. Cit.pp.275-276 Novamente o conceito aproxima-se das idéias Pareyson, quando se retoma sua elaboração sobre a exemplaridade de uma obra de arte bem-sucedida. Cf. Luigi PAREYSON. Op.Cit. p.196.
} 
formada e formante, que estimula a recepção e que deve ser interrogada pelo espectador 250

Pareyson apresenta dessa forma a idéia de colóquio entre espectador e obra.

Delimita-a como uma relação de pergunta e resposta ${ }^{251}$. No Conhece-te a ti mesmo a forma torna-se formante por meio da dialética estabelecida entre obra e espectador mediante a metáfora do oráculo.

${ }^{250}$ Mônica TAVARES. Op. Cit. p.39.

${ }^{251}$ Luigi PAREYSON. Op. Cit. p.207. 


\section{A teoria da obra aberta}

Na teoria da Obra Aberta uma obra de arte é uma organização de efeitos comunicativos. Estes são estímulos à sensibilidade e inteligência do espectador, que elabora "um jogo de respostas" 252.

O estímulo estético é construído pelo criador da obra, cuja intenção é a de que seus significados se enriqueçam à medida que se dêem leituras sucessivas de sua obra (conceito de sugestão orientada) ${ }^{253}$, sem que se passe por cima da intenção do artista, que é a de que "a obra seja fruída tal como ele a produziu" ${ }^{254}$.

Neste primeiro conceito de apoio vêem-se algumas afinidades. Primeiro com a idéia do estímulo. Depois, com o ato do espectador que elabora respostas e, conseqüentemente, estabelece uma relação dialética de perguntas e respostas na relação com a obra, na qual a ambigüidade e a leitura múltipla estejam submetidas a uma intenção criadora.

Umberto Eco tece sua Obra Aberta ${ }^{255}$ a partir de Pareyson, mas diferencia-se deste em dois pontos: pensa a poética da abertura da obra como programática na arte moderna, isto é, mais explícita e decidida. Eco considera a abertura "a possibilidade fundamental do fruidor e do artista contemporâneo" ${ }^{256}$, a vocação da arte moderna. Seu foco volta-se mais para a obra de arte a partir de seus critérios operativos do que como produto final.

\footnotetext{
${ }^{252}$ Umberto ECO. Op.Cit.p.40.

${ }^{253}$ Neste conceito encontra-se o "estímulo estético". A sugestão orientada é um mecanismo premeditado e construído por um autor para provocar certas emoções e significados que não se esgotem nas sucessivas leituras, mas, ao contrário, que se enriqueçam. A forma como é elaborada esta sugestão é determinante para sua eficácia, no sugerir conotações. Ibidem,p.78-82.

${ }^{254}$ Ibidem, p.40.

${ }^{255}$ O livro é de 1969.

${ }^{256}$ Umberto ECO. Op. Cit. pp.64-65.
} 
A abertura programática é o segundo conceito de apoio, no qual há quatro características afins à poética do Conhece-te a ti mesmo:

1. É escolhida pelo artista como programa produtivo, propondo a obra "de modo a promover a maior abertura possível" 257.

2. A condição dessa abertura é ambigüidade da obra ${ }^{258}$. No significado ambíguo "cada significante significa de modo vago" podendo apenas ser lido como pertencente a um todo ${ }^{259}$. Temos então que a mensagem estética é uma mensagem ambígua, "indica ao destinatário que era possível usar o código de modo inusitado" ${ }^{260}$, que é exatamente o que ocorre com os códigos utilizados no Conhece-te a ti mesmo.

3. A partir da noção tradicional de obra de arte que se comunica como fisionomia única, a obra aberta apresenta "uma intenção a priori que a torna disponível para várias integrações" ${ }^{261}$.

4. Um dos três tipos de obra aberta - o segundo - é o da obra fisicamente completa, mas aberta "a uma germinação contínua de relações internas que devem ser descobertas e escolhidas pelo fruidor dentro da totalidade da obra" 262.

O terceiro ponto de apoio é a linguagem da obra. É possível o uso de convenções de linguagem comum para a criação de uma obra aberta, a qual, embora possa apresentar códigos e referentes já estabelecidos por uma tradição, mesmo assim pode situar-se no contexto da produção contemporânea por meio do uso que faz desses códigos $^{263}$.

Para a abertura de uma obra não é importante se são usadas convenções da linguagem comum (técnica, referente, códigos de representação ou estéticos). Importa sim se a obra "fundamenta seu valor justamente numa novidade de organização do material disponível", o que para o leitor sempre constitui um acréscimo de informação 264.

\footnotetext{
${ }^{257}$ Ibidem,p.42.

${ }^{258}$ Ibidem,p.47.

${ }^{259}$ Ibidem, p.84-85.

${ }^{260}$ Ibidem,p. 121.

${ }^{261}$ Ibidem, p.63.

${ }^{262}$ Ibidem, p.63-64.

${ }^{263}$ Ibidem. p. 162.

${ }^{264}$ Ibidem, p. 163.
} 


\section{A teoria do efeito estético}

$\mathrm{Na}$ teoria do efeito estético de Iser ${ }^{265}$ encontram-se os principais pontos de identificação com a estética do Conhece-te a ti mesmo. Em sua essência, é conhecida intuitivamente por muitos artistas. Por este motivo, o autor deseja atingir por meio dela "uma estrutura subjetiva passível de descrição" ${ }^{266}$.

Esta teoria propõe a constituição de um sentido que se formule a partir da própria obra através de uma relação dialética entre obra e leitor e a interação de ambos. A formulação de sentido por parte do leitor se dá através do preenchimento dos vazios existentes na estrutura de uma obra originados pelo "não-dito", o que exige uma definição deste conceito.

Uma obra forma um sistema ${ }^{267}$ de elementos combinados, entre eles o não-dito, isto é, os lugares vazios que a obra abriga. A característica dos lugares vazios é a de que só podem ser ocupados por um outro sistema que não o da própria obra, mas pelo sistema de representações do leitor, se estas se desenvolverem sob as condições estabelecidas pelo texto ${ }^{268}$. A obra se concretiza na leitura e o leitor é visto como um ser inserido num contexto ${ }^{269}$.

\footnotetext{
${ }^{265}$ As teorias do autor sobre a leitura datam dos anos 70. O Ato da Leitura é de 1987.

${ }^{266} \mathrm{O}$ autor ressalta que sua teoria não é de recepção, por considerar esta fundada nos juízos históricos dos leitores. Defini-la como teoria do efeito estético significa, para Iser, ancorá-la diretamente no texto - na obra de arte - e vê-la como "uma reformulação de uma realidade já formulada. Através dessa reformulação advém algo ao mundo que antes nele não existia". Cf. Wolfgang ISER. O Ato da Leitura, vol. I.p. 11-16.

${ }^{267}$ Na definição de Iser, sistema é um paradigma, convenção de linguagem, organização dos elementos subordinados de uma linguagem. O sistema engloba os objetos que dele fazem parte e subordina sua significação ao seu contexto, fazendo-os interagir em completude. Destina-se a facilitar a comunicação e diminuir a resistência a ela, engendrando seu próprio estímulo estético a partir do conjunto. Se o sistema se rompe, isto é, se apresenta vazios, o receptor se defronta com a significação própria do objeto afastado do contexto. Desse modo, ao deparar-se com a individualidade de cada elemento, é obrigado a fazer relações mais abrangentes. Ibidem, vol.I. p.40-41.

${ }^{268}$ Ibidem vol.I, p.107.

${ }^{269}$ Ibidem,vol.I.p. 47-48.
} 
Interessam nesta teoria o conceito citado acima, meio de produzir o efeito estético e, principalmente, o ápice deste processo: a formulação da obra realizada pelo leitor, quando este preenche as lacunas da estrutura da obra, o que lhe propicia sua própria formulação como ser ${ }^{270}$.

É também relevante o processo de leitura ${ }^{271}$, que mostra "o potencial de efeitos" de uma obra -- idéia análoga à plurivocidade de Eco e que se contrapõe à interpretação única.

A idéia do "não-dito" está presente no que é dito, é acessível apenas mediante a ocorrência do efeito estético, também chamada pelo autor de "não-dado" e "não formulado" ${ }^{272}$. O não-dito, o que é deixado à atividade imaginativa do leitor, é a característica do efeito estético. Não é dado no mundo, só pode ser propiciado por uma obra de arte; mas não está nela formulado diretamente: surge na comunicação entre leitor e obra ${ }^{273}$.

O conceito de vazio também se manifesta numa realidade percebida visualmente. Em $O$ Imaginário, Sartre considera que, no nível da percepção apreende-se um objeto englobado num conjunto e, se uma parte desse objeto está oculta, pode-se completá-la a partir de sua própria ausência, através de seu contexto visual ${ }^{274}$.

Na poética do Conhece-te a ti mesmo há exemplos desse tipo de vazio dado pelo ocultamento. A sobreposição das monotipias-rosa; a elisão, proposital ou não, da palavra bordada ou de partes dela dentro de um trabalho causam esse efeito de procura pela imagem global, de tentativas sucessivas de preenchimento para se atingir um todo.

\footnotetext{
${ }^{270}$ Ibidem, vol.II.pp. 50-51.

${ }^{271} \mathrm{O}$ feedback, discutido mais adiante. Cf. Ibidem, vol.I.pp.124-128.

272 Ibidem, vol. II.p.106.

${ }^{273}$ Ibidem, vol.II.p.196-197.

${ }^{274}$ Jean-Paul SARTRE.Op.Cit. p. 236.
} 
Iser amplia a idéia de preenchimento da percepção para a significação. O fruto desse processo que produz o sentido a partir daquilo que não está formulado diretamente na obra é o efeito estético, variante e indefinível ${ }^{275}$.

Da mesma forma a idéia do vazio da percepção pode ser ampliada para a significação no Conhece-te a ti mesmo. É possível de ser entendida como lacuna a justaposição entre palavra e imagem na poética, pois a integração das sentenças poéticas escritas e o objeto de tecido não se realiza até o fim (e haveria um "fim" para uma integração desse tipo?). Uma linguagem não se dissolve na outra, mantendo cada uma a sua atuação e heranças próprias e colocando para o leitor/espectador ${ }^{276}$ a tarefa de unilas num todo significante, isto é, formular a obra e formular-se a si próprio nesta concretização $^{277}$.

O conceito de preenchimento descreve como se dá o mecanismo de produção do sentido de uma obra literária. É o ato pelo qual o leitor, com seu conhecimento, imaginação e experiências preenche as lacunas da estrutura da obra - o não-dado - por meio da imagem ${ }^{278}$.

O leitor, ao se deparar com uma obra, tem diante de si uma dúplice realidade: uma situação não familiar ao seu universo - condição para o estímulo da leitura e da formulação; esta nova situação configura-se como uma estrutura que apresenta vazios 279

O preenchimento decorre da atividade imaginativa que capta e preenche o nãodado. O processo se dá a partir da estrutura da obra (cujo sentido tem caráter de imagem, não exprimível nem apreensível por palavras) que estimula uma seqüência de

\footnotetext{
${ }^{275}$ Wolfgang ISER. Op.Cit.,vol.I, p.16.

${ }^{276}$ Nesta teoria, voltada principalmente para a literatura, aquele que lê a obra é evidentemente chamado de leitor. O conceito de leitura, porém, é extensível para as artes plásticas - como fazem vários autores, Marin, por exemplo - tornando o papel de espectador análogo ao de leitor.

${ }^{277}$ Wolfgang ISER. Op.Cit.vol.II.p.92-93. Este conceito é o principal ponto de identificação entre a metáfora do oráculo e a recepção moderna. Será aprofundado no item Formula-te a ti mesmo.

${ }^{278}$ Ibidem, vol.I.p. 32.

${ }^{279}$ Ibidem, vol.I.p.79.
} 
imagens na consciência do leitor ao propor-lhe a já citada situação não familiar. Suas experiências continuam afetando o conteúdo dessas imagens, criando-se entre leitor e obra uma relação dialética num campo comum a ambos, no qual se formula o sentido da obra e que preenche o vazio de significado inicial ${ }^{280}$.

O não-dado funciona como um incentivo e um estímulo para o leitor ocupar as lacunas do sistema, via imaginação que sugere imagens e estabelece um significado para elas, originando-se assim um processo dialético dinâmico entre o mostrar e o encobrir, nas sucessivas tentativas do leitor completar as lacunas e ajustá-las ao todo ${ }^{281}$. Neste ponto, Iser colhe em Sartre a maneira pela qual surge no imaginário o significado dado pela totalidade da obra: "pois o dito parece ganhar sua significância só no momento em que remete ao que oculta" 282 .

\footnotetext{
${ }^{280}$ Ibidem, vol.I pp. 123-124 e vol.II,p.69.

${ }^{281}$ Ibidem, vol.I.p.92.

${ }^{282}$ Ibidem, vol.II, p. 106.
} 


\section{Interrelações entre palavra e imagem}

A dificuldade em transpor livremente a teoria do efeito estético para as artes plásticas é a de que o texto literário apóia-se nas constantes de uma língua de maneira mais fortemente codificada do que os códigos visuais da arte moderna. Mesmo assim, o próprio autor afirma que "o sentido de uma frase nunca é tão óbvio e redundante ao se pensar em efeito estético" ${ }^{283}$, permitindo uma aproximação com a ambigüidade das artes plásticas.

Se a matéria para a arte for a palavra ou a imagem, estamos de qualquer forma no campo da informação estética, a qual é uma mensagem ambígua e não unívoca, como afirma Eco. Há diferenças entre as duas matérias, mas também fortes semelhanças no modo de recepção destas duas naturezas que a arte ( e não apenas a contemporânea) se encarregou de integrar.

O próprio conceito de preenchimento é construído sobre as idéias de campo e Gestalt elaboradas por Arnheim. De forma resumida, a cada leitura forma-se uma nova Gestalt como uma reação em cadeia, no qual a Gestalt anterior ainda insuficiente para a formulação do sentido determina a seguinte, já num outro plano de apreensão, numa convergência que se dá dentro de um campo, fora da obra e do leitor ${ }^{284}$.

Para a construção dos procedimentos de leitura, Iser baseia-se várias vezes em conceitos elaborados por Gombrich para as artes plásticas ${ }^{285}$. Mesmo confrontando-se duas Gestalten que se dão uma no tempo e a outra no espaço, o processo de leitura de

\footnotetext{
${ }^{283}$ Pois o código estabelecido não necessariamente produz sentido (pense-se numa frase absurda); "por outro lado uma estrutura sem sentido pode ganhá-lo ao transitar e se ajustar a diversos conceitos". $O p$. Cit. vol.I, p.12.

${ }^{284}$ Ibidem, vol. I. pp.167-171.

${ }^{285}$ Iser utiliza-se do par conceitual esquema/correção: a teoria parte de experimentos perceptivos da teoria da Gestalt, na qual a representação não está separada das condições de sua recepção (o que é confirmado por Sartre). Nesse conceito, nosso esquema de percepção filtra e se modifica conforme a experiência percebida. Assim como o conceito de Iser de elemento estético, o esquema de Gombrich tem o caráter de vazio, não se encontra na obra, mas se mostra, se corrige e produz experiências na convergência de dois mundos ( $O$ Ato da Leitura,vol.I p. 167 e 170). Outra questão provinda de Gombrich é sobre o quanto e como as projeções do espectador complementam os vazios da obra, resultando numa interação entre texto e leitor (vol. II p.28-30).
} 
ambas, o preenchimento e seus ajustes e o feedback realizam-se na sucessão de eventos temporais $^{286}$.

O autor diferencia os atos de apreensão que traduzem um texto e um objeto estético. A principal e mais evidente diferença é que o texto, ao contrário do objeto estético, não se encontra todo diante da percepção. A apreensão de um texto como "objeto" se dá por fases consecutivas, dentro, e não diante deste, como é o caso do objeto $^{287}$.

Ainda é possível estabelecerem-se semelhanças entre as duas apreensões no fato de que o objeto estético, bi e tridimensional, não é captado em sua totalidade de uma só vez, mas também ele de forma consecutiva. Os objetos do Conhece-te a ti mesmo apresentam algo que podemos chamar de um texto curto, uma pequena sentença que, dentro do objeto no qual se apresenta, lhe superpõe uma apreensão explicitamente consecutiva.

Várias pontes entre os processos de leitura da literatura e das artes plásticas nos são dadas por Pareyson. Uma delas é onde o autor descreve o processo de leitura nas artes visuais, a outra é a atualização do conceito de beleza como efeito estético. Ambos os conceitos avizinham-se da teoria de Iser, ampliando-se a noção de texto e leitor deste último autor para as artes plásticas e para seu espectador.

Em sua teoria da formatividade, Pareyson o descreve o olhar como um processo temporal, através das interrogações do leitor, com comparações, correções e verificações sucessivas, as quais, se devidamente colocadas, criarão uma imagem que revelará a identidade da obra ${ }^{288}$, aproximando-se das idéias de feedback e preenchimento de Iser.

\footnotetext{
${ }^{286}$ Ibidem, vol. II.pp.28-30.

${ }^{287}$ Ibidem, vol. II. p.48.

${ }^{288}$ Luigi PAREYSON. Op.Cit., p. 227.
} 
Pareyson novamente encurta a distância entre a palavra e as artes plásticas ao tratar da matéria artística. As artes visuais são, necessariamente, "extrinsecação física", presença sensível onde o elemento físico é indispensável. Aparentemente desmaterializada, para o autor a palavra tem um aspecto que é físico: é som, e este é matéria para o poeta ${ }^{289}$.

No Conhece-te a ti mesmo a palavra é significante nos símbolos gráficos e também torna-se matéria, ao ser desenhada e bordada. Além disso, apresenta dentro da visão espacial e única de um trabalho de artes plásticas o tempo exigido para a percepção consecutiva de objetos tridimensionais e o tempo de leitura da palavra, o que proporciona analogias mais estreitas entre imagem e palavra e seus processos de apreensão, ampliando o conceito de leitura.

Esta poética, portanto, mostra-se como intertexto. Tessitura que assimila duas linguagens diferentes entre si (a verbal e a não-verbal), circula por entre ambas ${ }^{290} \mathrm{e}$ transfigura códigos já estabelecidos das artes plásticas, formando um novo texto.

Seu ponto de partida é absorver e transformar os códigos da gravura, do desenho, pintura e escultura; das práticas artesanais da costura e do bordado e de partes de sentenças filosóficas ou poéticas, obtendo um todo que resulta numa nova forma com seu próprio potencial estético. A relação do verbal com o não-verbal ocorre via justaposição e superposição de textos: a palavra bordada sobre a imagem, esta última suporte e comentário à primeira.

No Conhece-te a ti mesmo o elemento não-verbal é a materialização do verbal, distanciando-se de seus meios tradicionais de manifestação. O primeiro intensifica o aspecto de significante do segundo, sem perdas para os significados. Mimetiza-se a escrita no bordado ou no desenho, às vezes escondida por inteiro, às vezes por partes.

\footnotetext{
${ }^{289}$ Luigi PAREYSON. Op.Cit. ,p.153.

${ }^{290}$ Roland BARTHES. O Óbvio e O Obtuso.p. 139.
} 
O verbal tem o não-verbal como suporte para ser lido e como contraponto, para ser novamente lido. Ambos os textos dialogam entre si e, por sua vez, a totalidade que formam dialoga com o leitor. Num trabalho da série das Tautologias, Ne quid nimis, a quantidade e acúmulo de rosas e palavras contrariam a advertência apolínea do "Nada em demasia". 


\section{O processo de leitura}

A formulação do sentido de uma obra, isto é, o efeito estético a ser experimentado, é um processo descrito de forma análoga nos três autores, com algumas especificidades.São aqui apresentadas nos pontos em que se conformam com a estética do Conhece-te a ti mesmo.

Há consenso na construção de um processo de ida e volta entre obra e leitor que cria as representações e as corrige à medida que a leitura avança. Nesta relação dialética a formação de sentido final é comandada pela obra e pela experiência do leitor.

A formulação do sentido de uma obra, isto é, o efeito estético a ser experimentado tem validade "se a definição elaborada pelo sujeito supera-o como sujeito, afastando-se da subjetividade e alcançando independência" ${ }^{291}$.

Pareyson apresenta três fases de leitura cuja meta é a recuperação da poética inerente à obra, através da recodificação da proposta do artista, adotando-se o ritmo da

própria obra ${ }^{292}$.O autor recusa tanto leituras que tentem evocar impessoalmente a obra, deixando de lado a contribuição do leitor, quanto as que traduzem a obra como atividade pessoal do leitor, que causem tantas reelaborações diversas quanto leitores houver ${ }^{293}$.

A seqüência das fases se dá pelos conceitos de execução, de interpretação e a avaliação. A noção de execução significa o ato temporal da leitura. Neste momento reconstrói-se a realidade da obra, admitindo-se uma multiplicidade de execuções que,

\footnotetext{
${ }^{291}$ Wolfgang ISER. Op.Cit. vol.I, p.33.

${ }^{292}$ Mônica TAVARES. Op.Cit.,p.39-40.

${ }^{293}$ Luigi PAREYSON. Op. Cit. p.204.
} 
porém, despertem a obra para sua própria vida. A obra apresenta-se como realidade completa a ser executada ${ }^{294}$.

A execução é o critério de penetração na obra. Uma certa dose necessária de contemplação que não anula o leitor perante a obra, mas é entendida como extrema receptividade e atividade durante a qual "se deixa o objeto ser" 295.

"A obra exige execução precisamente porque está acabada e perfeita". Em sua completude já reside a idéia da execução, o que não contraria a idéia do preenchimento de Iser, "pois só o que é inteiro e completo permite significar" ${ }^{296}$. Neste caso o não-dito faz parte da completude que se abre e convida à interpretação.

Pareyson extrai a palavra "execução" da linguagem musical, concedendo ao leitor o papel de intérprete, o que coincide com a imagem da obra como partitura, nas palavras de Iser $^{297}$.

A interpretação, a segunda etapa, dentre os vários possíveis pontos de vista, procura aquele através do qual se dará o olhar e a leitura. É a fase que melhor descreve a relação pergunta e resposta oraculares.

Exerce uma função dialética intensa, consciente e controlada que interroga a obra, criando com ela um diálogo "de perguntas que se souberam fazer e de respostas que se souberam captar" na busca do segredo - a resposta do oráculo, neste caso encerrado na obra ${ }^{298}$.

\footnotetext{
${ }^{294}$ Ibidem, . p. 218-220.

${ }^{295}$ Seria a contemplação que procura fixar seu objeto "na sua verdadeira e autônoma natureza" sem alterar suas características. Ibidem. . p.206.

${ }^{296}$ Ibidem, p.219-220.

${ }^{297}$ Wolfgang ISER. Op.Cit. vol.II, p.11.

${ }^{298}$ Luigi PAREYSON. Ibidem, p.207.
} 
O autor mostra este processo como colóquio, no qual "a obra fala a quem sabe interrogá-la melhor e a quem se põe em condições de saber escutar sua voz: ela espera ser interrogada de um certo modo para responder revelando-se" 299.

"A obra abre-se somente àquele que consegue captá-la" ${ }^{300}$, o que sugere a mesma natureza da mensagem plurívoca de um oráculo.

A avaliação, enfim, supera os dois tipos ainda insuficientes de leitura anteriormente descritos: é uma afinidade conquistada que pretende reevocar a obra por meio da imaginação e do conhecimento do leitor ${ }^{301}$.

As etapas do leitor de Eco confirmam os consensos já apontados. O instrumento de leitura do receptor é a adequação entre suas "possibilidades fruitivas e as intenções implicitamente manifestadas pelo autor", quando da formação da obra ${ }^{302}$.

O autor elenca alguns "protocolos de leitura" válidos: o reconhecimento da liberdade da obra, a recusa do unívoco e de nexos causais entre os elementos, a abertura a descobertas imprevisíveis, procedimentos que elaboram e modificam continuamente a experiência do leitor ${ }^{303}$.

O leitor desfruta da obra, perseguindo livremente as associações que o conjunto de estímulos lhe sugere, mas julgando-a ao mesmo tempo, refletindo sobre seu gozo e qualificando-a na sua experiência. Desta forma, estabelece-se a relação dialética ${ }^{304}$. O segundo momento é a comprovação de suas hipóteses na obra, a base sobre a qual o leitor controla sua experiência. É no modo como a obra foi feita que se dará o

\footnotetext{
299 Ibidem,p.235.

${ }^{300}$ Mônica TAVARES,Op.Cit., p.40.

${ }^{301}$ Luigi PAREYSON. Ibidem, p.236-237.

${ }^{302}$ Umberto ECO. Op.Cit., p. 170.

${ }^{303}$ Ibidem. p.160 para os protocolos de leitura e p.142 para o que o autor chama de "sistema de assunções", que seria o "modelo cultural do homem ocidental".

${ }^{304}$ Ibidem. p. 170.
} 
julgamento sobre os meios usados, os resultados obtidos, as intenções adaptadas, as pretensões não realizadas ${ }^{305}$.

A essência dos procedimentos descritos resume-se na idéia de Iser de feedback: um mecanismo auto-regulador através do qual se criam e se sucedem as representações criadas pelo leitor.

O leitor recebe os significantes durante a leitura e realiza ao mesmo tempo um feedback constante de informações sobre o efeito produzido, inserindo no processo suas próprias representações (um processo de vai-e-volta que enriquece a leitura à medida que se desloca da obra para o leitor e de novo deste para a obra). Conforme se desenrola o feedback, a relação obra-leitor estabiliza-se, ajustando-se a leitura ${ }^{306}$.

O feedback é o meio através do qual se realiza o processo de formulação do leitor. Neste processo a leitura não aditiva, mero reconhecimento ou identificação do que já se sabe, ao constituir-se efeito experimentado e atualizado pelo leitor, torna-se experiência e "reestrutura o que somos" ${ }^{307}$.

A formulação é descrita na literatura, mas em sua síntese podemos encontrar identificação com as artes visuais. Os significantes da obra denotam algo, mas apresentam mais: instruções para que o leitor construa um significado que vá além da denotação. Esta denotação é imagem, é icônica e, por meio do que ela denota, o leitor passa a imaginar aquilo que ela exclui, isto é, o não-dado. As "instruções" designam as condições pelas quais a imaginação do leitor pode atuar. Ao cumpri-las, o leitor gera conseqüências e constrói um significado ${ }^{308}$. O significado construído torna-se significante para o leitor em seu próprio repertório, produzindo o objeto imaginário, que constitui o sentido da obra ${ }^{309}$.

\footnotetext{
305 Ibidem, p. 170.

${ }^{306}$ Wolfgang ISER. Op.Cit. vol.II, p.124-125.

${ }^{307}$ Ibidem,vol. II, p.50-51.

${ }^{308}$ Ibidem, vol.I. pp.122-123.

${ }^{309}$ Ibidem, vol. II, p.122-123.
} 


\section{Conhece-te a ti mesmo como Formula-te a ti mesmo}

A recepção proposta para a estética do Conhece-te a ti mesmo é a de uma leitura que, como sugerido pelo título, pretende atingir a consciência do leitor como formulação e descoberta de aspectos não só da obra mas também sobre si próprio por meio do efeito estético que, podendo apenas ser proporcionado pela arte, assume uma formulação original e nova para cada obra em particular e reformulando por sua vez o repertório e a consciência do leitor.

A partir do pensamento de Iser é possível ampliar o alcance das definições de leitura e texto para a recepção de uma obra de arte e dos trabalhos do Conhece-te a ti mesmo:

"A constituição de sentido que acontece na leitura, portanto, não só significa que criamos o horizonte de sentido, tal como implicado pelos aspectos do texto [obra]; ademais, a formulação do nãoformulado abarca a possibilidade de nos formularmos e de descobrir o que até esse momento parecia subtrair-se à nossa consciência. Neste sentido, a literatura [e podemos ampliar para a arte em geral] oferece a oportunidade de formularmo-nos a nós mesmos, formulando o não-dito" ${ }^{310}$.

${ }^{310}$ Ibidem, vol.II, p.92-93. 
Terceiro capítulo

\section{O Nascimento da Tragédia}

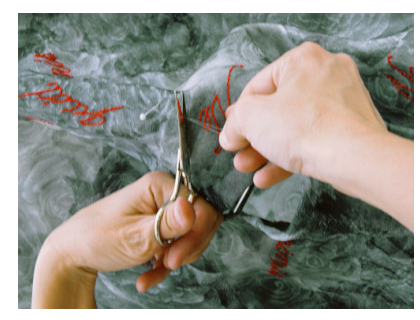




\section{O Nascimento da Tragédia}

"A convicção sobre a unidade de tudo que vive garante que houve certa vez um imenso vivente, do qual somos parte." 311

Friedrich Nietzsche

Logo após o momento da vinculação do trabalho artístico com a metáfora do oráculo, da escolha da sentença délfica e da opção pela beleza aparente nesta poética houve o encontro com a obra de Nietzsche e as inevitáveis associações.

No decorrer da leitura e do desenvolvimento do Conhece-te a ti mesmo surgiram tanto identificações quanto contradições. Este capítulo trata destas relações, nas quais o trabalho artístico não é ilustração das concepções de Nietzsche nem se inscreve na estética daquela época.

Há dois temas essenciais de discussão: a afinidade da poética com a concepção de beleza aparente e a superação do antagonismo entre a sentença socrática que intitula este trabalho com o direcionamento estético da obra dado por seu autor.

Para se atingir esses objetivos será necessário apresentar a origem e as características de $O$ Nascimento da Tragédia, descrever o contexto social, estético e cultural nos quais nasce e a relação destes com o pensamento de Nietzsche.

${ }^{311}$ Friederich NIETZSCHE. Apud Márcio BENCHIMOL.Apolo e Dionísio.p.23. 
A essência da obra está figurada na relação de polaridade e complementaridade entre as figuras de dois deuses olímpicos: Apolo e Dioniso. Para a compreensão plena das implicações simbólicas dessa imagem na arte será necessário aproximar-se primeiro dos mitos gregos, depois da interpretação nietzscheana dada a ambos e, por fim, da solução do livro. 


\section{A origem de $O$ Nascimento da Tragédia}

Esta obra origina-se de duas conferências proferidas por Nietzsche no ano de $1870^{312}$. A primeira, O Drama Musical Grego, apresenta a tese do surgimento da tragédia grega dos rituais dionisíacos. O excesso e êxtase dessas festividades teriam originado a tragédia no palco, que tem sua estrutura descrita ${ }^{313}$.

Na segunda conferência, Sócrates e a Tragédia,o filósofo incide sobre o teatro socrático. Ali desenvolve uma crítica à linguagem, à lógica e à consciência representadas pelo Logos que vence o Pathos na dialética de Sócrates ${ }^{314}$.

Evidencia-se já nesse momento a origem da polaridade que mais tarde se tornaria a chave encontrada por Nietzsche para a compreensão da cultura clássica e da cultura em geral: o par de opostos complementares Apolo e Dioniso ${ }^{315}$.

Na Tentativa de Autocrítica ${ }^{316}$ que sucede $O$ Nascimento da Tragédia, catorze anos após a publicação, lê-se o relato de Nietzsche sobre a "voz estranha" com a qual já se manifestava ainda imprecisamente o princípio dionisíaco, uma voz portadora de necessidades ainda inominadas, com perguntas, experiências e coisas ocultas, interpretadas pelo filósofo como aspecto desconhecido do mundo grego ${ }^{317}$.

\footnotetext{
${ }^{312}$ O Nascimento da tragédia foi escrito em 1871 e publicado no ano seguinte.

${ }^{313}$ Rüdiger SAFRANSKI.Nietzsche.p.52.

${ }^{314}$ Ibidem, p.54.

${ }^{315}$ Ibidem, p.56.

${ }^{316} \mathrm{Em} 1886$ Nietzsche revê a obra e as opções feitas na época. Interpreta seu contato com a filosofia de Schopenhauer e a amizade com Wagner como um extravio dos seus instintos.Cf. Sandro Kobol FORNAZARI. Sobre o Suposto autor da Autobiografia de Nietzsche.p.100. Nietzsche reconsidera o Nascimento da Tragédia classificando-o como um livro "estranho", "difícil", problemático e até mesmo "impossível", no que concerne à forma do conteúdo e à forma de expressão, cuja causa principal seria a de ter projetado em Wagner uma idéia schopenhaueriana da tragédia vista como renúncia e abdicação. Cf. Roberto MACHADO. Arte e Filosofia no Zaratustra de Nietzsche. In: Adauto NOVAES. Artepensamento.p.139.

${ }^{317}$ Friedrich NIETZSCHE. O Nascimento da Tragédia. p.16-21.
} 
A idéia da oposição do par Apolo-Dioniso nasce sob a ótica da superação da metafísica que cinde o mundo entre o inteligível e o sensível ${ }^{318}$ e da História. Um diante do outro, deveriam iluminar-se e compreender-se mutuamente ${ }^{319}$.

${ }^{318}$ Richard BEARDSWORTH. Nietzsche. p.26.

${ }^{319}$ Márcio BENCHIMOL. Apolo e Dionísio.p.23. 


\section{Contexto filosófico, social e estético}

A imagem construída da Grécia na época do Nascimento da Tragédia era aquela concebida por Winckelmann: uma humanidade branda, simples, nobre. A Grécia encarnava a "unidade do bom, belo e verdadeiro" platônico e socrático ${ }^{320}$. A sociedade da época considerava a antigüidade ilustrativa, retórica ${ }^{321}$.

Nietzsche vê a cultura de sua época fraturada, com conseqüências que confundem o homem moderno, que desconfia de seus antigos apoios no conhecimento. O homem teria então adotado três graus de ilusão que o ajudariam a suportar a existência: o prazer socrático do conhecer; o véu de beleza da arte e o consolo metafísico da vida eterna ${ }^{322}$.

O papel da arte no contexto social pós-1850, quando se fortalece "uma cultura do trabalho e do utilitarismo que se encanta com o trabalho" ${ }^{323}$, é um papel suavizador, limitado e não-fundamental. O burguês que vê a arte como bela, mas secundária, tornase para Nietzsche o "filisteu da cultura" ${ }^{324}$. Em outros escritos do autor encontra-se o homem moderno descrito como alguém "com os nervos fatigados". O artista moderno estaria na visão do filósofo buscando e produzindo efeitos para um público formado por "exaustos e distraídos" 325 .

Nietzsche aponta em sua época o problema do "epigonismo": o excesso de consciência histórica do homem de seu tempo, que o impede de produzir a novidade e busca as formas de sua arte no passado, como máscaras ${ }^{326}$.

\footnotetext{
${ }^{320}$ Rüdiger SAFRANSKI Op.Cit.p.129.

${ }^{321}$ Giorgio COLLI. Scritti su Nietzsche, $2^{\mathrm{a}}$ ed. p. 26.

${ }^{322}$ Friedrich NIETZSCHE. Op. Cit.p.108.

${ }^{323}$ Rüdiger SAFRANSKI. Op.Cit.p. 100.

${ }^{324}$ Rüdiger SAFRANSKI. Op. Cit. p.101.

325 Jean LACOSTE. A Filosofia da Arte.p.74.

${ }^{326}$ Gianni VATTIMO. O Fim da Modernidade.p. 170.
} 
A idéia do que deveria de fato ser a cultura é concebida por Nietzsche como sendo parte de um processo vital, não o resultado de uma convenção, mas uma entidade enraizada no natural e no orgânico, refletindo e ao mesmo tempo engendrando o povo. Este último visto pelo filósofo como entidade também orgânica ${ }^{327}$.

O traço distintivo de uma cultura saudável seria então o equilíbrio entre os elementos apolíneo e dionisíaco, os "instintos artísticos da natureza". O pendor excessivo para apenas um dos dois lados produziria numa cultura o sentimento do absurdo, no caso de Dioniso, ou do superficial ${ }^{328}$.

${ }^{327}$ Márcio BENCHIMOL. Op. Cit.p.105.

${ }^{328}$ Ibidem.p.116. 


\section{Características da obra}

O mundo grego torna-se o ponto de partida para a crítica da modernidade. Nietzsche utiliza-se da imagem do espelho:

"Quando falamos dos gregos, falamos também involuntariamente de hoje e de ontem: sua história, universalmente conhecida é um espelho claro que reflete sempre algo mais do que se encontra no próprio espelho" ${ }^{329}$.

A obra revela uma concepção de arte construída a partir do horizonte retrospectivo da vida e arte gregas, essenciais à vida, dirigindo-se como crítica à modernidade social e artística contemporâneas ao filósofo ${ }^{330}$.

Em O Nascimento da Tragédia, ele a trata como algo vivente, não historicizável, falando também a quem não se interessava por ela ${ }^{331}$.O assunto da obra não é exatamente a antigüidade, mas, segundo Colli, os instrumentos de liberação para o modo como Nietzsche percebia a cultura e a sociedade de seu tempo: acorrentadoras. Libertar a natureza humana seria penetrar na ebriedade e no sonho, pois no mundo circundante não estaria a verdadeira vida ${ }^{332}$. Ebriedade e sonho: Dioniso e Apolo.

Estas primeiras contraposições - podemos vê-las como fissuras -- entre antigüidade e modernidade, entre condicionamentos culturais e pulsões naturais encontram confirmação também no modo como Nietzsche via seu contexto filosófico, dentro do qual nasce a obra com mais uma atribuição: superar a cisão metafísica que privilegia o inteligível ao sensível, associando apenas o primeiro à verdade. Mais uma vez a fonte que pode vencer a fissura está na Grécia onde, antes da metafísica, a arte justificava a vida, era a doadora das formas, produzia as condições salvadoras do homem dentro das quais a humanidade poderia viver ${ }^{333}$.

\footnotetext{
${ }^{329}$ Friedrich NIETZSCHE. Apud Marc JIMENEZ. O Que É Estética?. p.242.

${ }^{330}$ Marc JIMENEZ. O que É Estética?p.242.

${ }^{331}$ Giorgio COLLI. Scritti su Nietzsche. p.26.

332 Ibidem.p. 19.

${ }^{333}$ Richard BEARDSWORTH.Op. Cit. p.26-40.
} 
Eis $O$ Nascimento da Tragédia: livro cujo impulso inicial foi o de tratar da tragédia musicalmente ao "unir música com filologia" ${ }^{334}$. Dedicado a Richard Wagner, associando sua obra a um despertar dionisíaco da música e da própria Alemanha ${ }^{335}$, ainda escrito sob a influência da idéia da redenção pela arte da filosofia de Schopenhauer ${ }^{336}$ e essencialmente uma obra que critica a racionalidade socráticoplatônica persistente na modernidade ${ }^{337}$. A alternativa nietzscheana: a polaridade Apolo-Dioniso ${ }^{338}$.

As figuras de Apolo e Dioniso são apresentadas como duplicidades contrapostas que, unidas, geram a tragédia ática. Nietzsche detém-se e aprofunda-se em Dioniso. Este possui um particular tipo de saber, imanente à vida, visceral, que dela não se distancia. O saber dionisíaco reconcilia homem e natureza. Neste contexto, a imitação da natureza pela arte ganharia novo sentido: encarnando as suas pulsões na criação artística. ${ }^{339}$.

\footnotetext{
${ }^{334}$ Rüdiger SAFRANSKI. Op. Cit. p.51.

${ }^{335}$ Jean LACOSTE.A Filosofia da Arte.p.67.

${ }^{336}$ Rüdiger SAFRANSKI.Op. Cit. p.37/38.

${ }^{337}$ A publicação dessa obra trouxe várias conseqüências para Nietzsche. Por um lado recebeu o reconhecimento de Wagner. Por outro o mundo acadêmico critica a publicação e afasta-se do filósofo. Nietzsche chega a adoecer com a repercussão negativa embora não tenha abandonado a crítica ao saber. Cf. Rüdiger SAFRANSKI. Op. Cit p.73.

${ }^{338}$ Roberto MACHADO.Arte e Filosofia no Zaratustra de Nietzsche.In: Adauto NOVAES (org.). Artepensamento.p.137

${ }^{339}$ José Luiz FURTADO. A Essência da Vida na Filosofia da Arte em O Nascimento da Tragédia..p.10.
} 


\section{Apolo na mitologia grega}

Apolo representa a arte do figurador plástico (Bildner), originária do mundo dos sonhos e da aparência. É ao mesmo tempo o plasmador da beleza plástica, que encobre a verdadeira essência do homem por meio da "ilusão magnífica" operada pela arte. Apolo deste modo delimita a fronteira do indivíduo, dá-lhe a justa medida para que consiga viver ${ }^{340}$.

É o deus da beleza, o mais belo, porque ekphanèstaton, "o mais manifesto", que torna manifestas todas as coisas. Ele é a luz que desenha os contornos e os limites daquilo que é" 341 .

Filho de Zeus e Leto e gêmeo de Ártemis, Apolo nasceu na ilha de Delos, onde sua mãe se refugia para escapar da ira de Hera. Mais tarde identificado com Helios, o Deus-sol que dirige sua carruagem pelos céus ${ }^{342}$.

Zeus, após ter cortado ao meio o orgulhoso ser andrógino do qual provieram homem e mulher, quis que fosse Apolo aquele que mostrasse a secção à metade restante, para que, através dessa contemplação, o homem se tornasse mais moderado. É com Apolo que surge, portanto, a consciência do limite humano em relação aos deuses ${ }^{343}$. Ele encarna o ideal de sabedoria grego. Realiza o equilíbrio e a harmonia dos desejos orientando as pulsões humanas para uma espiritualização progressiva graças ao desenvolvimento do autoconhecimento por meio da consciência ${ }^{344}$.

Platão, em A República, ao enunciar os deveres do verdadeiro legislador, aconselha que se pergunte a Apolo, estabelecido no umbigo do mundo - o oráculo de Delfos -- para guiar o gênero humano, para ditar as mais importantes e belas leis

\footnotetext{
${ }^{340}$ Friedrich NIETZSCHE. Op.Cit.p.39-40.

${ }^{341}$ Vincenzo VITIELLO. Deserto Ethos Abbandono. In: DERRIDA e VATTIMO (org.) La religione pp.147-148.

342 James HALL, Dictionary of Subjects \& Symbols in Art, p.67.

${ }^{343}$ Esta concepção encontra-se no Simpósio de Platão. Cf. Vincenzo VITIELLO.Op. Cit.pp.147-148.

${ }^{344}$ J. CHEVALIER. Dicionário de Simbolos,pp.66-67.
} 
primordiais que regulam os cultos religiosos, por ser este intérprete tradicional da religião, algo que os homens desconhecem e à qual se submetem ${ }^{345}$.

\section{É o principal deus cultuado em Delfos:}

"Apolo 'febo' é o 'puro', sua visão não está contaminada pelo elemento acidental dos acontecimentos. Apolo não prevê, vê. Conhece o ordenamento necessário do mundo e vê o ordenar-se de todos os tempos" ${ }^{346}$.

A reunião que Apolo realiza em si da beleza com a medida e a ordem remonta à luta e à vitória parcial de Zeus contra as divindades noturnas associadas ao caos ${ }^{347}$. Zeus estabelece depois usa as próprias leis dos limites intransponíveis fundamentadas sobre a noção de "medida" ${ }^{348}$.

Materializa-se a idéia contida neste mito no oráculo de Apolo:

"junto com seu filho Apolo, ele guarda tais medidas (metra) segundo normas codificadas nas inscrições colocadas nos muros externos do templo de Delfos. 'O (homem) mais justo é o mais belo', 'observa o limite', 'odeia a hybris' e 'qualquer coisa em excesso'. Essas duas divindades lutam contra a transposição insolente destas fronteiras indo em direção da desmedida e da desordem" ${ }^{349}$.

Apolo simboliza a vitória sobre a violência, o autodomínio no entusiasmo, a espiritualização, a aliança entre paixão e razão, pois sua sabedoria é conquistada e não herdada ${ }^{350}$.

\footnotetext{
${ }^{345}$ Ibidem. pp.66-67.

${ }^{346}$ Vincenzo VITIELLO. Op. Cit pp.147-148.

${ }^{347}$ Lembremos que uma das versões do nascimento de Dioniso coloca-o como filho de Perséfone, justamente a deusa subterrânea do mundo dos mortos. Cf. Pierre LAVEDAN. Dictionnaire Illustré de lla Mythologie et des Antoquités Grecques et Romaines. p.340.

${ }^{348}$ Remo BODEI. As formas da Beleza. p.23-24.

${ }^{349}$ Embora seja em seguida tolerada a reintrodução periódica do caos na forma dos cultos dionisíacos. Cf. Remo BODEI. Op. Cit. p.23-24.Esta relação de convivência entre caos dionisíaco e ordem apolínea é retomada por Nietzsche na idéia da necessária complementaridade entre os dois princípios.

${ }^{350}$ J.CHEVALIER Op. Cit .pp.66-67.
} 


\section{Dioniso na mitologia grega}

É o deus nascido duas vezes, cuja característica é ser múltiplo: o Delirante, o Murmurante, o Fremente. Dioniso teve duplo nascimento. Ao ser retirado do ventre de Sêmele, acaba sua maturação na coxa do pai, Zeus - o que remete ao esquema clássico da iniciação: nascimento, morte e renascimento ${ }^{351}$.Deus da vegetação, da vinha, do vinho, dos frutos, da renovação sazonal, é aquele que distribui a alegria em profusão ${ }^{352}$.

Nas formas de seu culto celebram-se a libertação, a catarse, a supressão das proibições e dos tabus . Também libertador dos infernos, de lá resgatou Perséfone, sua mãe como Dioniso Zagreu ${ }^{353}$.

Através do excesso, do irromper do inconsciente, seu culto testemunha um esforço violento para romper a barreira que separa o humano do divino, na busca de algo sobre-humano ${ }^{354}$.

\footnotetext{
${ }^{351}$ Pierre LAVEDAN. Op. Cit p.333-334.

${ }^{352}$ Segundo Hesíodo, poeta grego autor da Teogonia, obra na qual descreve a origem do mundo e a genealogia dos deuses (Hesíodo viveu no século VIII a. C.).Ibidem. p.333-334.

${ }^{353}$ As festas dionisíacas eram rituais com até seis dias de duração, celebradas em vários meses do ano no mundo helênico. Estenderam-se por toda a Grécia, dentro e fora de Atenas, até a Ásia Menor, Sicília, Roma e Etrúria.Essencialmente eram celebrações coletivas, que assumiam a forma de cortejo composto de coros e danças, que culminava no delírio absoluto pelas ruas. Era celebrada em Delfos um dos dois tipos de festas, a orgiástica, na qual Dioniso era invocado pelas Bacantes. Cf. Pierre LAVEDAN. $O p$. Cit.p.333-334.

${ }^{354}$ Ibidem. p.333-334.
} 


\section{Apolo e Dioniso em $O$ Nascimento da Tragédia}

Apolo é o deus dos poderes configuradores e deus divinatório, nele os gregos expressam a "alegre necessidade da experiência onírica". Sob o nome de "resplendente", divindade da luz, reina sobre "a bela aparência do mundo interior da fantasia". As propriedades deste mundo são a verdade superior e a perfeição desse estado, a consciência da natureza sanadora e reparadora do sonho, qualidades análogas às das artes. Apolo é também a limitação, a sábia tranqüilidade que limita a imagem onírica ao seu reino, para que esta não se torne patológica e seja confundida com a realidade ${ }^{355}$. Apolo é o endeusamento da individuação ${ }^{356}$ e da observação das fronteiras do indivíduo: a medida, a qual, para poder ser observada necessita do autoconhecimento, como advertem as sentenças inscritas em Delfos ${ }^{357}$.

Apolo também apresenta sua bipolaridade interior. Se nele se realiza a libertação através da aparência, o próprio deus mostra ao homem a necessidade de sua passagem pelo mundo do tormento, para que uma libertação possa ocorrer. Apolo apresenta, portanto, um caminho tortuoso e sofrido para o autoconhecimento e a conquista da condição de indivíduo.

É nos limites do indivíduo que se satisfaz a necessidade de beleza na contemplação de imagens ( pois contemplar é uma atividade que não se compartilha). É, portanto, apolíneo o território da arte plástica, a "linguagem das imagens" 358 por excelência e apolíneo também é o pensamento individual que é capaz de apreender a vida como conceito ${ }^{359}$.

\footnotetext{
${ }^{355}$ Friedrich NIETZSCHE. Op. Cit. p.29.

356 Nietzsche atribui a Apolo a característica de ser o deus do principium individuationis. Na obra do filósofo essa noção existente desde a filosofia escolástica e herdada diretamente da influência sofrida por Schopenhauer apresenta-se como "aquilo que possibilita que a unidade primordial da vida se manifeste por meio da multiplicidade dos viventes individuais, sendo, portanto, idêntico ao próprio impulso apolíneo (...)" Cf. Márcio BENCHIMOL. Op. Cit. .p.58. Sob a ótica schopenhaueriana seria o homem individual que preserva a consciência de si enquanto indivíduo na multiplicidade e no caos do mundo. Cf. Friedrich NIETZSCHE. Op. Cit.p.30.

357 Ibidem. p.40.

358 Ibidem. p. 102.

${ }^{359}$ Ibidem p. 127.
} 
Nietzsche identifica-se com Dioniso, que assume no decorrer da vida do filósofo significados particulares. Dioniso Zagreu, deus dos mistérios órficos gregos, era o deus-símbolo da vida eterna no mundo dos viventes, conhecido também por outro nome mais tarde usado para Jesus Cristo: Soter, salvador ${ }^{360}$.

Dioniso é o herói trágico da tragédia grega. Nesta é Dioniso sofredor que, criança, foi despedaçado e devorado pelos Titãs. Foi então engolido por Zeus e renovase como Dioniso Zagreu. O despedaçamento é uma transformação em elementos da natureza e comunhão com esta, espelha a aniquilação ${ }^{361}$.

Próximo de perder a razão, na última linha de Ecce Homo, Nietzsche escreve: "fui compreendido? Dioniso contra o Crucificado". Postura que confirma, pela escolha da figura do deus, suas propostas de transcendência e transvaloração e assume as qualidades do mito para si ${ }^{362}$.

Para Nietzsche, Dioniso e Zaratustra são dois momentos -- criações que se confundem com as obras -- nos quais o filósofo tenta encarnar um tipo sobre-humano que possua a força de destruição de uma humanidade decadente ${ }^{363}$.

Na Tentativa de Autocrítica Nietzsche relata que ouviu Dioniso primeiro como "uma voz estranha", com necessidades ainda inominadas, com perguntas, experiências e coisas ocultas; uma "nova alma", um aspecto desconhecido do mudo grego. Um mistério que persiste para o filósofo mesmo catorze anos após ter completado o Nascimento da Tragédia ${ }^{364}$.

\footnotetext{
${ }^{360}$ Paulo César de SOUZA, Ecce Homo (posfácio), p.138.

${ }^{361}$ Friedrich NIETZSCHE. Op. Cit. pp.69-70.

${ }^{362}$ Paulo César de SOUZA. Op. Cit p.138. A transvaloração contrapõe-se naquele contexto aos valores cristãos, questão marginal à presente discussão.

${ }^{363}$ Sandro Kobol FORNAZARI. Sobre o Suposto Autor da Autobiografia de Nietzsche. p.110.

${ }^{364}$ Friedrich NIETZSCHE. Op. Cit. pp.16-21.
} 
A essência do dionisíaco ${ }^{365}$ é construída por uma analogia com a embriaguez, a intensificação do subjetivo que chega ao auto-esquecimento. É a reconciliação entre homem e natureza, entre homem e homem, na qual cada um se torna um só com o seu próximo. Também significa a regressão da fala (logo, do pensamento conceitual). Em seu lugar toma importância o corpo, a dança, o encantamento, a música: "o homem não é mais artista, tornou-se obra de arte: a força artística de toda a natureza" ${ }^{366}$.

Dioniso é aquele que rasga o véu de Maia ${ }^{367}$. Rompe dessa forma a individuação apolínea e desvela "o cerne mais íntimo das coisas". A metáfora do véu e de seu rasgamento significam para Nietzsche a expressão direta da vida sem a intermediação da imagem ${ }^{368}$, ação perpetrada pelas forças que Dioniso representa: o inaudito, o irracional.

\footnotetext{
365 O termo "dionisíaco" nem sempre é tratado por Nietzsche de forma rigorosa, mas significa essencialmente o "uno primordial", "O Ser abrangente em última análise incomprrensível". Cf. Rüdiger SAFRANSKI. Op. Cit.p.69.

${ }^{366}$ Friedrich NIETZSCHE. Op. Cit. pp.30-31.

${ }^{367}$ Maia é a ninfa que personifica o despertar da natureza na primavera, projeção da energia vital, simboliza a exteriorização do eu. Cf. J. CHEVALIER. Op. Cit.. p.650. O véu de Maia é uma imagem proveniente da filosofia indiana, usada por Schopenhauer. No pensamento hindu o véu da deusa significa a aparência ilusória que vela a realidade e leva o homem a ignorá-la. Cf. BIRAGHI. Dicionário de Filosofia.p.215.

${ }^{368}$ Friedrich NIETZSCHE. Op. Cit p.31.
} 


\section{Polaridade e complementaridade de Apolo e Dioniso}

Apolo - a medida, a consciência, o indivíduo, o sonho. Dioniso - o desmedido, o universal, a "realidade inebriante", a festa. Apolo oculta o cerne da vida, aniquilador para o homem. Dioniso nele mergulha. Esta aparente oposição se traduz no Nascimento da Tragédia em complementaridade.

Em nenhum momento Nietzsche alude a qualquer tipo de predominância ou escolha de um dos dois princípios. A sobrevivência de ambos está na conciliação proposta no final da obra, onde os dois impulsos artísticos "são obrigados a desdobrar suas forças em rigorosa proporção recíproca" ${ }^{369}$ como se se erguessem impetuosamente da natureza os poderes dionisíacos e descessem dos céus os de Apolo. Juntos produzirão "soberbos efeitos de beleza" ${ }^{370}$.

Há um limite para a presença das duas polaridades no homem. Convivem em igualdade de forças.O preço do desequilíbrio seria fechar-se ao criativo e ao incomensurável da vida, no caso da dominância apolínea, ou mergulhar na escuridão, chegando ao aniquilamento se preponderar Dioniso ${ }^{371}$.

Segundo Langer a polaridade de princípios entre os quais é buscado um ponto de equilíbrio perfeito é um modelo há muito estabelecido no pensamento filosófico. Por meio dos dois deuses, apresentados como extremos que se contrabalançam mutuamente, Nietzsche apresentaria os aspectos extremos da obra de arte dividida entre o puro sentimento e a pura forma:

"Esse tratamento de uma antítese básica na teoria da arte absorveu toda uma classe de 'polaridades' relacionadas: emoção-razão, liberdade-restrição, personalidade-tradição, instinto-intelecto $(\ldots)^{372}$.

\footnotetext{
${ }^{369}$ Ibidem. pp. 143.

${ }^{370}$ Ibidem.,pp. 144.

${ }^{371}$ Rüdiger SAFRANSKI. Op. Cit .p. 71.

${ }^{372}$ Susanne LANGER. Sentimento e Forma.p.18.
} 
Enfim, ainda nas palavras de Langer, entre ethos e pathos. A autora esclarece que tal dialética não explica a natureza da arte, mas apenas inicia a indagação filosófica 373

Para Nietzsche há de fato uma "duplicidade" e uma "contraposição" entre o apolíneo (a arte do figurador plástico, Bildner) e o dionisíaco (a arte não figurada da música, unbildlichen), vê ambas caminhando lado a lado em luta contínua, a incitaremse mutuamente, com reconciliações periódicas ${ }^{374}$.

O emparelhamento de ambas é resolvido de duas formas. Primeiro pela tragédia ática (a obra de arte), fruto da união dos dois princípios. Depois pelo artista, o mediador das duas forças, que age sob a dupla influência do sonho e de "um sentimento místico de unidade" com a natureza ${ }^{375}$.

Nas predições do oráculo de Apolo em Delfos encontram-se novamente os dois princípios. Sob a beleza e o comedimento, por baixo da sabedoria e da justa medida revelam-se o sofrimento e o conhecimento revelado pelo dionisíaco ${ }^{376}$ transe da Pítia, o instrumento da revelação: "E vede! Apolo não podia viver sem Dionísio" 377.

O dionisíaco é o substrato do mundo, o fundamento da existência, mas só consegue penetrar na consciência do indivíduo pela força transfiguradora apolínea, daí o eterno e necessário alternar-se ${ }^{378}$.

Nietzsche recusa-se derivar as artes de um princípio único. As possibilidades de contato com a arte são aparentemente antagônicas, mas interdependentes. Enquanto Apolo é contemplar - a imagem --, Dioniso é sentir - a música ${ }^{379}$. Dois mundos que

\footnotetext{
373 Ibidem pp. $18-20$.

${ }^{374}$ Friedrich NIETZSCHE, Op. Cit. p.27.

375 Ibidem. pp.27-32.

${ }^{376}$ Nietzsche postula para Dioniso um tipo específico de conhecimento: a sabedoria dionisíaca. Não é, portanto, inadequado usar essas duas palavras ao se reportar a Dioniso. Basta contextualizá-las num sentido onde o real ultrapassa o racional. Cf. Rüdiger SAFRANSKI. Op. Cit. p.55.

${ }^{377}$ Friedrich NIETZSCHE. Op. Cit. pp.40-41.

${ }^{378}$ Ibidem. p. 143.

${ }^{379}$ Márcio BENCHIMOL. Op. Cit. pp.67-68.
} 
têm coloração, causalidade e velocidade completamente diversas ${ }^{380}$. A primeira força ordena e subjuga o dionisíaco, pertencente à massa dos instintos. O contemplar apolíneo eleva o homem, preserva sua individualidade e dela necessita. No outro extremo está o sentir, que faz o indivíduo aproximar-se do desmedido e subterrâneo, que aniquila a individualidade ${ }^{381}$.

${ }^{380}$ Friedrich NIETZSCHE. Op. Cit..p.45.

${ }^{381}$ Márcio BENCHIMOL. Op. Cit.. pp.67-68. 


\section{A leitura de $O$ Nascimento da Tragédia neste trabalho}

"(...) o que nos importa não é (só) o que Nietzsche pensou ou (apenas) o que nós podemos pensar sobre Nietzsche, mas o que com Nietzsche, contra Nietzsche ou a partir de Nietzsche possamos (ser capazes ainda de) pensar." 382

Jorge Larrosa

Temos no deus do oráculo os desígnios mais evidentes adotados neste trabalho. Nietzsche mostra a ligação: Apolo reuniria em si "ao lado da necessidade estética da beleza, a exigência do 'conhece-te a ti mesmo" ${ }^{383}$. A justa medida, tal como a sentença anterior fruto do logos, está na outra frase do templo de Delfos: Ne quid nimis ${ }^{384}$.

Ambas as sentenças estão presentes no trabalho como títulos; é evidente o aspecto apolíneo que o trabalho parece materializar ao também tentar alcançar a bela aparência. Porém, a manifestação do oráculo não se dá pela clareza, mas sim pelo delírio. Nele se encontram as duas essências. Tanto no Nascimento da Tragédia quanto no presente trabalho. A aparência e a beleza tentam tocar seus limites, procura-se através delas o excesso. Reúnem-se os dois extremos no objeto artístico.

Todas as polaridades presentes na obra de Nietzsche parecem continuamente comportar-se de forma especular : beleza e dor; Apolo e Dioniso; conhecimento e experiência; logos e pathos; o véu da bela aparência da arte que encobre o irrazoável mas que, sem vencê-lo, é por ele parcialmente rasgado; o oráculo de Apolo e sua admoestação socrática do Conhece-te a ti mesmo manifestando-se de forma obscura e delirante.

\footnotetext{
${ }^{382}$ Jorge LARROSA. Nietzsche e a Educação. p.08.

${ }^{383}$ Friedrich NIETZSCHE. Op. Cit, p.40.

${ }^{384}$ Nada em demasia.
} 
A visão grega da condição humana é pessimista; a vida é miséria,dor e sofrimento que podem ser encobertos e tolerados pelo ocultamento operado pela arte. Da mesma forma, o homem percebido por Nietzsche encarna a dissonância: "(...) e que outra coisa é o homem? - esta dissonância, para poder viver, terá necessidade de uma magnífica ilusão que cubra sua essência com um véu de beleza" ${ }^{385}$.

Esta é uma questão de $O$ Nascimento da Tragédia que se confirma na beleza deliberadamente elaborada no oráculo: para suportar-se a dor da revelação do nada contida principalmente na sentença de Terêncio é preciso conceber essa dor como representação, como objeto de contemplação. A dor em si não pode ser embelezada, é a representação que ao envolvê-la em beleza, abranda-a ${ }^{386}$.

Uma das interpretações para a frase de Terêncio oferecida pela maioria dos oráculos do Conhece-te a ti mesmo: "sou homem; nada do que é humano me é estranho", é a de unidade de todos os indivíduos, de pertencermos todos a uma mesma origem e possuirmos uma mesma essência. O sentido descrito dessa concepção aproxima-se de pelo menos um dos possíveis sentidos da frase de Empédocles que diz: "tudo o que vive é um" ${ }^{387}$.

\footnotetext{
${ }^{385}$ Friedrich NIETZSCHE. Op. Cit.p.40.

${ }^{386}$ José Luiz FURTADO. Op. Cit. p.16.

${ }^{387}$ Márcio BENCHIMOL. Op. Cit. p.38. Ver epígrafe deste capítulo. Foi a partir de Pitágoras e Empédocles e da antiga idéia da unidade de tudo o que vive de Heráclito que Nietzsche construiu seu conceito de Uno-primordial.
} 


\section{Aparência}

A concepção de beleza de Nietzsche engloba conceitos da aparência ${ }^{388}$, dos efeitos que causa, da idéia de beleza da qual é herdeira e de seu antagonismo com a idéia socrática que alia o belo ao inteligível e à razão.

A beleza aparente não é a finalidade dos objetos do Conhece-te a ti mesmo, mas chave de acesso à leitura. A beleza sensível nos objetos aproxima-se da definição de véu: revela e oculta. Abre-se à contemplação e oculta o proferido pelo oráculo.

O sentido primeiro da palavra "aparência" conota a configuração exterior de algo; aquilo que se mostra imediatamente ou inclusive exterioridade enganosa, ilusão ${ }^{389}$. Aparência é tudo o que se dá a ver ou a sentir pelos sentidos ou pela consciência, logo um conceito com forte conotação empírica. Sua conotação pejorativa ou não provém da relevância que se dá à atuação dos sentidos ${ }^{390}$.

Na arte contemporânea a aparência de uma obra de arte e o papel que desempenha na relação com o espectador é definida por Plaza:

"a aparência como qualidade da arte é mero sentimento imediato entre o objeto e o sujeito, que se resolve e se confunde com as qualidades do objeto tal como está representado e com a substância da qual a obra de arte é feita" ${ }^{391}$.

No texto Tentativa de Autocrítica posterior ao Nascimento da Tragédia, ao discorrer sobre a moral do cristianismo, que tem "hostilidade à vida", Nietzsche afirma que aquela coloca lado a lado "aparência, ilusão,erro, interpretação, acomodamento, arte". Para o autor, em sua antimoral, a única redenção e remissão para o homem

\footnotetext{
${ }^{388}$ Schein, em alemão, significa "aparência". Assume várias conotações na estética, positivas ou negativas, conforme a época. Importante para a contemplação, segundo Schiller e a estética romântica, pejorativa para a metafísica kantiana, descrita pelo filósofo como uma experiência empírica ilusória. Cf. André COMTE-SPONVILLE. Dicionário Filosófico. pp.51-52.. Em O Nascimento da Tragédia a bela aparência da arte torna a vida suportável para o homem.

${ }_{389}$ Antonio HOUAISS. Dicionário Houaiss da Língua Portuguesa. p. 247.

390 André COMTE-SPONVILLE. Dicionário Filosófico. pp.51-52.

391 Julio PLAZA,A Arte da Tradução Intersemiótica,texto inédito.
} 
contraditório que sofre é a aparência dada pela arte, apesar da interpretação e significação morais da existência ${ }^{392}$.

${ }^{392}$ Friedrich NIETZSCHE,Op. Cit . p.19. 


\section{A noção de aparência em $O$ Nascimento da Tragédia.}

A primeira sensação de aparência provém dos sonhos. O mundo onírico é percebido como uma realidade subjacente que exerce influência no homem e, portanto, real e necessária ${ }^{393}$.

A sensação de aparência expande-se para a realidade na qual vivemos, pois sob esta também se esconde uma realidade subjacente, nós mesmos somos também aparência em relação "àquele fundo misterioso de nosso ser" ${ }^{394}$. Apolo começa por se situar no mundo da aparência para os gregos como deus divinatório, expressando a experiência onírica ${ }^{395}$. Num segundo momento, a idéia de aparência manifesta-se no "mundo interior da fantasia", num estado superior e perfeito em relação à realidade cotidiana $^{396}$.

Até este momento temos dois tipos de aparência sem a intencionalidade do criador. Até aqui os "impulsos artísticos da natureza" se manifestam nos sonhos e na "realidade inebriante". Percebe-se nesse termo a presença de Dioniso, estabelecendo-se assim a polaridade/complementaridade dos dois deuses. São estados artísticos da natureza, nela presentes, "onipotentes" e que guardam "um poderoso anelo para a aparência" $^{397}$.

A aparência envolve e é sentida como realidade empírica, pois, ao contrário do usual, Nietzsche sustenta a valoração da metade sonhadora da vida em relação de superioridade à outra metade comumente mais considerada, a desperta ${ }^{398}$.

\footnotetext{
393 Ibidem. p. 28.

394 Ibidem. p.39.

395 Ibidem. p.39.

396 Ibidem. p.29.

397 Ibidem.. p.32.

398 Ibidem.. p.32.
} 
A primeira é sentida pelo homem como constante redenção necessária, através da visão extasiante, da aparência pazerosa, existindo como necessidade. O filósofo conclui que a existência empírica e o mundo em geral são sentidos como representação, aparência $^{399}$.

Surge então o modo simbólico do homem de satisfazer a necessidade de aparência e beleza. A capacidade simbólica é usada pelo homem, deste momento em diante, para expressar a essência da natureza. O que incita ao máximo essa capacidade são os ritos dionisíacos. O impulso para a arte é dionisíaco, assim como o anseio pela beleza, pelos afetos e pela sensualidade. Os gregos criam então a teogonia, símbolo da vida e de seus sofrimentos, na qual puderam contemplar-se a si próprios numa esfera superior, a beleza ${ }^{400}$.

O artístico é visto como a "realidade do sonho", a "aparência da aparência". É visto com prazer. A partir das imagens tanto agradáveis quanto sombrias da criação, os gregos interpretaram a vida e exercitaram-se para ela ${ }^{401}$.

No mundo da aparência, Apolo e Dioniso combinam-se: as idéias que ambos representam mostram o eterno prazer da existência "uma pelas aparências, a outra por trás delas", pois temos por um lado a contemplação da imagem de natureza apolínea, cuja precondição é a bela aparência e, por outro, o prazer decorrente da aparência e da visão que compraz-se no aniquilamento do mundo da aparência visível ${ }^{402}$.

\footnotetext{
${ }^{399}$ Ibidem. p.39.

${ }^{400}$ Ibidem. p.35-38.

401 Ibidem. p. 29.

${ }^{402}$ Ibidem. p.101-102.
} 


\section{A noção de beleza em $O$ Nascimento da Tragédia}

Em todo o livro a palavra beleza encontra-se associada ao prazer sentido na aparência visual $^{403}$. Nietzsche não desenvolve a beleza como conceito estético; seu ponto de vista sobre o significado e importância da beleza alterna-se conforme a associação que faz com os princípios do apolíneo ou do dionisíaco.

Sendo a beleza um dos objetos de ódio da moral cristã, ela é de início como que recuperada como valor em si ${ }^{404}$. Sua principal definição é a de véu que, ao encobrir a verdadeira essência do homem e do mundo, e justamente por isso, o impele a prosseguir vivendo ${ }^{405}$.

A idéia de beleza é predominantemente associada a Apolo, porém na Tentativa de Autocrítica, ao escrever sobre a "questão fundamental" da relação dos gregos com a dor, antes da criação simbólica da teogonia olímpica, Nietzsche vê, lado a lado, dois anseios com a mesma origem comum dionisíaca: o anseio de beleza e o anseio do feio.

O primeiro traduz-se no desejo por festas, divertimentos, novos cultos. $\mathrm{O}$ anseio de beleza nasce paradoxalmente da privação, da melancolia, da dor. O anseio do feio é o desejo pelo pessimismo, pelo mito trágico, pela imagem do que é terrível, maligno, enigmático e aniquilador no fundo da existência. A combinação de ambos e a necessidade de criação que o último provoca foi o que permitiu o surgimento da arte ${ }^{406}$.

Num segundo momento vemos o impulso da beleza assumir uma condição apolínea - "como rosas a desabrochar da moita espinhosa". Simboliza assim o autor a criação da "teogonia do júbilo", que transcende por meio da beleza e da estetização da

\footnotetext{
${ }^{403}$ Ibidem. p. 80.

${ }^{404}$ Ibidem. p. 19.

405 Ibidem.p. 143.

${ }^{406}$ Ibidem.p. 17.
} 
vida a trágica condição humana de dor. A teogonia nasce exatamente desta raiz de sofrimento como meio simbólico de estetizar a dor da vida e transcendê-la, festejá-la ${ }^{407}$.

A respeito da criação artística, o filósofo localiza a presença do belo na arte do artista plástico. Seu alvo, no momento em que o sofrimento do indivíduo subjuga Apolo, é a glorificação luminosa da eternidade da aparência, na qual a beleza triunfa sobre o sofrimento inerente à vida, através de um apagamento "mentiroso" dos traços da natureza. Na obra de arte existe também o prazer da existência dionisíaco, mas este deve ser procurado por trás da aparência ${ }^{408}$.

Numa passagem da obra temos que o princípio apolíneo sempre presente no indivíduo satisfaz-lhe o senso de beleza "sedento de grandes e sublimes formas" 409 . Pense-se na conotação da palavra "sublime", conceito usado por Kant na estética que supera a noção do belo visual agradável, que abrange as noções de grande e terrível, que inclui uma forte participação dos sentimentos, mais até do que a visualidade ${ }^{410}$ e se terá uma ampliação da idéia de beleza apolínea, assumindo características antes mais próximas de Dioniso. Os domínios dos dois deuses não têm fronteiras intransponíveis.

Em relação à beleza, a maior crítica de Nietzsche é a respeito do papel subordinado à razão que lhe é destinado, a partir do fim da tragédia grega até a modernidade. Ele critica tanto a subordinação da beleza à razão quanto a subordinação da criação artística à postura crítica, o que chama de "estética racionalista" ou "socratismo estético". Para o filósofo a tragédia é irracional e opõe-se à metafísica, pois nesta última prevalece a verdade em detrimento da ilusão, apresenta como opostos a essência e a aparência ${ }^{411}$.

\footnotetext{
${ }^{407}$ Ibidem.pp.37-38.

${ }^{408}$ Ibidem. p. 102.

${ }^{408}$ Ibidem. p. 127.

${ }^{409}$ Immanuel KANT,Osservazioni sul Sentimento del Bello e del Sublime,p.28.

${ }^{410}$ Roberto MACHADO. Op. Cit. p.137.

${ }^{411}$ Friedrich NIETZSCHE. Op. Cit .p.81-83.
} 
O conceito de beleza nietzscheano afasta-se decididamente, portanto, dos motes socráticos de que "tudo deve ser inteligível para ser belo", "tudo deve ser consciente para ser belo" e "tudo deve ser consciente para ser bom" ${ }^{412}$.

O ponto no qual encontram-se o Nascimento da Tragédia e o Conhece-te a ti mesmo é o de uma beleza que prescinde do inteligível, do pensamento conceitual, afastando-se assim esta poética de uma das características mais fortes da beleza contemporânea descrita por Gadamer. Este autor assinala que enquanto o mundo grego via a manifestação do divino na arte, esta integrava-se num contexto que a justificava, do qual faziam parte a sociedade e a "autoconsciência do artista criador". Em tal contexto a arte era compreensível por si própria $^{413}$. A partir do século XIX modifica-se da contemplação intuitiva da arte, que torna-se um trabalho de elaboração ativa ${ }^{414}$, tornando-se a arte, hoje, "tarefa para reflexão" ${ }^{415}$.

\footnotetext{
${ }^{413}$ Hans-Georg GADAMER. A Atualidade do Belo. pp.15-16.

${ }^{414}$ É a mudança percebida por Hegel na arte do século XIX, quando "a arte não mais se deixa compreender por si mesma". Cf. Ibidem. p.18.

${ }^{415}$ Evidentemente essa mudança relaciona-se com as mudanças sofridas também pela disponibilidade do espectador em relação à assimilação da obra. Cf. Ibidem. p.20.
} 


\section{Conhece-te a ti mesmo ou Torna-te aquilo que és?}

O Nascimento da Tragédia adota a visão grega de que a arte justifica a vida, constitui um todo que não separa o inteligível do sensível - a crítica nietzscheana à metafísica - colocando o homem na realidade sensível, a única a poder ser chamada de realidade para o filósofo ${ }^{416}$. Desta maneira fica em segundo plano a importância que se poderia dar ao pensamento abstrato, teórico e filosófico que corrige a praxis ${ }^{417}$, identificado com Sócrates.

Nietzsche admira Heráclito e aproxima-se de sua doutrina ${ }^{418}$ em vários momentos. Um deles, a justificação estética da existência manifesta-se num dos principais pontos de $O$ Nascimento da Tragédia ${ }^{419}$. Em outro momento transparece a idéia heraclitiana da unidade de todas as coisas ${ }^{420}$ na noção do Uno-primordial e, por último, provém de Heráclito a rejeição da identidade do racional com o real ${ }^{421}$,crítica que Nietzsche prolonga a Sócrates.

No Nascimento da Tragédia o saber socrático representa um terceiro elemento cultural que desequilibra a convivência entre Apolo e Dioniso. Seria uma tendência não artística que privilegia a consciência, a razão, o pensamento lógico-racional, a dialética.

A idéia de que tudo deve ser consciente para que seja bom e belo faz parte do teatro de Eurípedes e constitui, para Nietzsche, o elemento assassino da tragédia e responsável pela decadência da cultura grega, exercendo seu domínio até na

\footnotetext{
${ }^{416}$ Richard BEARDSWORTH. Op. Cit .p.40.

${ }^{417}$ José Luiz FURTADO. Op. Cit.p.10.

${ }^{418}$ Segundo Heráclito há um único princípio unificador de todas as coisas e unificador dos opostos, o logos. Contrariamente às definições de um logos racional até o momento encontradas, em Heráclito esse princípio convive com a doutrina do "fluxo" de todas as coisas. Segundo a idéia do fluxo não se pode entrar duas vezes nas águas de um mesmo rio, porque novas águas estão sempre fluindo. As implicações dessa doutrina chegam à impossibilidade de categorizar verdadeiramente as coisas. (Heráclito de Éfeso. Morte após 480 a.C.)Cf. Simon BLACKBURN. Dicionário Oxford de Filosofia. pp. 180-181.

${ }^{419}$ Márcio BENCHIMOL. Op. Cit. p.49.

${ }^{420} \mathrm{~A}$ unidade do devir, que não se opõe à multiplicidade. Cf. Márcio BENCHIMOL. Op. Cit. p.48. Ver também nota 79, sobre a unidade de todas as coisas.

${ }^{421}$ Márcio BENCHIMOL. Op. Cit. p.51.
} 
modernidade ${ }^{422}$, pois, para o filósofo, a conseqüência da alta valorização da consciência é a inibição do inconsciente criativo ${ }^{423}$. Segundo Nietzsche o saber socrático racionalista afasta-se das profundezas do ser, domina instintos e paixões e aparta-se do mistério, cuja força encontra-se na escuridão. E é justamente das profundezas que provêem, para Nietzsche, o mito, a religião e a arte ${ }^{424}$.

${ }^{422}$ Márcio BENCHIMOL. Op. Cit. pp.117-118.

${ }^{423}$ Rüdiger SAFRANSKI. Op. Cit. p.54.

${ }^{424}$ Ibidem. p.55. 


\section{Conhecimento e autoconhecimento para Sócrates e Nietzsche}

Conhecer, para Sócrates, consistia essencialmente em trazer à luz a própria ignorância sobre o que supostamente se sabe por meio do método dialético ${ }^{425}$. Para Sócrates, nas palavras de Nietzsche, o saber possuiria "força curativa universal", seria o triunfo sobre o medo e o horror da morte ${ }^{426}$.

Sócrates reivindica conhecer e corrigir o ser por meio do saber e do conhecimento que atingem a verdade. $\mathrm{O}$ autoconhecimento nesse contexto é a experiência de si próprio, é "o espírito consciente de si" 427.

Já para Nietzsche o conhecimento não é a busca de uma verdade objetiva, mas é a permissão para a manifestação dos impulsos como forças interpretativas a partir de perspectivas diversas. Desse modo, conhecer é interpretar ${ }^{428}$.

A consciência, para Nietzsche, forma-se do acúmulo de acontecimentos. É um processo de transformação do indivíduo semelhante à idéia do rio de Heráclito que nunca permanece o mesmo e, portanto, não pode conhecer-se no sentido socrático ${ }^{429}$.

Enquanto que o Conhece-te a ti mesmo, divisa de toda a filosofia socrática, traduz-se no sujeito que, tendo a consciência e a introspecção como instrumentos debruça-se sobre si e conhece-se, para Nietzsche conhecer-se não é possível.

Torna-te aquilo que és, o mote nietzscheano, prescinde do conhecimento racional para a compreensão da existência. É uma atitude afirmativa da condição fisiológica se revelando. Para Nietzsche existir não se reduz a conhecer ${ }^{430}$.

\footnotetext{
${ }^{425}$ Sócrates servia-se do método indutivo. A partir das induções comuns do cotidiano tentava alcançar e esclarecer definições de ética e problemas morais sem pretender, no entanto cristalizar um conhecimento definitivo ou reduzir o pensar a um esquema teórico pré-concebido. É um método negativo, pois chega pelo questionamento do que se sabe a um não-saber, na tentativa de libertar o interlocutor do erro e do mal por meio da reflexão e da consciência. Cf. Andrea BIRAGHI. Op. Cit. p.21.

${ }^{426}$ Rüdiger SAFRANSKI. Op. Cit. p.263.

427 Ibidem. pp.131-132.

428 Sandro Kobol FORNAZARI.Op. Cit. p.113.

${ }^{429}$ Conceitos colhidos nas aulas de Scarlett Marton, FFLCH/USP, 2005.
} 
Porém, as imagens especulares que se multiplicam em $O$ Nascimento da Tragédia, a procurada solução dos dois princípios opostos de Apolo e Dioniso mediante a complementaridade não se poderiam esgotar ao chegar a vez de Sócrates e o racionalismo, já que é tão forte a presença deste nos desígnios de Apolo.

"No ato de conhecer, o ser humano se liga com o verdadeiro Ser, torna-se aquilo que já é. Ele volta para casa" ${ }^{431}$.

A frase é de Sócrates. Coincidentemente ambos os filósofos lutam para tornarem-se o que são por caminhos evidentemente opostos. Um, pela claridade da razão. O outro, pela obscuridade dionisíaca ${ }^{432}$.

\footnotetext{
${ }^{430}$ Conceitos colhidos nas aulas de Scarlett Marton, FFLCH/USP, 2005.

${ }^{431}$ Sócrates, Apud Rüdiger SAFRANSKI. Op. Cit. p.130.

${ }^{432}$ Ibidem. p. 130.
} 


\section{Nietzsche como regulador da poética?}

A herança de Sócrates no modo de pensar moderno é inegável. Revela-se inclusive na necessidade de elaboração de uma dissertação para um mestrado em Poéticas Visuais. Este trabalho, entretanto, não se propõe partidário de um ou outro tipo de saber, socrático-platônico ou dionisíaco. A escolha do título não indica uma opção filosófica, mas uma opção poética.

O contato do espectador com uma poética pode se dar por duas vias. Sob o signo de uma visão consciente e reflexiva, mas também por meio do impacto emocional. O alcance da compreensão desse mesmo espectador é também limitado pela própria natureza da arte, que guarda em si um núcleo intocado e escuro, mais profundo do que aquilo que pode ser verbalmente explicitado sobre ele.

Para o criador a situação apresenta-se de forma semelhante. É possível a reflexão posterior à criação de uma obra e até mesmo antes e durante sua elaboração. Mas seu processo criativo nunca poderá ser completamente desvendado.

A metáfora do oráculo propõe o que toda obra propõe. Transformação. Que não se dá apenas por uma via, seja pela análise distanciada da reflexão ou pelo impacto inexplicável do contato com o sensível. Mas se de fato houver uma experiência significativa no contato com a obra de arte, de fato ocorre a modificação do espectador. Novamente Apolo e Dioniso complementam-se na leitura contemporânea deste trabalho.

Dezesseis anos depois de $O$ Nascimento da Tragédia,Nietzsche refere-se ao artista (os atores) como alguém que ensina o homem a ver-se à distância. Contudo, não como de fato esse seja, mas transfigurado. $\mathrm{O}$ artista teria a capacidade de ensinar ao homem a arte de ver a si mesmo como herói ${ }^{433}$. Num certo sentido o artista consegue fazer com que o espectador, observando a si próprio à distância, se transfigure.

${ }^{433}$ Friedrich NIETZSCHE. A Gaia Ciência. Aforismo 78. p. 186. 
Para Nietzsche a metáfora é um fenômeno estético, surgido originariamente na arte. É forma cujo resíduo só depois se torna conceito. Só depois, portanto, assume o sentido de deslocamento e transposição ${ }^{434}$.

No pouco que permite ver, apenas pelo vislumbre, o véu possibilita suportar a resposta. $\mathrm{O}$ véu de beleza só permite a visão justamente porque a esconde.A palavra não é a razão equilibrada e esclarecedora; ao contrário, reproduz o mistério e a impenetrabilidade da dúbia resposta oracular; é mais um dado para a interpretação e não uma legenda esclarecedora.

Há um autoconhecimento possível que relaciona obra de arte e espectador que é a experiência significativa que modifica o espectador, que mediante o contato com a obra de arte consegue olhar para si e formar novamente a si próprio.

${ }^{434}$ Eric BLONDEL. Nietzsche: A Vida e A Metáfora. Cadernos Nietzsche n ${ }^{o} 16$. pp.34-35. 
Conclusão

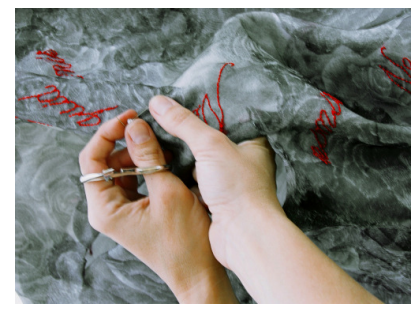




\section{Conclusão}

"Pois a resposta que forjamos para nós mesmos seguramente não deixa de ser a própria questão; e toda questão do espírito ao próprio espírito não é, e não pode ser, senão

Paul Valéry

Debruçar-se sobre si, e apenas sobre si, sem um contraponto, um interlocutor, é tautológico. A dialética socrática, que é também um instrumento para a recepção na arte, confirma a necessidade do outro para se atingir seja o conhecimento, ou alguma forma de autoconhecimento, ou o efeito estético.

A obra de arte pode ser este interlocutor para o espectador, como propõe a metáfora do oráculo e como afirma Gadamer, quando diz que através da arte "aprendemos a compreender-nos a nós próprios (...), superamos a descontinuidade e a contingência da Erlebnis através da continuidade da nossa existência" ${ }^{436}$.

Completar um mestrado também significa para o artista a possibilidade de tornar-se por sua vez interlocutor no aprendizado de outros artistas, pois toda situação de aprendizado necessita de um contraponto para se desenvolver. Neste contexto novamente se evidencia a importância da capacidade de análise proporcionada pela reflexão sobre o processo criativo e os métodos heurísticos de criação.

Esta dissertação não pretende postular a possibilidade ou a impossibilidade absolutas do autoconhecimento por meio da arte para o espectador e para o artista, seja no sentido estético ou humano. Pretende sim metaforizar uma possível relação com a obra de arte que consiga despertar no espectador a indagação sobre o que o leva a dela se aproximar, do quanto de si nela encontra e a ele retorna como se fosse novo.

\footnotetext{
${ }^{435}$ Paul VALÉRY. Eupalinos ou O Arquiteto. p. 167.

${ }^{436}$ Gianni CARCHIA e Paolo D'ANGELO. Dicionário de Estética.
} 
Os oráculos são objetos que se oferecem à experiência sensível. Seus efeitos, porém, escapam ao controle e às expectativas do momento da criação. Podem assumir vários níveis de significação para o espectador, tanto próximos quanto distantes dos planejados. Tais efeitos independem do discurso teórico construído em torno do trabalho.

O oráculo como metáfora da recepção não é uma condição pré-estabelecida para que ocorra o efeito estético. É uma discussão relevante num contexto reflexivo, posterior ao desejado impacto sensível produzido pelo contato com a obra.

A obra de arte finalizada também pode ser interlocutor para o autoconhecimento do próprio artista enquanto criador, quando este revê seu processo, reflete sobre ele, reorganiza procedimentos e muda sua trajetória em função daquilo que aprendeu com seu próprio trabalho, entre outras fontes de reflexão. 
Bibliografia 


\section{Livros}

ARNHEIM, Rudolf. Arte e Percepção Visual, 2a ed.São Paulo: Pioneira/Edusp, 1980.

AUMONT, Jacques. A Imagem, $8^{\text {a }}$ ed. São Paulo: Papirus, 2004.

BARTHES, Roland. O Óbvio e o Obtuso. Rio de Janeiro: Nova Fronteira, 1990.

BAUDELAIRE, Charles. Sobre a Modernidade. São Paulo: Paz e Terra, 1996.

BEARDSWORTH, Richard. Nietzsche.S.Paulo: Estação Liberdade, 2003.

BELLUZZO, Ana Maria. Carmela Gross. S.Paulo: Cosac \& Naify, 2001.

BENCHIMOL, Márcio. Apolo e Dionísio. São Paulo: Annablume/Fapesp, 2002.

BODEI, Remo. As Formas da Beleza. Bauru: Edusc, 2005.

BUTOR, Michel. Les Mots Dans la Peinture.Genéve: Ed.d'art Albert Skira, 1969.

COLLI, Giorgio. Scritti su Nietzsche,2aed. Milano: Adelphi, 1986.

DELEUZE, Gilles. Proust e os Signos, $2^{\mathrm{a}}$ ed. Rio de Janeiro: Forense Universitária, 2003.

DERRIDA, Jacques e VATTIMO,Gianni (org.). La Religione. Roma: Laterza, 1993.

DORFLES, Gillo. Le Oscillazioni del Gusto,13ª ed. Torino: Einaudi, 1998.

DORFLES, Gillo. Elogio à Desarmonia. Lisboa: Ed.70, 1986.

DRUET, Roger e GRÉGOIRE, Herman. La Civilasation de L'ecriture. Paris: Fayard et Dessain et Tolra, 1976.

DUFRENNE, Mikel. A Estética e as Ciências da Arte. Lisboa: Bertrand, 1982.

ECO, Umberto. A Obra Aberta. São Paulo: Perspectiva, 1969.

ECO, Umberto. Como se Faz uma Tese, 19ªed. São Paulo: Perspectiva, 2004.

FERRARA, Lucrécia. A Estratégia dos Signos. São Paulo: Perspectiva, 1991.

FORNAZARI, Sandro Kobol. Sobre o Suposto Autor da Autobiografia de Nietzsche. São Paulo: Discurso Editorial, 2004.

FOUCAULT, Michel. Isto Não é um Cachimbo,2a ed. Rio de Janeiro: Paz e Terra, 1988.

FRAZIER, Nancy. Georgia O'Keeffee. New Jersey: Crescent Books, 1990.

ELTON, W.R. (org.). Estetica e Linguaggio. Roma: Armando Armando, 1977. 
GADAMER, Hans Georg. A Atualidade do Belo. Rio de Janeiro: Tempo Brasileiro, 1985.

HEGEL, Georg Wilhelm Friedrich. Cursos de Estética vols. I e II. São Paulo: Edusp, 2002.

HUGO, Victor. William Shakespeare. Londrina: Campanário, 2000.

HULME Thomas. Filosofia e Arte. Buenos Aires: Argos, 1949.

ISER, Wolfgang. O Ato da Leitura vols. I e II. São Paulo: Ed. 34, 1996/1999.

JIMENEZ, Marc. O que é Estética? São Leopoldo: Unisinos, 1999.

KANT, Immanuel. Osservazioni sul Sentimento del Bello e del Sublime. Milano: Rizzoli, 1989.

KAPR, Albert. The Art of Lettering. New York, London, Paris: Saur, 1983.

LACOSTE, Jean. A filosofia da Arte. Rio de Janeiro: Zahar, 1986.

LANGER, Susanne. Sentimento e Forma.São Paulo: Perspectiva, 1980.

LARROSA, Jorge. Nietzsche e a Educação.Belo Horizonte: Autêntica, 2002.

MACHADO, Roberto (org.) Nietzsche e a Polêmica sobre O Nascimento da Tragédia. Rio de Janeiro: Zahar, 2005.

MARIN, Louis. Sublime Poussin. São Paulo: Edusp, 2000.

MARQUES, Maria Eduarda. Mira Schendel.São Paulo: Cosac \& Naify, 2001.

NIETZSCHE, Friedrich. Ecce Homo. S.Paulo: Cia.das Letras, 1992.

NIETZSCHE, Friedrich. Humano, Demasiado Humano.S.Paulo: Cia.das Letras, 1992.

NIETZSCHE, Friedrich. O Nascimento da Tragédia $2^{\mathrm{a}}$ ed. S.Paulo: Cia. das Letras, 1992.

NOVAES, Adauto (org.). Artepensamento. S.Paulo: Cia das Letras, 1994.

OSBORNE, Harold. A Apreciação da Arte. São Paulo, Cultrix, 1978.

PANOFSKY, Erwin. Idea: A Evolução do Conceito de Belo. São Paulo: Martins Fontes, 2000.

PANOFSKY, Erwin. Significado nas Artes Visuais. São Paulo: Perspectiva, 2002.

PAREYSON, Luigi. Os Problemas da Estética, $3^{\mathrm{a} e d . . ~ S a ̃ o ~ P a u l o: ~ M a r t i n s ~ F o n t e s, ~} 2001$. 
PAREYSON, Luigi. Estética e Teoria da Formatividade. Rio de Janeiro: Vozes, 1993.

PEREIRA, Wilcon Joia. Escritema e Figuralidade. Assis: Faculdade de Filosofia, Ciências e Letras/Hucitec, 1976.

PHAIDON. Art Book. London: Phaidon, 1994.

PIMENTA NETO, O.J. e BARRENCHEA, M.A. (orgs.) Assim Falou Nietzsche. Rio de Janeiro: Sette Letras, 1990.

PLAZA, Julio e TAVARES, Mônica B. Processos Criativos com os Meios Eletrônicos : Poéticas Digitais. S.Paulo: Hucitec, 1998.

RICARDO, Cassiano. Poesias Completas. Rio de Janeiro: José Olympio, 1957.

SAFRANSKI, Rüdiger. Nietzsche.São Paulo: Geração Editorial, 2001.

SARTRE, Jean-Paul. O Imaginário. São Paulo: Ática, 1996.

SEVERINO, Antonio J. Metodologia do Trabalho Científico, 22 a ed. S.Paulo: Cortez, 2002.

STEINER, George. Nenhuma Paixão Desperdiçada. R.de Janeiro: Record, 2001.

TRISTAN Frederick. Les Tentations. Poitiers: Balland, Massin, 1981.

VALÉRY, Paul. Eupalinos ou O Arquiteto. S.Paulo: Ed.34, 1999.

VALÉRY, Paul. Introdução ao Método de Leonardo da Vinci. São Paulo: Ed. 34, 1998. VATTIMO, Gianni. O Fim da Modernidade. S.Paulo: Martins Fontes, 1996.

\section{Dicionários e Enciclopédias}

BIRAGHI, Andrea (org.). Dizionario di Filosofia. Milano: Ed. di Comunità, 1957.

BLACKBURN, Simon. Dicionário Oxford de Filosofia. Rio de Janeiro: Zahar, 1997.

BRANDÃO, Junito de Souza. Dicionário Mítico-etimológico da Mitologia Grega. Petrópolis: Vozes, 1991.

CARCHIA, Gianni e D'ANGELO, Paolo. Dicionário de Estética. Lisboa: Ed.70, 1999.

CHEVALIER, J. e GHEERBRANT, A. Dicionário de Símbolos.Rio de Janeiro: José Olympio, 1988. 
CHILVERS, I.; OSBORNE, H. e FARR, D. Diccionario de Arte. Madrid: Allianza Editorial, 1992.

COMTE-SPONVILLE, André. Dicionário Filosófico. São Paulo: Martins Fontes, 2003.

HALL, James. Dictionary of subjects \& Symbols in Art .New York: Harper and Row, 1979.

HOUAISS, Antônio; VILLAR, M. de S. e FRANCO, F.M. Dicionário Houaiss da

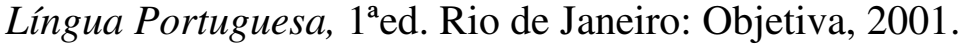

LAVEDAN, Pierre. Dictionnaire Illustré de la Mythologie et des Antiquités Grecques et Romaines.Paris: Hachette, 1931.

NOVA CULTURAL. Enciclopédia Larrousse Cultural. São Paulo: Nova Cultural, 1998.

\section{Artigos em revistas}

BLONDEL, Eric. Nietzsche: a Vida e a Metáfora. Cadernos Nietzsche,nº16, p.07-51, 2004.

DIAS FILHO, Geraldo de Souza. Contundência e Delicadeza na Obra de Mira Schendel. Ars. Revista do Departamento de Arte Plásticas, ECA/USP, ano 1, nº1, p.117-139, 2003.

PLAZA, Julio. Arte e Interatividade: autor-obra-recepção. ars. Revista do Departamento de Artes Plásticas, ECA/USP, ano 1, n²,p.9-29. 2003.

REY, Sandra. Da Prática à Teoria: Três Instâncias Metodológicas Sobre a Pesquisa em Poéticas Visuais. Porto Arte Revista de Artes Visuais, Instituto de Artes, UFRGS, Porto Alegre

REY, Sandra. Notas Sobre Metodologia em Artes Plásticas. In: ANPAP, Congresso Nacional de Pesquisadores em Artes Plásticas, vol.II. Anais, 22 a 26 out 1996. p.301309.

SILVEIRA, Regina. Produção Artística e Pesquisa: Situação Atual. In: ANPAP, Congresso Nacional de Pesquisadores em Artes Plásticas, vol.I, Anais, 22 a 26 out 1996.

TAVARES, Mônica B. Fundamentos Estéticos da Arte Aberta à Recepção. Ars, Revista do Departamento de Artes Plásticas, vol.I, n², p.31-44, 2003 
WEISS, Luise. Monotipia: Algumas Considerações. Cadernos de Gravura.n², p.16-20. nov.2003.

\section{Teses}

BARROS, Ana Maria de C., Luzgar: Lugar de Muy Vivir, 1990. Dissertação (mestrado em artes). ECA/USP, São Paulo.

CEZARETTI, Maria Elisa. Olhar em Suspensão: Giorgio Morandi e a Natureza-morta, 2002. Tese (doutorado em artes). ECA/USP, São Paulo.

MONSELL, Alice Jean. Corpos em Suspensão, 2000. Dissertação (mestrado em artes) UFRGS, Porto Alegre.

MUBARAC, Luiz Cláudio. Notas Sobre Incisão, 1998. Tese (doutorado em artes). ECA/USP, São Paulo.

NITSCHE, Maria do Carmo Gross. Projeto para a Construção de um Céu,1981. Dissertação (mestrado em artes), ECA/USP, São Paulo.

NITSCHE, Maria do Carmo Gross. Pintura/Desenho.Tese (doutorado em artes), ECA/USP, São Paulo.

ZAMBONI, Sílvio Perini. A Pesquisa em Arte, 1992. Tese (doutorado em artes) ECA?USP, São Paulo.

\section{Catálogos}

CHIOVATTO, Mila Milene. Sobre Camadas. São Paulo, Galeria SESC Paulista, 2001.

COCCHIARALE, Fernando. As Flores também Ficam Instáveis e Podem Ferir. Brasília, Arte 21, 2002.

FORTES, Márcia. Espelho Cego.São Paulo, MAM, 2001.

GLASER, Milton. Giorgio Morandi.Bologna, Galleria Comunale D'Arte Moderna. Mondadori, 1989.

LAGNADO, Lisette. São Tantas as Verdades, São Paulo, Galeria do SESI, 1995.

GALERIA CAMARGO VILAÇA.Ponto de fuga (Vanishing Point). São Paulo, individual de Waleska Soares, 1999. 
MASP. Morandi. São Paulo,1997.

\section{Inéditos}

DIAS FILHO, Geraldo de Souza. Escrita e imagem na pintura. Plano de Pesquisa. ECA/USP, 2002.

PLAZA, Julio. A Arte da Tradução Intrsemiótica.

\section{Documentos e dados da Internet}

NAVARRO, Heloisa. Monotipia. //br.geocities.com/heloisanavarro/Origem.htm. Acesso: agosto de 2006.

FITA DE MÖBIUS. //inorgan221.fq.unesp.br/quimgeral//moebius.htm/.Acesso: agosto de 2005. 


\section{Lista das ilustrações}

\section{Créditos das Imagens dos Trabalhos}

Rosa Maria Gonçalves e Mirella Amalia Mostoni

\section{Página 53}

Mira Schendel

Monotipias (série escuras), s/d

Monotipias sobre papel arroz, 42 x $63 \mathrm{~cm}$. cada

\section{Página 56}

Mirella Mostoni

Processo de elaboração de monotipias, 2005.

Créditos: Rosa Maria Gonçalves

\section{Página 58}

Mirella Mostoni

Sem título, 2001

Monotipia sobre organdi recortado e costurado, 11 x 36 x $41 \mathrm{~cm}$.

Créditos: Everton Ballardin

\section{Página 67}

Mirella Mostoni

Sem título, 1999

Monotipia sobre organdi recortado, $100 \times 120 \mathrm{~cm}$.

\section{Página 72}

Mirella Mostoni

Sem título, 2001

Monotipía sobre organdi recortado e costurado, 45 x $100 \mathrm{~cm}$.

\section{Página 81}

Mirella Mostoni

Oráculo Portátil, 2005

Bordado sobre tule, monotipia sobre organdi recortado e costurado, 9 x 30 x $38 \mathrm{~cm}$.

Créditos: Rosa Maria Gonçalves e Mirella Mostoni

\section{Página 82}

Mirella Mostoni

Oráculo Portátil, 2005

Bordado sobre tule, monotipia sobre organdi recortado e costurado, 6 x $43 \times 47 \mathrm{~cm}$.

Créditos: Rosa Maria Gonçalves e Mirella Mostoni

\section{Página 84}

Mirella Mostoni

Desenho de base para a elaboração das monotipias-rosas, 1999

Esferográfica sobre algodão, 80 x $80 \mathrm{~cm}$. 


\section{Página 86}

Mirella Mostoni

Desenho preparatório para as Fendas Oraculares, 2003

Hidrográfica sobre papel vegetal, 20 x $30 \mathrm{~cm}$.

\section{Página 86}

Georgia O'Keeffe

Jack-in-the-pulpit $n^{\circ} \mathrm{IV}, 1930$

óleo sobre tela, $102 \times 76 \mathrm{~cm}$.

\section{Página 100}

Pierre Didot

Alfabeto, 1798

\section{Página 101}

Le Mâitre à la Navette

Alegoria da Velhice e da Morte, século XVI

\section{Página 103}

Nicolas Poussin

Os Pastores da Arcádia, 1638-9

Óleo sobre tela, 85 x $121 \mathrm{~cm}$.

\section{Página 107}

Carmela Gross

Recorte Branco, 1988

Ferro e tecido recortado sobre madeira, $52 \times 21 \mathrm{~cm}$.

\section{Página 107}

Carmela Gross

Recortes Pretos, 1995

Ferro e tecido recortado, 197 x 179 x $10 \mathrm{~cm}$.

\section{Página 108}

Leonílson

Fertilidade, Coerência, Silêncio, 1991

Bordado sobre voile, $110 \mathrm{~cm}$.

\section{Página 108}

Mira Schendel

Sem título (trenzinho), década de 60

Folhas de papel arroz e fio de nylon, 45 x 65 x $15 \mathrm{~cm}$.

\section{Página 108}

Mirella Mostoni

Sem título, 1999

Monotipía sobre organdi recortado e costurado, 150 x $45 \mathrm{~cm}$. 


\section{Página 109}

Leda Catunda

Sete Véus, 1989

Acrílica sobre tecidos, 220 × $75 \mathrm{~cm}$.

\section{Página 109}

Waleska Soares

Sem título, 1999

\section{Página 109}

Waleska Soares

Sem título (Preserva), 1991

Rosas vermelhas e algodão, 30 x 70 cada

\section{Página 111}

Mirella Mostoni

Sem título, 1998

Monotipia sobre entretela de algodão, 23 x $26 \mathrm{~cm}$.

\section{Página 111}

Giorgio Morandi

Mó em Grizzana, 1929

Água-forte, 7 x 25,5 cm.

\section{Página 111}

Mirella Mostoni

Monotipia-rosa, s/d

Monotipia sobre organdi, 11 x $10 \mathrm{~cm}$.

\section{Página 112}

Giorgio Morandi

Zinnie in un Vaso, 1932

Água-forte, 20 x $19 \mathrm{~cm}$. 


\section{Agradecimentos}

A Geraldo de Souza Dias Filho, a Rosa Maria Gonçalves e a Antônio Henrique Sobrinho. 